
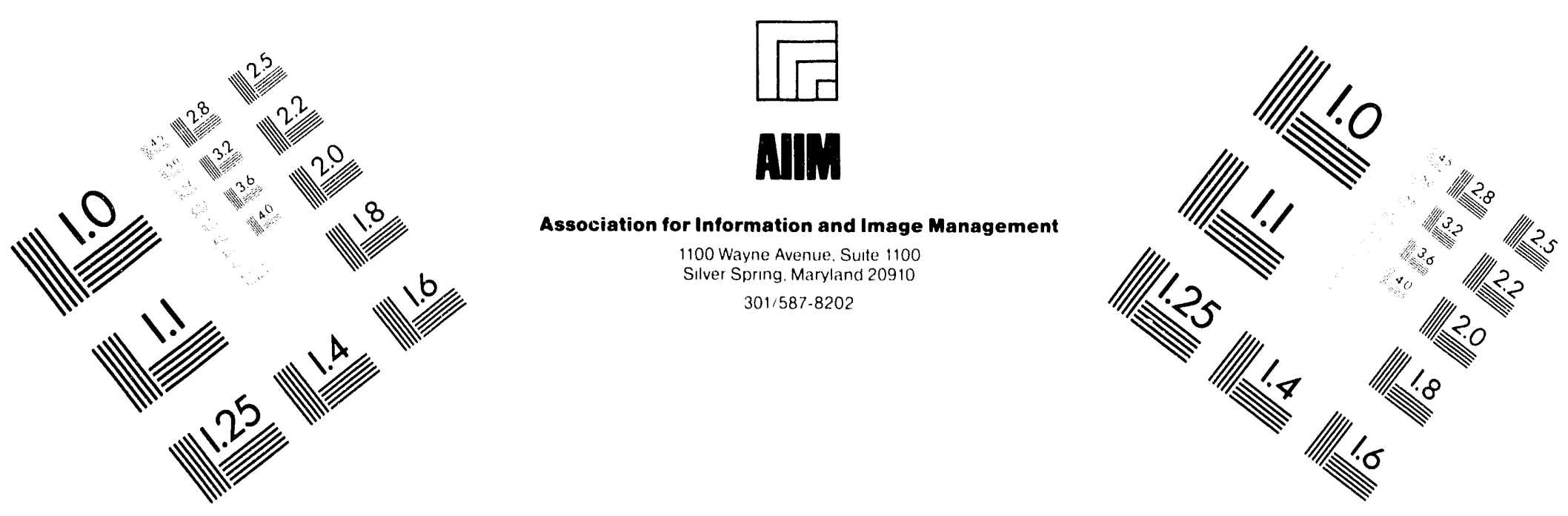

\title{
Centimeter
}

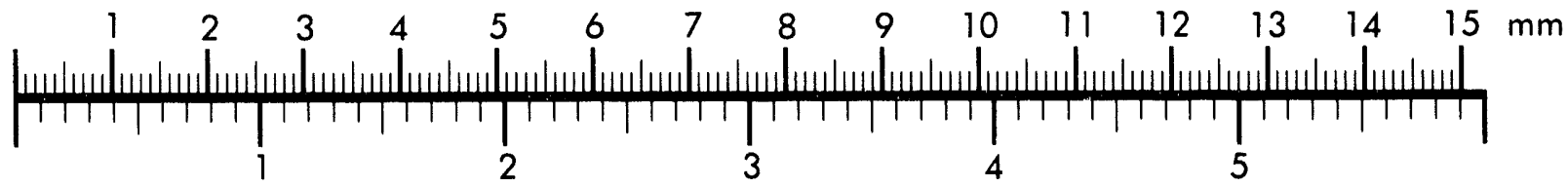
Inches
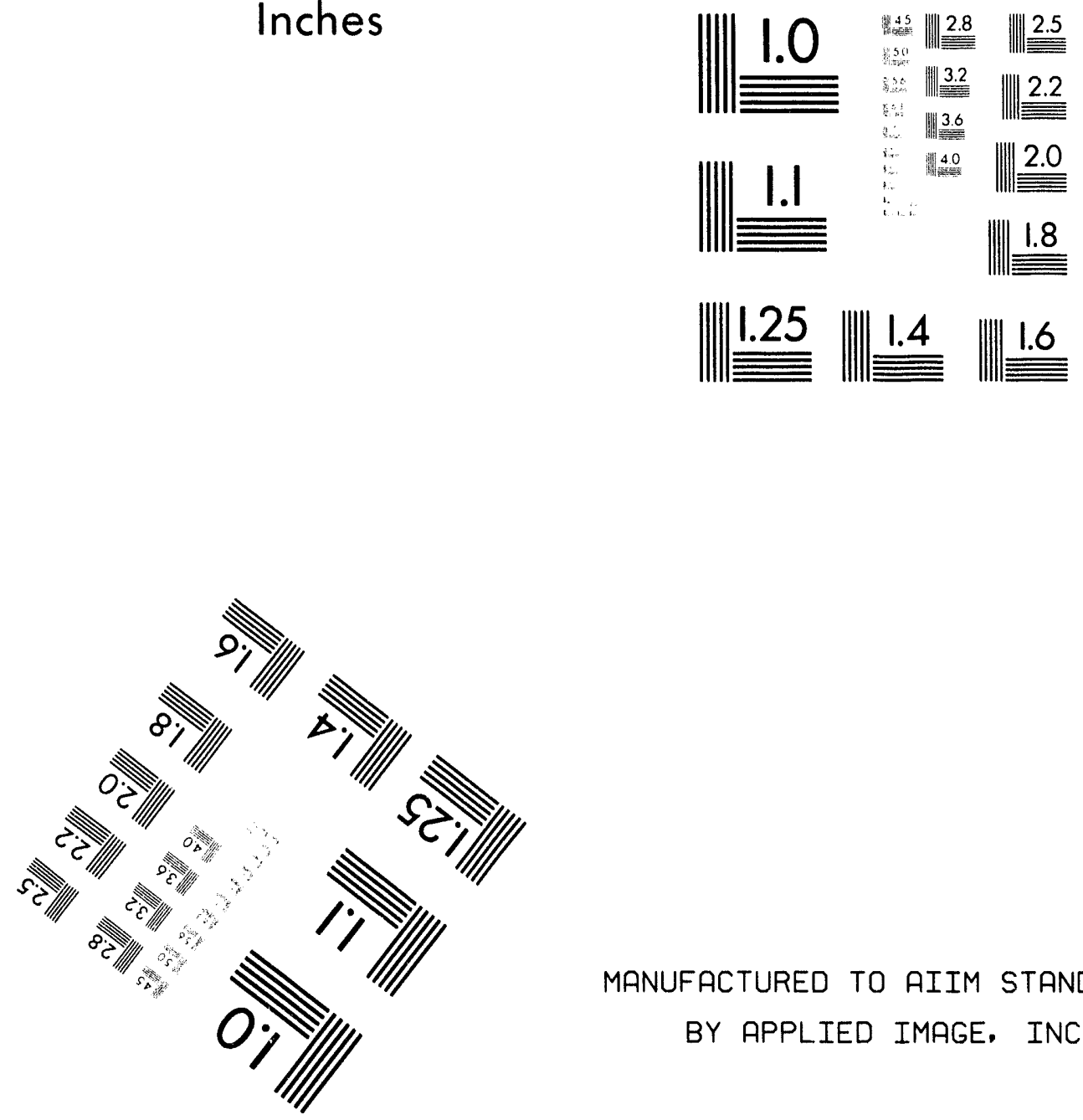

MANUFACTURED TO AIIM STANDARDS

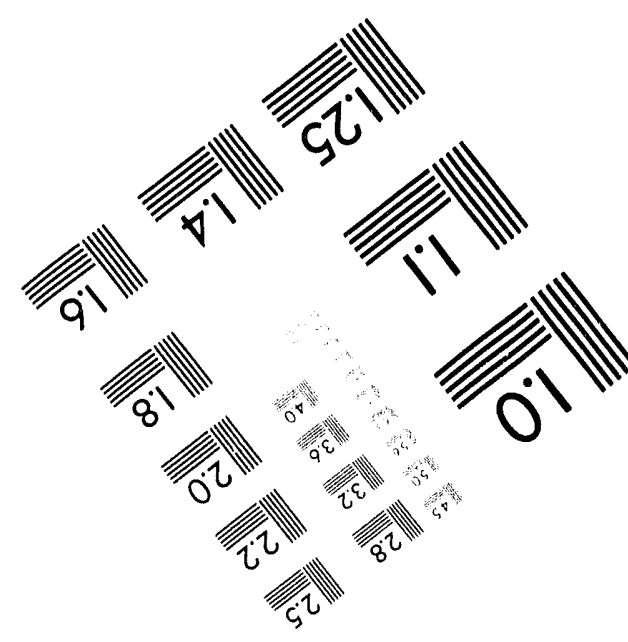



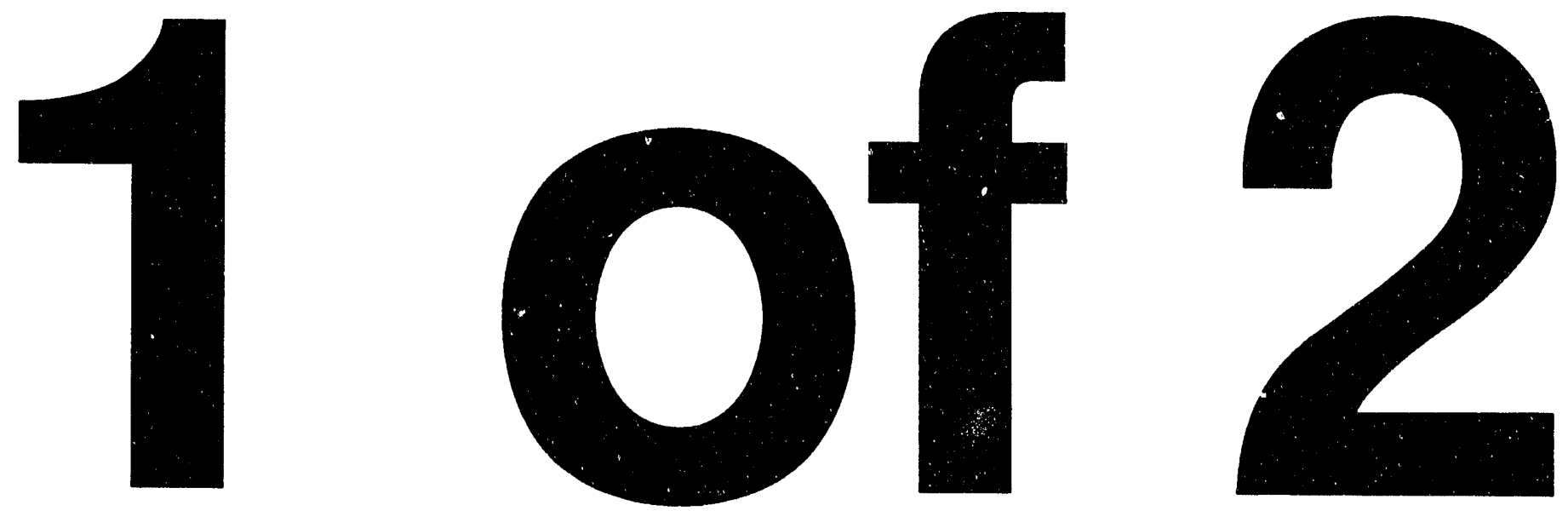


\section{Studies of Acute and Chronic Radiation Injury at the Biological and Medical Research Division, Argonne National Laboratory, 1953-1970: Description of Individual Studies, Data Files, Codes, and Summaries of Significant Findings}

by D. Giahn

with the technical assistance of

C. Fox, B.J. Wright, and B.A. Carnes

Center for Mechanistic Biology and Biotechnology

Argonne National Laboratory, 9700 South Cass Avenue, Argonne, Illinois 60439

May 1994

Work sponsored by the United States Department of Energy,

Office of Health and Environmental Research, under Contract No. W-31-109-Eng-38 
This report is printed on recycled paper. 


\section{CONTENTS}

FOREWORD $\ldots \ldots \ldots \ldots \ldots \ldots \ldots \ldots \ldots \ldots \ldots \ldots \ldots \ldots \ldots \ldots \ldots \ldots \ldots \ldots \ldots$

ACKNOWLEDGMENTS $\ldots \ldots \ldots \ldots \ldots \ldots \ldots \ldots \ldots \ldots \ldots$ viii

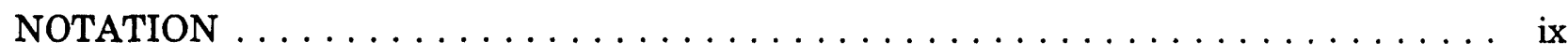

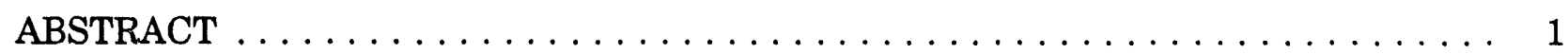

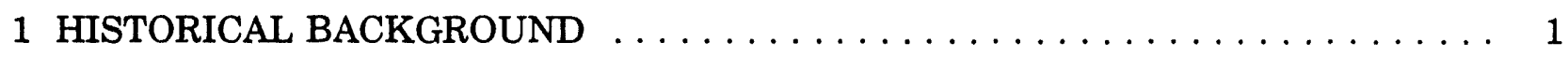

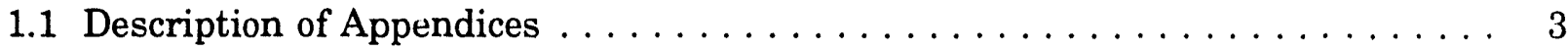

1.1.1 Appendix A: File Formats . . . . . . . . . . . . . . 3

1.1.2 Appendix B: Strain Codes, Strain Designations, and Brief Characteristics ....................... 4

1.1.3 Appendix C: Data Codes and Radiation Protocols ............ 4

2 NATIONAL CANCER INSTITUTE STUDIES, $1943-1953 \ldots \ldots \ldots \ldots \ldots \ldots$

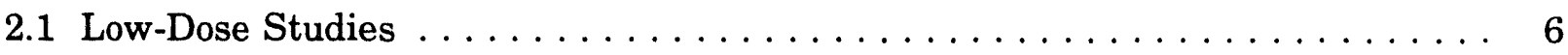

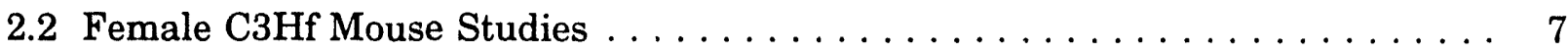

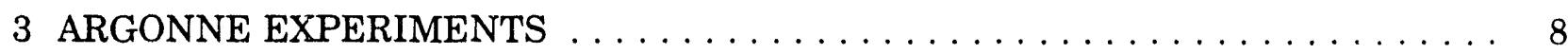

3.1 Experiment XAM-3 $\ldots \ldots \ldots \ldots \ldots \ldots \ldots \ldots \ldots \ldots \ldots \ldots \ldots \ldots$

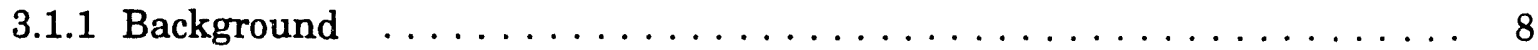

3.1.2 Experimental Design $\ldots \ldots \ldots \ldots \ldots \ldots \ldots \ldots \ldots \ldots \ldots \ldots$

3.1 .3 Data Recorded ........................... 11

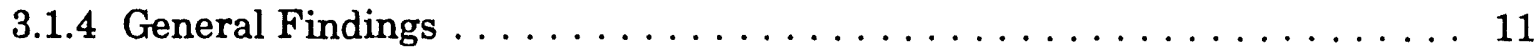

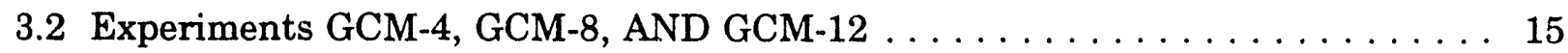

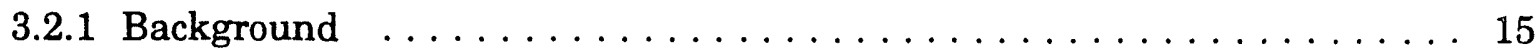

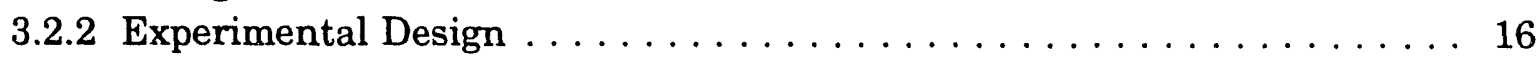

3.2 .3 Data Recorded ............................ 18

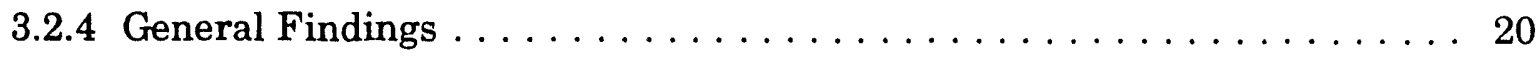

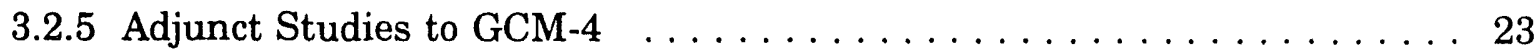

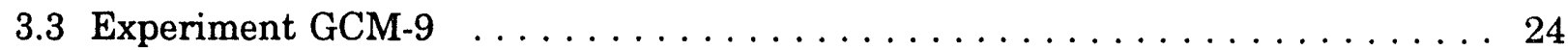

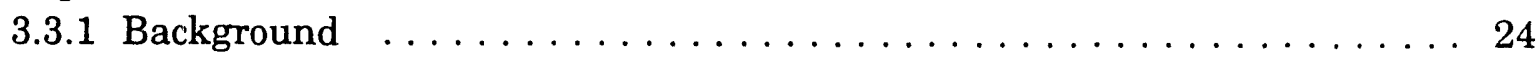

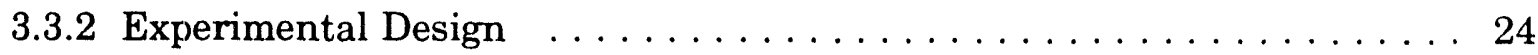

3.3.3 Data Recorded ........................... 25

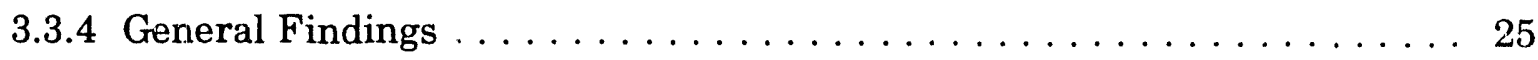

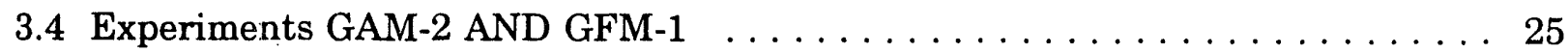

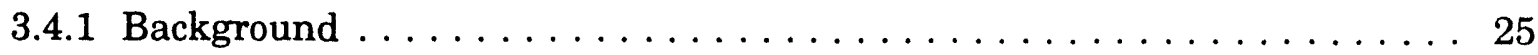

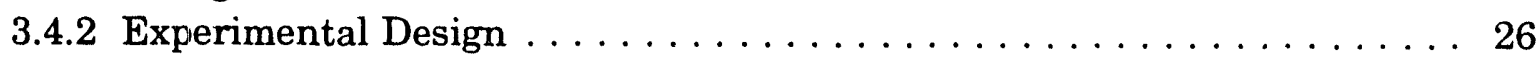




\section{CONTENTS (Cont.)}

3.4 .3 Data Recorded . . . . . . . . . . . . . . . . . . . 26

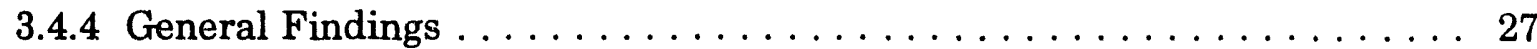

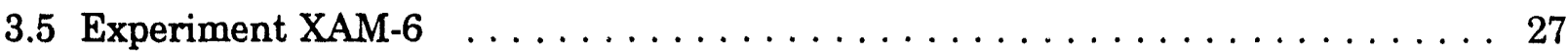

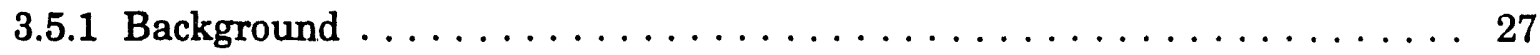

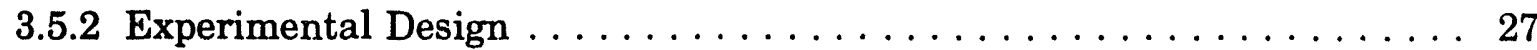

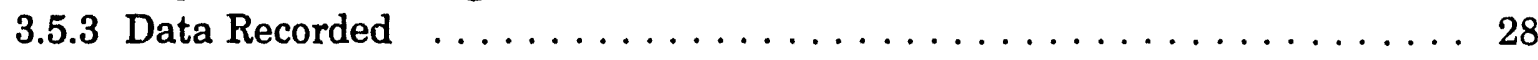

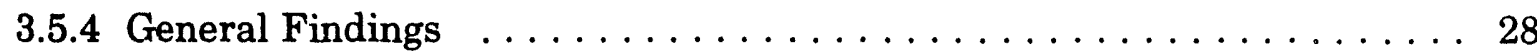

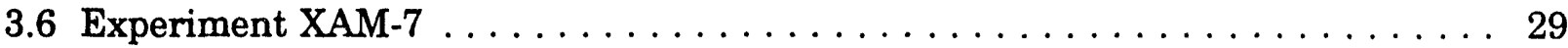

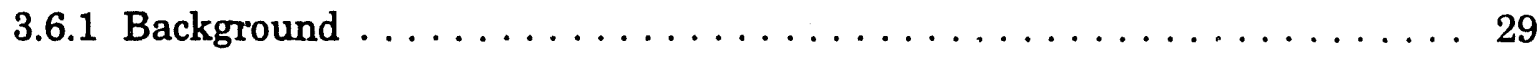

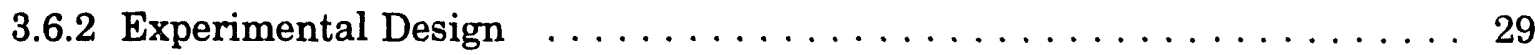

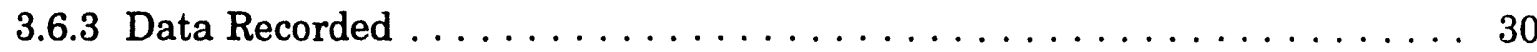

3.6.4 General Findings . . . . . . . . . . . . . . . . 30

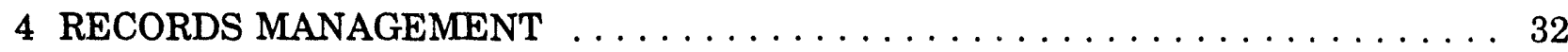

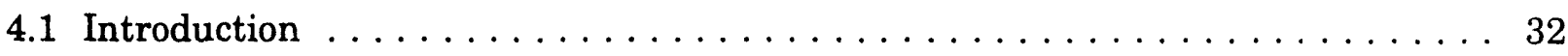

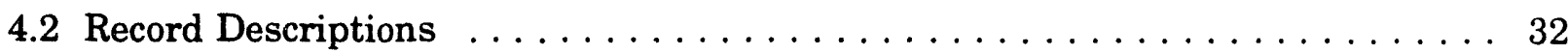

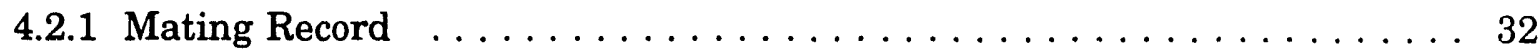

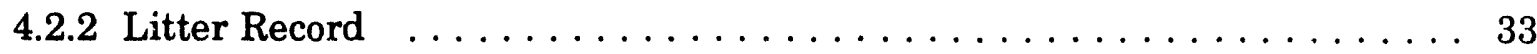

4.3 Pre-experimental Stock Cage Record $\ldots \ldots \ldots \ldots \ldots \ldots \ldots$

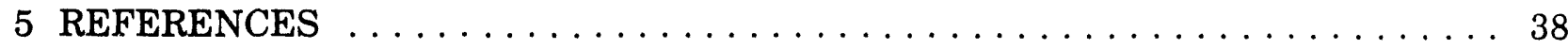

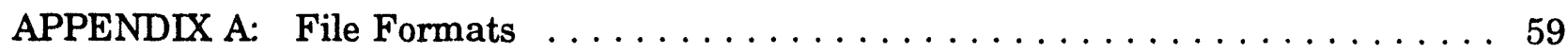

APPENDIX B: Strain Codes, Strain Designations, and Brief Notes

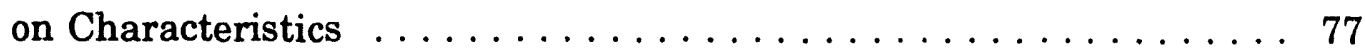

APPENDIX C: Data Codes and Radiation Protocols . . . . . . . . . . . . 83

\section{FIGURE}

1 Diagram of Outcross and Recurrent Backcross Matings Used to Study the Inheritance of Radiation Resistance and Mean Life Expectancy and the Potential Genetic Linkage of These Traits with the Albino Locus 


\section{TABLES}

1 Mean After-Survival Values for the NCI Initial Low-Dose Study . . . . . . . . . . . 42

2 Mean After-Survival Values for the NCI Low-Dose Follow-Up Study . . . . . . . . 43

3 Distribution of Strains and Hybrids across the Single X-Ray Exposures Used in the XAM-3 Experiment . . . . . . . . . . . . . . . . 44

4 Number of Mice in XAM-3 Experiment by Strain, Hybrid, or Genetic Stock; Sexes and Doses Combined ...................... 46

5 Distribution of Experiments GCM-4, 8, and 12 across Strains and Daily Dose Levels .......................... 48

6 Number of Mice Entered into Studies GCM-4 and GCM-8 According

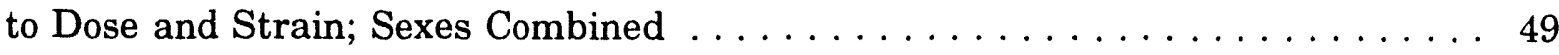

7 Number of Mice Entered into the GCM-12 Study According to Dose,

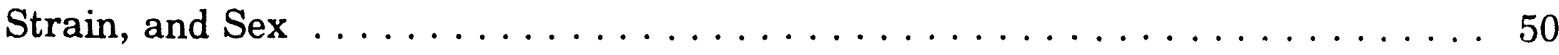

8 Number of $\mathrm{LAF}_{1}$ Mice Entered in the GCM-9B Test of Age Dependence of Response to Daily Irradiation by ${ }^{60} \mathrm{Co} \gamma$ Rays $\ldots \ldots \ldots \ldots$

$9 \quad$ Number of Mice Entered in the GCM-9B Test of Age Dependence of Response to Daily Irradiation by ${ }^{60} \mathrm{Co} \gamma$ Rays . . . . . . . . . . . . 52

10 Number of $\mathrm{LAF}_{1}$ Mice in the GAM-2/GFM-1 Test of Response to Single Exposures of ${ }^{60} \mathrm{Co} \gamma$ Rays at 100 Days of Age (GAM-2), Plus a Split-Dose Series at 450 and 750 R (GFM-1) . ........... 53

11 Number of Mice for the XAM-6 Test of Life Shortening Induced at Doses below the XAM-3 Range of Approximately 0.8-1.2 $\mathrm{LD}_{50}$ Values . . . . . . 54

12 Number of Mice for the XAM-7 Study of Age Dependence of Response to Single Doses of $200-\mathrm{kVp}$ X-Rays below the Acute Lethal Level $\ldots \ldots \ldots \ldots \ldots \ldots \ldots \ldots \ldots \ldots \ldots \ldots \ldots \ldots$

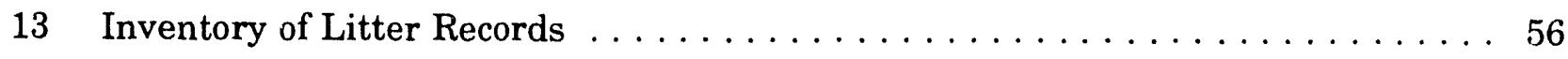

14 Number of Animals Entered into the Pre-Experimental Stock Cage Record According to Strain and Sex 


\section{TABLES (Cont.)}

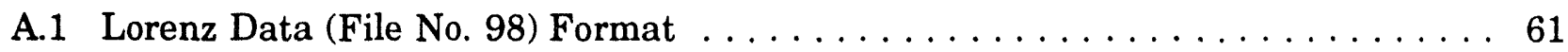

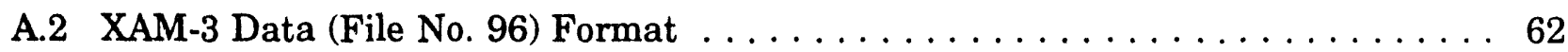

A.3 GCM-4 Data (File No. 87) Format $\ldots \ldots \ldots \ldots \ldots \ldots$

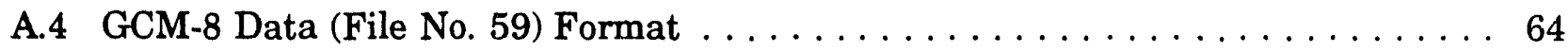

A.5 GCM-12 Data (File Nos. 66 and 27) Format $\ldots \ldots \ldots \ldots 6$

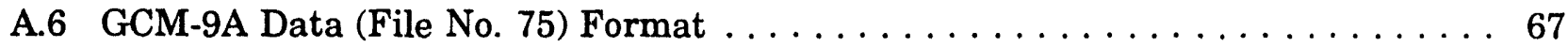

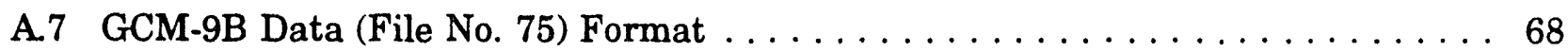

A.8 GAM/GFM Data (File No. 73 [GAM-2] and File No. 82 [GFM-1] combined) Format $\ldots \ldots \ldots \ldots \ldots \ldots \ldots$

A.9 XAM-6 Data (File No. 67) Format $\ldots \ldots \ldots \ldots \ldots \ldots \ldots \ldots \ldots \ldots$

A.10 XAM-7 Data (File No. 69) Format $\ldots \ldots \ldots \ldots \ldots \ldots \ldots \ldots \ldots$

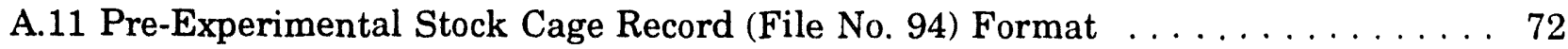

A.12 Mating Record (File No. 88) Format $\ldots \ldots \ldots \ldots \ldots \ldots \ldots$

A.13 Litter Record (File No. 95) Format $\ldots \ldots \ldots \ldots \ldots \ldots \ldots \ldots \ldots$

A.14 Combined Mating and Litter Records 1953-1969 (File Nos. 88 and 95) Format . . 75

C.1 Pre-eIANUS Data Codes $\ldots \ldots \ldots \ldots \ldots \ldots$

C.2 Equivalence of Pre-JANUS and JANUS Codes $\ldots \ldots \ldots \ldots \ldots$

C.3 Pathology Codes $\ldots \ldots \ldots \ldots \ldots \ldots \ldots \ldots \ldots$

C.4 Pre-JANUS Pathology Codes with SNOMED Codes Assigned . . . . . . . . . 89

C.5 Pre-JANUS Radiation Protocol $\ldots \ldots \ldots \ldots \ldots \ldots \ldots$

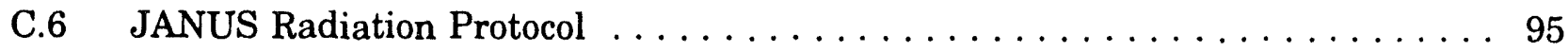




\section{FOREWORD}

In late 1990, the Office of Health and Environmental Research (OHER) of the U.S. Department of Energy (DOE) became interested in creating a central archive of data from long-term studies of the effects of radiation on laboratory animals. This interest prompted us at the Center for Mechanistic Biology and Biotechnology (CMB; formerly the Biological and Medical Research Division) of Argonne National Laboratory to reevaluate the status of our existing data archive. While we focused on the data from the JANUS program and from our studies with the beagle, there was also an extensive archive of magnetic tapes containing the card-image data from studies with mice between 1953 and 1969, before the JANUS program assumed a dominant position. (All early data management used IBM data cards and data manipulation on IBM accounting machines; the availability of a mainframe computer for division use was a distant dream.)

We decided to print out the tape files and evaluate them for completeness, accuracy, readability, and scientific utility. This decision served two purposes. First, it could lead to the creation of an easily accessible database of the pre-JANUS studies, thus extending the record of Argonne's contribution to external radiation toxicology from 1953 to 1993. Second, a serviceable data archive of the early studies with mice could materially contribute to the developing DOE program on interspecies extrapolation, which is to develop models by which response parameters could be transposed from mouse to dog to man. The availability of a long-term participant in the early program, Dr. Douglas Grahn, Senior Biologist (Retired), made possible the archive's creation. Dr. Grahn had supervised the original establishment of the data-record system and the rodification of survivorship data, having previously been trained in such procedures at the Statistics Laboratory, Iowa State College, before joining the Biological and Medical Research Division staff in 1953.

The evaluation, correction, and refiling of the data on laser-read hard disks, as well as the preparation of this document explaining the recreated archive, have been tedious and time-consuming. The data tapes presented, collectively, over 110,000 lines of $60+$ digits, depicting codes for strain, sex, cage, dose, age, survival time, pathology at death, and other characteristics that enabled every line to be unique. The archived data files are now secure and readily accessible for analysis.

The stable funding provided by the U.S. Atomic Energy Commission was essential to the successful completion of the experiments described in this document. Quality longterm animal studies are difficult to conduct and, today, are nearly impossible to initiate. It was, therefore, important to capture the information derived from these studies in a form that will be both intelligible and accessible to future investigators. We thank the U.S. Department of Energy, Office of Health and Environmental Research, for the funding that has permitted the preservation, continued analysis, and documentation of these studies. This support has ensured that these data will remain a valuable resource for future insights into acute and chronic radiation injury, carcinogenesis, and aging.

Eliezer Huberman

Director, Center for Mechanistic Biology and Biotechnology 


\section{ACKNOWLEDGMENTS}

A research program spanning more than 15 years obviously had a number of participants in many areas. These individuals are listed under the category in which they participated most; many individuals participated in two or more areas.

Scientific staff:

G.A. Sacher, D. Grahn, S. Lesher, R.J.M. Fry, J.H. Rust, W.C. Quevedo

Dosimetry:

J. Trier, E. Johnson, W.K. Sinclair, P.F. Gustafson

Statistics (analysis):

J.M. Gurian, R.L. Schweisthal, S. Tyler, W.P. Leslie, R.A. Lea

Statistics

(data management):

C. Fox, M. Dipert, D. Cook, J. Splitt, C. Wisniewski

Laboratory animal care: R.J. Flynn, G. Collins, C. Poole, T.E. Fritz

Laboratory assistants: K.F. Allen, J. Wadman, R. Robertson, A. Sallese, M. Miller, R. Craggs, J. Hulesch, E. Cooke, C. Weber

Also acknowledged are the support and encouragement received from the Director's office of the Center for Mechanistic Biology and Biotechnology, Argonne National Laboratory; from A.M. Brues, E.L. Powers, and M.R. Zelle from the Division of Biological and Medical Research; and from the U.S. Atomic Energy Commission, which provided all of the funding for the studies carried out. 


\section{NOTATION}

\section{Abbreviations}

\begin{tabular}{|c|c|}
\hline AEC & U.S. Atomic Energy Commission \\
\hline ANL & Argonne National Laboratory \\
\hline BIM & Biological and Medical Research Division \\
\hline CMB & Center for Mechanistic Biology and Biotechnology \\
\hline Co & cobalt \\
\hline DOE & U.S. Department of Energy \\
\hline ISU & Iowa State University \\
\hline $\mathrm{LD}_{50}$ & median lethal dose, at which $50 \%$ of test subjects die \\
\hline $\begin{array}{l}\operatorname{LD}_{50 / 30} \\
\ln \end{array}$ & $\begin{array}{l}\text { median lethal dose, at which } 50 \% \text { of test subjects die within } 30 \text { days } \\
\text { natural logarithm }\end{array}$ \\
\hline MAS & mean after-survival \\
\hline MPD & maximum permissible dose \\
\hline NCI & National Cancer Institute \\
\hline OHER & Office of Health and Environmental Research \\
\hline
\end{tabular}

\section{Units}

$\begin{array}{ll}\mathrm{Ci} & \text { curie } \\ \mathrm{cGy} & \text { centigray } \\ \mathrm{cm} & \text { centimeter } \\ \mathrm{d} & \text { day } \\ \mathrm{ft} & \text { feet } \\ \mathrm{Gy} & \text { gray } \\ \mathrm{h} & \text { hour } \\ \mathrm{in} . & \text { inch } \\ \mathrm{kVp} & \text { kilovolt (potential) } \\ \mathrm{L} & \text { liter } \\ \mathrm{mA} & \text { milliampere } \\ \mathrm{min} & \text { minute } \\ \mathrm{mm} & \text { millimeter } \\ \mathrm{qt} & \text { quart } \\ \mathrm{R} & \text { roentgen } \\ \mathrm{rad} & \text { rad } \\ \mathrm{rem} & \text { rem } \\ \text { wk } & \text { week } \\ \mathrm{yr} & \text { year }\end{array}$




\title{
Studies of Acute and Chronic Radiation Injury at the Biological and Medical Research Division, Argonne National Laboratory, 1953-1970: \\ Description of Individual Studies, Data Files, Codes, and Summaries of Significant Findings
}

by

D. Grahn

with the technical assistance of C. Fox, B.J. Wright, and B.A. Carnes

\begin{abstract}
Between 1953 and 1970, studies on the long-term effects of external $\mathrm{x}$-ray and $\gamma$ irradiation on inbred and hybrid mouse stocks were carried out at the Biological and Medical Research Division, Argonne National Laboratory. The results of these studies, plus the mating, litter, and pre-experimental stock records, were routinely coded on IBM cards for statistical analysis and record maintenance. Also retained were the survival data from studies performed in the period 1943-1953 at the National Cancer Institute, National Institutes of Health, Bethesda, Maryland. The card-image data files have been corrected where necessary and refiled on hard disks for long-term storage and ease of accessibility. In this report, the individual studies and data files are described, and pertinent factors regarding caging, husbandry, radiation procedures, choice of animals, and other sgistical details are summarized. Some of the findings are also presented. Descriptions of the different mouse stocks and hybrids are included in an appendix; more than three dozen stocks were involved in these studies. Two other appendices detail the data files in their original card-image format and the numerical codes used to describe the animal's exit from an experiment and, for some studies, any associated pathologic findings. Tabular summaries of sample sizes, dose levels, and other variables are also given to assist investigators in their selection of data for analysis. The archive is open to any investigator with legitimate interests and a willingness to collaborate and acknowledge the source of the data and to recognize appropriate conditions or caveats.
\end{abstract}

\section{HISTORICAL BACKGROUND}

The long-term studies initiated in 1953 had their scientific genesis during World War II. Investigations of the biological effects of radiation exposure were initiated early in the Atomic Energy Program (the Manhattan Project). Strict control measures were going to be needed to prevent excess exposure of laboratory and industrial personnel and of the 
general public to radiation sources expected to be of greater magnitude and complexity than any previously experienced. An important concern was the applicability of the then-existing tolerance dose (or maximum permissible dose, MPD) of $0.1 \mathrm{R} / \mathrm{d}$ of $\mathrm{x}$-rays or $\gamma$ rays. The tolerance dose and the general concept thereof had evolved from clinical radiology experiences, a vastly different environment from that anticipated in the production of large quantities of fissionable materials.

Many studies with animals were initiated in the 1940s under the auspices of the Manhattan Project, Corps of Engineers. These studies were principally done at Columbia University, the University of Rochester, the University of Chicago (Metallurgical Laboratory), the University of California, the Clinton Laboratory (now Oak Ridge National Laboratory), and the National Cancer Institute (NCI). Studies at NCI were under the direction of E. Lorenz and were funded through the Metallurgical Laboratory (now Argonne National Laboratory [ANL]). The Lorenz studies addressed the question of tolerance dose by exposing mice and guinea pigs to doses of radium $\gamma$ rays in the tolerance range of $0.11-8.8 \mathrm{R} / \mathrm{d}$ (8-h day). The survival time data are included in this archive. These studies and those done at the University of Chicago raised questions about the applicability of the tolerance dose or MPD for the two sexes and for both somatic and genetic measures of injury.

At the University of Chicago, theoretical studies of the response to the MPD and of the use of animal data for the evaluation of possible human responses were being developed by G.A. Sacher, A.M. Brues, and others. The need for more extensive exposure facilities became evident from the early studies. In addition, the MPD was lowered from $0.1 \mathrm{R} / \mathrm{d}$ to $0.3 \mathrm{rem} / \mathrm{wk}$ in 1949 and lowered again in 1956 to $5 \mathrm{rem} / \mathrm{yr}$ (approximately $0.1 \mathrm{rem} / \mathrm{wk}$ ). The direct evaluation of the MPD thus became nearly impossible because of logistical and statistical limitations.

In this early period, laboratory animal husbandry was not a well-developed science, so testing at low doses was often confounded by high rates of intercurrent mortality from infectious diseases. One of the confusing outcomes of inadequate animal husbandry was the observation that groups irradiated at low doses sometimes outlived their controls, a phenomenon classified some years later as hormesis. It became imperative, therefore, to generate dose-response data adequate for regression analysis and to employ sample sizes sufficient for actuarial (life-table) analysis.

As a consequence, in the late 1940s, the construction plans for Building 202, for the Biological and Medical Research Division (BIM) at ANL, incorporated two large walk-in, live-in radiation rooms designed for ${ }^{60} \mathrm{Co} \gamma$ irradiation of large numbers of small mammals. The low-level $\gamma$-ray room, designed for the remote operation of an approximately $10-\mathrm{Ci}$ source, became the principal experimental facility. The high-level $\gamma$-ray room, designed for kilocurie sources, was used for short-term (acute) and fractionated exposures. These two rooms became available for experimental exposures in mid-1954.

The importance of life-table statistics for the analysis of long-term injury was established in the early theoretical approaches developed by G.A. Sacher. The principles and expectations are presented in simple terms by Brues and Sacher (1952). In essence, they 
note that the Gompertz function (life table) of an exposed group would be displaced from the normal or control life table in a predictable manner in response to acute or chronic injury and that the induced injury (displacement) would be substantially additive to the normal processes of aging.

Building 202 was occupied in November 1952. From January 1, 1953 (the arrival of D. Grahn), to November 1954, G.A. Sacher, D. Grahn, other members of the BIM staff, and personnel from the Remote Control Engineering Division of ANL pursued the logistical issues and preliminary experiments needed to start a major series of animal studies. These issues included choice of animals, design of cages and cage racks, dosimetry, animal husbandry, installation and debugging of source control mechanisms, data management and codification, selection of daily dose levels, and preparation of program plans and their presentation to U.S. Atomic Energy Comwission (AEC) headquarters. The ${ }^{60} \mathrm{Co}$ sources were assembled in February 1953, and trial runs in the low-level $\gamma$-ray room were initiated in July 1954 . The first major long-term study (GCM-4) was initiated on November 18, 1954.

A decision was made in mid-1953 to have all experimental data codified and stored on standard IBM punch cards. Appendix A presents the format and contents for each file. A codified record was made for all major experiments and for most mating records.

In the following documentation, the individual experiments will be explained and the specific logistical details such as animal supply, caging, exposure parameters, animal care, animal entry and exit, pathologic findings, and data management will be presented. The experiments will be discussed in the general chronological order of their initiation. The duration of individual experiments varied. Some were performed simultaneously and used a common control (GCM-4, GCM-9, GAM-2, and GFM-1). Others were carried out in overlapping periods. Before the JANUS reactor experiments began in 1971 (Grahn et al. 1972b), a continuous series of acute and chronic injury experiments was being performed. Not all are in these files, as some were probing studies of limited scope or limited tests of a genetic variable.

\subsection{DESCRIPTION OF APPENDICES}

Three appendices provide details on the data files, radiation exposure levels, mouse strains, and numerical codes used to identify the fate of each animal. The contents of the appendices are described below.

\subsubsection{Appendix A: File Formats}

Appendix A (Tables A.1 to A.14) contains the format for the original IBM card-image file for each experiment or data file. In those instances where several files have been merged, the format has been modified to describe the actual file available. The original file numbers have been maintained so records can be related to other data archives. 
All information is in numerical form and is constrained to the 80-column IBM card. The same columns were used for the same type of data in most files to facilitate comparisons among separate experiments and to reduce errors in data entry and readout. Between 60 and 75 columns were usually required. The first six columns were for housekeeping or program identification. In some files, several columns are deliberately left blank to preserve the consistency of column use.

\subsubsection{Appendix B: Strain Codes, Strain Designations, and Brief Notes on Characteristics}

The numerical code for each strain, hybrid, or genetic or mutant marker stock is given in Appendix B. A brief description or genetic identification is also presented. The mouse colony was established originally with well-known and commercially available inbred strains. Background documentation on such strains is widely available (Staats 1968, 1980; Green, E.L. 1966). Standard nomenclature was used for all strains or stocks or is given for identification. The inbred strains obtained from the Department of Genetics, Iowa State University (ISU) at Ames, Iowa, in 1963 were less well known, so some background is presented for these in the appendix. The mutant stocks all carry one or more known mutations that are described in the document by M.C. Green (1966).

For the record here, note that full-sib matings were used to maintain all inbred strains, and all matings were registered in a single sequence of mating numbers. Each litter within a mating was separately recorded in a pedigree book for the given strain. The mating

number and litter sequence (parity) number are unique identifiers within and across the strain and are used in many of the data files.

The mice weaned in each litter were numbered in a unique sequence for each strain and listed in a pedigree book. The individual animal was marked by toe clipping to accommodate numbers from 00 to 99 . The repetition of numbers with each advancing hundred in the pedigree presented no unavoidable problems. In segregating generations, the coat color or other characteristics were also recorded for each mouse.

\subsubsection{Appendix C: Data Codes and Radiation Protocols}

Appendix C consists of six tables.

Table C.1. Pre-JANUS Data Codes. The original numerical codes used to identify sex, mode of exit from an experiment (death, discard, etc.), whether an autopsy was performed, and, for selected experiments, the individual's coat color are given in this section.

Table C.2. Equivalence of Pre-JANUS and JANUS Codes. The equivalence of autopsy and exit codes for the two series of experiments is presented, as is a conversion of pre-JANUS experiment codes to a JANUS-format code. 
Table C.3. Pathology Codes. The original numerical pre-JANUS codes are presented and are matched to the JANUS-equivalent three-letter and fourletter gross pathologic diagnosis codes. The equivalent JANUS Combined Pathology File codes and definitions are also stated. Because of the limited diagnostic information given in the pre-JANUS histopathologic records, code equivalence has been constrained to the JANUS gross pathologic diagnoses.

Table C.4. Pre-JANUS Pathology Codes with SNOMED Codes Assigned. In this section, the appropriate Systematized Nomenclature of Medicine (SNOMED) codes are assigned to the pre-JANUS codes.

Table C.5. Pre-JANUS Radiation Protocols. The radiation protocols are converted to the JANUS format in this section. The original $\gamma$-ray or $\mathrm{x}$-ray exposure levels that were given as "roentgens in air" (F) are converted to midline tissue doses in rads or centigray (cGy) to be in equivalent terms to the doses given in the JANUS series. Both the original doses in roentgens and the converted doses in centigrays are given. The conversion factor for $200-\mathrm{kVp}$ x-rays is $0.8714 \mathrm{cGy}=1 \mathrm{R}$; and for ${ }^{60} \mathrm{Co} \gamma$ rays, it is $0.8966 \mathrm{cGy}=1 \mathrm{R}$.

Table C.6. JANUS Radiation Protocols. For the record here, the radiation protocols for all the JANUS experiments are presented. 


\section{NATIONAL CANCER INSTITUTE STUDIES, 1943-1953}

The NCI studies, performed under the general supervision of E. Lorenz and V.E. Heston, were reported in detail by Lorenz et al. (1954). Several less compreherısive reports were also published (Lorenz 1950; Lorenz et al. 1947, 1951, 1955). The Lorenz data file held at ANL is not all-inclusive for these early studies, but what is available has some noteworthy scientific interest and is therefore included in the data archive (Appendix A, Table A.1).

The file contains the survival data from the initial low-dose study started between February and April 1943, with the $\mathrm{LAF}_{1}$ mouse. That study employed exposures of $0,0.11$, $1.1,2.2,4.4$, and $8.8 \mathrm{R} / \mathrm{d}$ (8-h day) of $\gamma$ rays from encapsulated radium sulfate sources. The file also includes the data from a low-dose follow-up study that employed the two exposure levels of $0 \mathrm{~K}$ and $0.11 \mathrm{R} / \mathrm{d}$; this study was carried out from 1949 to 1953 . Other data in the file involve the female C3Hf mouse that was used to study the induction of mammary tumors. Portions of these data were reported (Lorenz et al. 1951), but some of the data in this file have apparently never been analyzed or discussed. Summaries of the survival data are presented here with some comment and caveats. No pathology data are available, but the pertinent published reports do present tumor occurrences by age interval so that pathologyspecific life tables could be generated.

\subsection{LOW-DOSE STUDIES}

The initial low-dose study employed $302 \mathrm{LAF}_{1}$ mice, in equal numbers for the two sexes. The six daily exposure levels were $0,0.11,1.1,2.2,4.4$, and $8.8 \mathrm{R} / \mathrm{d}$ (8-h day). Two radium sources were used, one for $0.11 \mathrm{R} / \mathrm{d}$ and the other for the four levels from 1.1 to 8.8 R/d. The mice were exposed at night. Three separate rooms were therefore involved: a room for controls, a room for the 0.11-R/d group, and a room for all other exposure levels. Thus, the microenvironment was confounded at the outset. Mean age at entry was $60 \mathrm{~d}$ for controls, $52 \mathrm{~d}$ at $0.11 \mathrm{R} / \mathrm{d}$, and progressed from $62,70,74$, and $85 \mathrm{~d}$ for the levels of $1.1,2.2$, 4.4 , and $8.8 \mathrm{R} / \mathrm{d}$, respectively; age at entry was, therefore, also confounded. The original reports did not give survival time separately for the sexes, and there were some errors in the values given. The present file gives a set of mean after-survival (MAS) values, as shown in Table 1 (tables begin on p. 42). The oversurvival at $0.11 \mathrm{R} / \mathrm{d}$ was troublesome but not statistically significant for either sex or for the combined sexes. The regression of $\ln (\mathrm{MAS})$ on $\mathrm{R} / \mathrm{d}$ was -0.0450 for all data and -0.0426 with the 0.11 group deleted. The correlation coefficient was -0.996 , and the estimated intercept of $709 \mathrm{~d}$ (compared with the observed value of $714 \mathrm{~d}$ ) suggested the data at $0.11 \mathrm{R} / \mathrm{d}$ might have been a minor aberration.

The comparison of $0 \mathrm{R}$ with $0.11 \mathrm{R} / \mathrm{d}$ was redone in the low-dose follow-up study, with larger samples, in 1949 to 1953 . These values are summarized in Table 2 (the survival data are in the file). The oversurvival at $0.11 \mathrm{R} / \mathrm{d}$ for the combined sexes was $58.1 \pm 16.2 \mathrm{~d}$ $(p<0.01)$, and that for the males alone was $100.2 \pm 20.1 \mathrm{~d}$, also highly significant. The excess for females was not significant. 
The data from these two studies have become almost legendary for those who wish to believe that extremely low doses of radiation may be harmless, let alone possibly beneficial. Some cautionary notes are in order. Table 1 in the article by Lorenz et al. (1955) gives mean survival times that are actually ages at death. This is an error in the published report and served to exaggerate the differences seen in the original study. A more serious concern, in addition to the use of different holding rooms for the two dose groups, is the note by Lorenz et al. (1955) that the original controls developed dermatitis and had to be replaced aboui a year after the experiment began. This type of experimental heterogeneity cannot be rationalized retrospectively in the absence of information on pathologic findings at death. This file does not contain any pathology data. The published report does note that reticular tissue tumors increased in frequency at $0.11 \mathrm{R} / \mathrm{d}$ for both sexes, lung tumors increased in males, and more mammary and ovarian tumors were observed. Otherwise, there was little or no difference between the two dose groups.

\subsection{FEMALE C3Hf MOUSE STUDIES}

The balance of the file contains survival data on normal and "castrate" C3Hf female mice. One group of 96 mice exposed to $8.8 \mathrm{R} / \mathrm{d}$ was studied and reported in detail (Lorenz et al. 1951), with emphasis on mammary tumor induction. Controls referenced in that report are not in this file, except for 16 control mice that were held until the last irradiated mouse died; then the controls were sacrificed. A group of 100 mice exposed to $4.4 \mathrm{R} / \mathrm{d}$ were apparently not reported. Control and 8.8-R/d groups of castrate females (96 and 144 animals, respectively) also seem to have been forgotten. Life shortening in these data was on the high side $(-0.057 / \mathrm{R} \cdot \mathrm{d})$, but the data are internally consistent. These studies with the C3Hf mouse were initiated in 1946, 1948, and 1950-1951. No pathology data are available in the file, but rec ailed time-interval data on mammary, lymphoid, and ovarian tumors are in the Lorenz et al. (1951) article for 91 autopsied mice exposed to $8.8 \mathrm{R} / \mathrm{d}$. 


\section{ARGONNE EXPERIMENTS}

\subsection{EXPERIMENT XAM-3}

\subsubsection{Background}

D. Grahn joined the BIM staff at Argonne on January 1, 1953, to work with G.A. Sacher in developing the long-term $\gamma$-irradiation studies and to introduce the genetic variable into the experimental plans. The results of experiments conducted during the 1940s indicated that considerable genetic variation existed in the acute and chronic responses to radiation exposure, but this variation in response lacked quantitation and an adequate genetic analysis. The selection of inbred strains with which to carry out the genetic studies also served to broaden the basis for selection of strains or hybrids for the major long-term studies. The background of the principal investigator (D.G.; animal genetics, statistics, veterinary pathology) also meshed well with the planned program.

Breeding colonies of six diverse, well-cha acterized, and widely available inbred strains were established in 1953-1954. These strains were the $\mathrm{A} / \mathrm{Jax}, \mathrm{BALB} / \mathrm{c}$, and C57BL/6 from the Jackson Laboratory, Bar Harbor, Maine, and the A/He, C3Hf/He, and C57L from W.E. Heston, NCI. Characterization of the strains for three primary variables reproductive performance, radiation resistance, and life expectancy - was begun in September to October 1953, and the activity became identified as the XAM-3 experiment.

Exposure levels were established iteratively to determine the acute lethal dose $\left(\mathrm{LD}_{50 / 30}\right)$ values for the $200-\mathrm{kVp}$ x-rays chosen as the radiation source for this experiment. The XAM-3 experiment continued with only brief interruptions for nearly 20 years. The last control died in mid-1972. Overall, the experiment provided a codifiable and consistent manner for studying the three primary variables noted above plus the major pathologic findings at death for 15 inbred strains, 4 genetic marker stocks, and 14 outcross/backcross generations from the $\mathrm{BALB} / \mathrm{c}$ and $\mathrm{C} 57 \mathrm{BL} / 6$ inbred lines. The experiment was a means of continuously evaluating genetic aspects of radiosensitivity and life expectancy. Although XAM-3 lacked the formal design parameters of a set piece, it served as a concurrent baseline study and source of information for the design of subsequent experiments (Appendix A, Table A.2).

\subsubsection{Experimental Design}

\subsubsection{Radiation Variables}

All exposures were done with a GE Maximar x-ray therapy unit. Operational settings were $200 \mathrm{kVp}, 15 \mathrm{~mA}$; a half-value layer of $1.1 \mathrm{~mm}$ of copper; a dose rate of 21-23 R/min in air at a target distance of $27 \mathrm{in}$. $(68.6 \mathrm{~cm})$. Approximately 18 mice could be irradiated at once on a rotating Bakelite disk that was $0.5 \mathrm{in} .(1.3 \mathrm{~cm})$ thick and about 
24 in. $(61 \mathrm{~cm})$ in diameter. The mice were restrained in 1-in.-diameter, perforated, celluloid centrifuge tubes, which were capped with a standard cork and held down on the turntable with an elastic tie. Exposure times were 20-40 min. The tabletop was about $2 \mathrm{ft}(61 \mathrm{~cm})$ above the floor, and the dosimetric readings included backscatter from walls, floor, and the tabletop. All measurements were done with a $1-\mathrm{cm}^{3}$ Victoreen thimble-chamber dosimeter. Table 3 presents the exposure levels used for each strain or hybrid.

\subsubsection{Animals}

Although the XAM-3 study continued for nearly 20 years, it subdivided into three major parts to study genetic variation in radiation resistance. The first part involved the six principal inbred strains (A/He, A/Jax, BALB/c, C3Hf/He, C57BL/6, and C57L), and the $\mathrm{F}_{1}$, $F_{2}$, and $F_{3}$ hybrids of strains $\mathrm{C} 57 \mathrm{BL} / 6$ and $\mathrm{BALB} / \mathrm{c}$. The second part focused on the outcross/backcross generations from the two parent strains noted above (Figure 1). The third part involved the inbred and genetic marker stocks that were brought to ANL from the ISU Departroent of Genetics in September 1963. In terms of the ANL strain codes (Appendix B), the three studies involved codes $02-14,15-44$, and 47-62, respectively.

Generally, the mice were between 60 and $120 \mathrm{~d}$ of age at exposure. As the animals were all bred at ANL, it was not possible to predict the availability of adequate samples for a given replication; therefore, age could not be rigorously controlled. Table 4 presents, for each strain, the total number of animals involved and the number held for the study of chronic injury and survival time for both irradiated and control groups. In Table 4, these latter numbers are for mice dying of natural causes at 61 or more days after exposure. The difference between these numbers and the total numbers would be accounted for by acute (1-30 d) and subacute (31-60 d) deaths plus accidental losses and discards. Not all strains and/or dose groups were part of the long-term studies.

For ease of presentation, the tabulated data in Table 4 were summed across the two sexes and all exposure levels within each strain, although the file contains the data separately by strain, sex, dose, and survival time. The two sexes are about equally represented, but the sample size for irradiated survivors is largest at low doses and declines with increasing dose. Because the range of doses was generally from about 0.8 to 1.2 times the $\mathrm{LD}_{50}$, the data can be pooled for comparison of controls versus exposed by using a weighted inean exposure level.

\subsubsection{Animal Husbandry}

The mice were housed in plastic "shoe-box" cages designed to hold 12-15 mice. Stainless-isteel cage tops contained a bin for pelleted food and a water bottle. Bedding was usually sterilized wood shavings, although the exact bedding material changed from time to time over the years. Food and water were always available. Cages were changed at least once a week. They were kept on racks or shelves along the walls of rooms in the BIM animal facilities. 


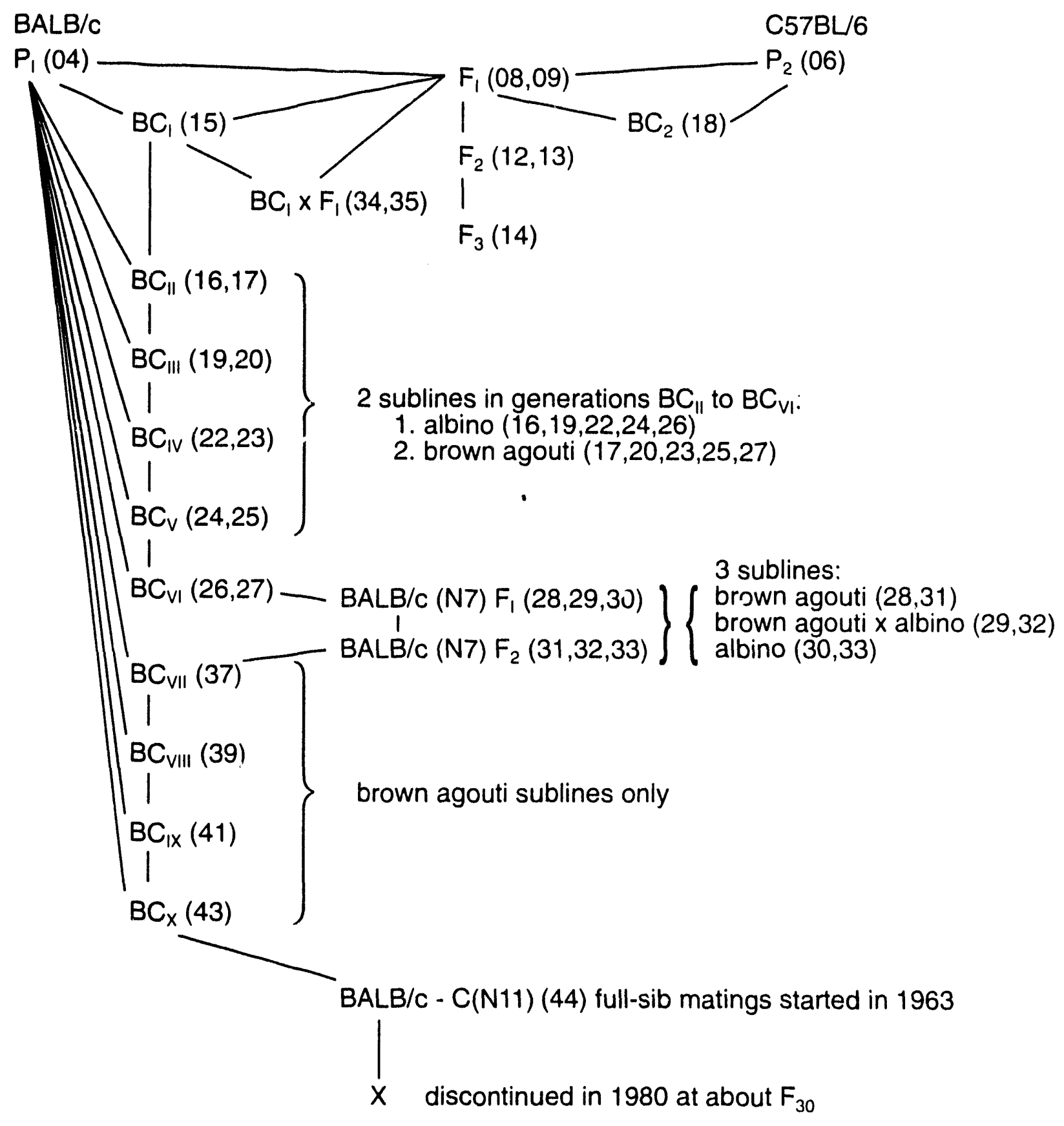

FIGURE 1 Diagram of Outcross and Recurrent Backcross Matings Used to Study the Inheritance of Radiation Resistance and Mean Life Expectancy and the Potential Genetic Linkage of These Traits with the Albino Locus (strain codes in parentheses) 
In early stages of the study (1953-1960), bacteremias would periodically occur and cause the death of all mice in a cage within a matter of days, without any relationship to dose or known dose-time mortality expectations. Such cages were discarded from the study. A precautionary statistical measure involved the exposure of mice from a single cage to two to four different dose levels, thus distributing the impact of infection more randomly across doses. If mice were to be held for lifetime observation, they normally remained in the original cage, though some recaging occurred because of the demand for space.

\subsubsection{Data Recorded}

The animals were checked twice daily on weekdays and once daily on weekfnds. Date and post-exposure day of death were recorded. For long-term survivors, a modest amount of information on the pathologic findings at death was recorded on a standard autopsy record sheet. Tissues were taken from some animals, but only a limited histopathologic examination was actually done. Unfortunately, the original autopsy record sheets were inadvertently discarded; however, some useful data are in the original data books from which the data cards were keypunched.

The acute period of response was limited to the usual 30-d interval following exposure. If the survivors were to be discarded, that would generally be done before $50 \mathrm{~d}$. Early analyses of :... Lata for all strains showed that acute mortality actually ceased before the 30th day. A few subacute deaths occurred sporadically over the next $30 \mathrm{~d}$, and by 60-90 d after inadiation, the first evidence of chronic injury would appear, usually as a localized thymic lymphoma large enough to cause terminal respiratory distress. The rather limited pathology codes used indicate the limitations of the data (Appendix C, Table C.3). Nevertheless, the major observations were adequate to differentiate the strains and hybrids by their innate or genetic propensities to succumb to different causes of death.

Because the animals were all bred at Argonne, the mating and/or litter record of each mouse was available and became part of the permanent record. The original intentions were to seek any correlations that might exist among such basic variables as maternal age, parity, litter size, age at entry, weight at entry, and, if possible, early mortality in the given litter or in other parities of the given dam. Analytical capabilities at the time were not adequate to carry out these plans except for an analysis of the influence of age at entry, parity, and litter size on $\mathrm{LD}_{50 / 30}$ values for four inbred strains (Grahn and Hamilton 1957).

\subsubsection{General Findings}

The XAM-3 study consisted of three semi-independent efforts that partially overlapped in their execution. The results of these efforts were never completely reported, although extensive statistical analyses were carried out. The unpublished findings are on file, and a brief summary is given here. Many analyses should probably be redone in light of the present computational capabilities of handling more complex survival analyses. 


\section{Part I: The Primary Inbreds and the $F_{1}, F_{2}$, and $F_{3}$ Hybrids of Strains BALB/c and C57BL/6}

The results of the first part of XAM-3 were published by Grahn and Hamilton (1957) and Grahn (1958a, 1958b, 1960). Significant differences in acute $L_{50 / 30}$ values for $200-k V p$ $x$-rays were observed, with a maximum difference among inbreds of $500 \mathrm{R}(\mathrm{BALB} / \mathrm{c})$ versus $630 \mathrm{R}(\mathrm{C57BL} / 6)$. The $\mathrm{F}_{1}$ generation showed significant hybrid vigor with an $\mathrm{LD}_{50}$ of $660 \mathrm{R}$, and there was no difference between the two reciprocal crosses (B6C vs. CB6 $\mathrm{F}_{1}$ generations). The $\mathrm{LD}_{50}$ values for the $\mathrm{F}_{2}(628 \mathrm{R})$ and $\mathrm{F}_{3}(613 \mathrm{R})$ generations regressed to that of the C57BL/6, the resistant parent. The dose-response slope dropped sharply in these two genetically segregating generations, reflecting significant increases in genetic variance. Heritability of radiation sensitivity was estimated to be about 0.55 . The $F_{2}$ mice also showed a significant relationship between radiosensitivity and the segregation of the albino gene. $L_{50 / 30}$ values were $602 \pm 9 \mathrm{R}$ for albinos and $639 \pm 8 \mathrm{R}$ for all non-albinos.

With regard to long-term effects, $\mathrm{LD}_{50}$ values were positively corrolated with the normal control life expectancies - that is, the higher the acute $L D_{50}$, the greater the life expectancy. There was some variation among strains in the life-shortening effect per roentgen, but much of this variance could be reduced by removing the specific effect of lymphoreticular tumor deaths and ovarian tumor incidence. Life shortening was estimated to be $28 \mathrm{~d} / 100 \mathrm{R}$ for all strains and both sexes as a basic parameter to which the effects of tumor incidence would be added. At the $\mathrm{LD}_{50}$, life expectancy was reduced by $19 \%$ for all strains after appropriate adjustments for strain differences in their pathologic affinities (Grahn 1960).

\section{Part II: The BALB/c:C57BL/6 Outcross and Backeross Generations}

This portion of the XAM-3 study involved a rather classic recurrent backcross series, as diagrammed in Figure 1. A primary goal was to define the genetic behavior or transmissibility of radiation response and its corollary of life expectancy. It also endeavored to prove and quantitate the linkage between the qualitative coat-color trait at the albino locus and the quantitative trait of radiosensitivity. Recurrent backcrosses to the sensitive parent $\left(\mathrm{P}_{1} ; \mathrm{BALB} / \mathrm{c}\right)$ were carried sut to the sixth backcross, where less than $1 \%$ residual genotype from the resistant parent $\left(\mathrm{P}_{2} ; \mathrm{C} 57 \mathrm{BL} / 6\right)$ would be expected. Starting with the second backcross $\left(\mathrm{BC}_{\mathrm{I}} \times \mathrm{P}_{1}\right.$ ), two family lines were established (an albino family and a brown agouti family) to better isolate the genetic factors controlling sensitivity. $\mathrm{LD}_{50}$ values were derived for all generations, and control survival values were attained for the $\mathrm{BC}_{\mathrm{I}}, \mathrm{BC}_{\mathrm{II}}, \mathrm{BC}_{\mathrm{III}}$, and $\mathrm{BC}_{\mathrm{VI}}$ generations.

The first backcross to the resistant parent $\left(\mathrm{F}_{1} \times \mathrm{C} 57 \mathrm{BL} / 6\right)$ was also done, along with the cross of the $\mathrm{BC}_{\mathrm{I}}$ back to the $\mathrm{F}_{1}$. The latter cross was done to test a prediction model, and both $\mathrm{LD}_{50}$ and long-term survival values were collected.

Analyses of the above data were performed, and several summaries were presented (Grahn et al. 1962,1964). The linkage analysis was mathematically and genetically complex 
and required assumptions that were only testable by the analysis of residual variances. The endpoints $\left(\mathrm{LD}_{50}\right.$ values by coat-color family and survival data) are, characteristically, statistically noisy, making for large uncertainties. In addition, the baseline $\mathrm{LD}_{50}$ values for the parent strains changed during the course of the st ly because of improved animal care procedures. The $\mathrm{LD}_{50}$ value increased by $10 \%$ for the sensitive parent, from 500 to $545 \mathrm{R}$, and increased from 660 to $700 \mathrm{R}$ for the $\mathrm{BCF}_{1}$. Nevertheless, an estimate of the linkage relationship was desived along with an estimate of the portion of the difference between the $P_{1}$ and the $F_{1}$ that was linked to the albino locus. These estimates were 0.21 for the recombination frequency that involved $31 \%$ of the $F_{1}-P_{1}$ difference (Grahn et al. 1962).

$\mathrm{LD}_{50}$ values and control life expectancies were also positively correlated, as was previously seen among the inbred strains. Life expectancies and $\mathrm{LD}_{50}$ values for the sequence of backcrosses steadily and conjointly declined as the proportion of BALB/c genotype increased (Grahn 1972). Mean life expectancy from birth dropped from $850 \mathrm{~d}\left(\mathrm{~F}_{1}\right)$ to $570 \mathrm{~d}$ $\left(\mathrm{BC}_{\mathrm{III}}\right)$, while $\mathrm{LD}_{50}$ values dropped from 700 to $560 \mathrm{R}$.

Although this portion of the XAM-3 study was never fully reported, a detailed summary is available in Grahn et al. (1964). The backcross series was extended to the tenth generation with the brown agouti family, whence full-sib inbreeding was begun to establish a congenic $B A L B / c$ line that was a brown agouti non-albino. The standard $B A L B / c$ line is also brown agouti, but it is covered by the albino trait. By 1968, four or five years after the line was established, $L D_{50}$ values were $567 \mathrm{R}$ for the original $B A L B / c$ and $581 \mathrm{R}$ for the $\mathrm{BALB} / \mathrm{c}-(\mathrm{N} 11)$ (Appendix B, strain code 44 ).

\section{Part III: The ISU Strains and Mutant Stocks}

In September 1963, nine inbred strains and four mutant marker stocks were brought to Argonne from the Department of Genetics, ISU. These had been maintained at ISU by J.W. Gowen (D. Grahn's major professor) for many years; some had been at the Department of Genetics since the early 1930s and others had come from the Rockefeller Institute in 1938 when Gowen took the position at Iowa State. The principal background of the strains was their known resistance or susceptibility to the infectious disease known as mouse typhoid, caused by Salmonella typhimurium. When Gowen moved to Colorado State University, he took the stocks and some ongoing experiments that were funded by the AEC. Moving the stocks to ANL in 1963 was a "safekeeping" maneuver agreed to by all parties, including the AEC. D. Grahn agreed to characterize the stocks in a manner similar to that used for the regular inbreds and hybrids (see Parts I and II above) and, thus, extend the range of known genetic variation available for radiation studies.

Four strains (C, K, Q, and N) originated at the Rockefeller Institute for Medical Research (Webster 1937); strain S at ISU (Schott 1932); strain Z at the Rockefeller Institute Yellow Fever Laboratory in the early 1930s; strain E from a dealer in Pennsylvania; and the $\mathrm{Bab}$ and $\mathrm{BaB}$ lines were originally $\mathrm{BALB} / \mathrm{c}$ mice given to J.W. Gowen in 1932 . The marker stocks were obtained from various sources during the 1950 s and include several mutants 
originally detected at ISU. Appendix B contains more details on these strains and stocks (codes 47 through 58 and code 61).

Data were collected on the $\mathrm{LD}_{50}$ for $\mathrm{x}$-rays, long-term survival of mice exposed to single midlethal doses, control life expectancy, major pathologic findings at death, reproductive performance, and, for selected stocks, survival under daily $\gamma$ irradiation. The data have never been fully assembled, analyzed, or interpreted because of Dr. Gowen's death in September 1967 and because of major changes in program priorities, which included the programmatic justifications and reviews for critical modifications of the JANUS : eactor and the proposed JANUS research program. $\mathrm{LD}_{50}$ estimates are available, as are con trol survival values and some reproductive performance data. Pathology data are in data books but not in the computer files. The following are some of the observations.

1. $\mathrm{LD}_{50}$ values ranged from about 475 to $750 \mathrm{R}$. The lowest value was for mice carrying the $W^{a}$ (Ames dominant white spotting) gene, which causes a deficiency in hematopoietic response to radiation injury. The Rockefeller strains $\left(C, K, Q\right.$, and $N$ ) did not have $L_{50}$ values that correlated positively with their known differences in response to bacterial infection, as was seen among the other ISU inbreds. Control mean life expectancy also had very little relationship to the $\mathrm{LD}_{50}$ value, in contrast to the high positive correlation seen among the regular inbreds (see Part I, p. 12).

2. Control mean life expectancies from approximately $100 \mathrm{~d}$ of age ranged from $200 \mathrm{~d}$ to over $700 \mathrm{~d}$, with females generally outliving males. The lowest expectancies ( $<350 \mathrm{~d}$ ) were mostly in the mutant tester stocks (strains 56, 57, and 58), but several inbred lines also had poor survival times. Pneumonia was a common cause of death in these cases. Among the 13 stocks, however, the spectrum of major pathologic findings was quite varied, and some hand tallies are on file. The usual array of neoplastic diseases was seen (lymphoreticular, lung, liver, ovarian, mammary, and connective tissue), as were some heart thrombi and cases of the liver herniating through the diaphragm. The pathology records are not complete because the detailed autopsy records were among those inadvertently discarded. Major differences among stocks could be validated by tabulation of existing handwritten records in data books and files and by entering the data as they exist into the computer files.

3. Reproductive performance among the stocks was generally within the customary range for inbred mice. Between $5 \%$ and $25 \%$ of the matings were sterile, average litter sizes at birth were between 5 and 9 , and preweaning losses were between $15 \%$ and $35 \%$ (though several stocks were as high as $50-60 \%$ ). Most stocks had females in single-pair matings that were in production for 5-6 months and 
produced four to six litters. One uniquely resistant strain, $\mathrm{S}$, produced an average of only two large litters per dam that then suffered $50 \%$ preweaning losses. The whole mix of characteristics have not been fully analyzed for these strains and stocks from ISU.

\subsection{EXPERIMENTS GCM-4, GCM-8, AND GCM-12}

\subsubsection{Background}

These three studies are documented conjointly because GCM-4 (Appendix A, Table A.3) established the basic experimental parameters. GCM-4 and GCM-8 (Appendix A, Table A.4) were done simultaneously, and GCM-12 (Appendix A, Table A.5) was an extension of GCM-4 and GCM-8 to lower doses. The best discussion of the history and background is in the introductory sections of Sacher and Grahn (1964).

Briefly, the duration-of-life irradiation procedure evolved frọm the studies by Lorenz (1950) and Lorenz et al. (1947, 1954) carried out at the NCI from 1943 to 1945, and by Sacher (1956b) at the University of Chicago Metallurgical Laboratory from 1944 to 1946. Daily irradiation was initiated at an age generally considered equivalent to the young adult human (i.e., 50-90 d of age in the NCI studips and 40-60 d in the Sacher study). The procedure tested the concept of tolerance dose (or MPD), provided data on responses to protracted exposure as compared with short-term (or acute) exposures, and gave data on all of the typical radiation syndromes but without the abruptness and incompleteness associated with responses to single doses. The resulting continuum of responses provided a complete picture of radiation injury that lent itself to good statistical analysis and to the development of more sophisticated hypotheses on the mechanisms of chronic radiation injury (Brues and Sacher 1952).

At the outset of these studies, there was no consensus on the biological basis of longterm injury, how to model it, or how best to study it experimentally. The ANL approach had its detractors; however, our daily irradiation paradigm brought out, in proper sequence, all known and some previously unknown radiation syndromes. This was the strength of our approach, which was based on an analytical and theoretical model (Brues and Sacher 1952) that we believed to be superior to competing models that we considered simplistic and incomplete.

The duration-of-life irradiation procedure did generate two problems, neither of which has been fully explained or rationalized, though a reanalysis of the full database now available might provide some answers. These problems are hormesis and wasted radiation. Hormesis (survival of low-dose groups beyond their controls) is probably primarily induced early in the exposure history, and wasted radiation is a terminal issue (does the individual respond to exposures occurring in the last part of its lifetime?). 


\subsubsection{Experimental Design}

\subsubsection{Radiation Variables}

The same basic exposure procedures were employed in all three studies, and these are presented in detail in Sacher and Grahn (1964). A 12-in. (30.5-cm), linear, 6- to $8-\mathrm{Ci}^{60} \mathrm{Co}$ source was located in the center of the low-level $\gamma$-ray room. The room's dimensions were $24 \times 24 \times 12 \mathrm{ft}$ high $(7.3 \times 7.3 \times 3.65 \mathrm{~m}$ high $)$. It was a ground-level concrete bunker with walls $2 \mathrm{ft} 8 \mathrm{in}$. $(81 \mathrm{~cm})$ thick with an L-shaped entrance maze. The source was operated remotely by an electromechanical timer. The animals were irradiated during the night hours (the usual period of activity for most small mammals). Exposure periods varied between about 8 and $12 \mathrm{~h}$, depending on source strength. The period was increased by 5 -min increments at intervals calculated to compensate for source decay.

Dosimetry was initially done with a Victoreen thimble-chamber dosimeter inserted into an animal cage at the normal location of the animals. Ultimately, a measure of "cageaverage" absorbed dose was derived with a phantom designed by W.K. Sinclair (Sacher and Grahn 1964; Sinclair 1963). Backscatter was high close to the walls and floor, so these areas were not used. All structural materials in the room were plastic or aluminum, except for the stainless-steel cage tops and glass water bottles. The absorbed dose for mice under normal conditions and room loadings was 0.9 rad per roentgen in air (researchers should note that all original records are in terms of roentgens in air).

Experiments GCM-4 and GCM-8 were carried out simultaneously, and the above dosimetric remarks pertain to both. To obtain two or three dose rates lower than those available for GCM-4 (daily doses less than $5 \mathrm{R} / \mathrm{d}$ ), several modifications were made in 1958. A 1-in. (2.5-cm), $120^{\circ}$ lead shield was mounted on a steel tripod next to the source-up position, and a 4-in. (10-cm) bulk lead shield was mounted in the southeast corner of the room. The source shield produced large areas where daily doses were below $3 \mathrm{R} / \mathrm{d}$, and the bulk shield produced a limited area with a daily dose of $0.3 \mathrm{R}$. The dose levels of $0.3,1.3$, and 2.6 R/d were thus available for the GCM-12 study.

Absorbed dose measures were not made in the shielded areas, but pulse-height dosimetry was done by P.F. Gustafson. While the characteristic ${ }^{60} \mathrm{Co} \gamma$-ray energy of about 1.2 $\mathrm{MeV}$ prevailed, there was a considerable increase in the size of the degraded energy spectrum. The absorbed dose of $0.9 \mathrm{rad} / \mathrm{R}$ in air given in Sacher and Grahn (1964) could therefore be a high estimate. The fully loaded room (racks, cages, mice, food, water) also degrades the spectrum, so the presence of additional lead shielding may not have altered the absorbed dose substantially.

Table 5 presents the daily exposure levels used in GCM-4, GCM-8, and GCM-12 and indicates which levels were incorporated in each study. Levels of $270 \mathrm{R} / \mathrm{d}$ and above, used only in GCM-4, were carried out in the high-level $\gamma$-ray room under conditions comparable to those used in the low-level $\gamma$-ray room. 


\subsubsection{Animals}

GCM-4. The LAF 1 mouse was chosen for this study after an evaluation by Sacher and Grahn of a number of candidate strains and hybrids with regard to availability and known characteristics about disease susceptibility, tumor propensities, and life expectancy. The $\mathrm{LAF}_{1}$ was selected for reasons of cost, commercial availability, and its known favorable attributes for long-term study. It was the mouse of choice for the NCI studies in the 1940s and for the studies on the effects of weapons-quality radiations performed at Eniwetok (Operation Greenhouse) in April to May 1951 (Upton et al. 1960). The LAF 1 mice were bred at the Jackson Laboratory and shipped to Argonne (on a biweekly basis) when about seven weeks of age. Entry was nominally at 14 weeks or $100 \mathrm{~d}$ of age. Both sexes were used in equal numbers, and sample sizes per exposure level are given in Table 6 . Replication 1 was entered November 18, 1954.

GCM-8. Although GCM-4 took precedence, it was possible to introduce adequate samples of four inbred strains (A/Jax, BALB/c, C3Hf/He, C57BL/6) and the B6C/CB6 $\mathrm{F}_{1}$ and $\mathrm{F}_{2}$ generations from the reciprocal crosses of $\mathrm{BALB} / \mathrm{c}$ and $\mathrm{C57BL} / 6$. These were chosen as parent strains, as they represented the available extremes in radiation sensitivity, as judged by $\mathrm{LD}_{50 / 30}$ values. $\mathrm{BALB} / \mathrm{c}$ was sensitive $\left(\mathrm{LD}_{50}=500 \pm 7 \mathrm{R}\right)$; $\mathrm{C} 57 \mathrm{BL} / 6$ was resistant $\left(\mathrm{LD}_{50}=630 \pm 4 \mathrm{R}\right)$. Less regular samples were entered for strains $\mathrm{A} / \mathrm{He}$ and $\mathrm{C} 57 \mathrm{~L}$. The latter started late and continued into the GCM-12 study period. Age at entry was about $100 \pm 15 \mathrm{~d}$, and equal numbers of both sexes were used (Table 6).

All of the entrants for GCM-8 were bred at ANL. Because of space and sampling limitations, the GCM-8 study did not fully duplicate GCM-4. The GCM-4 experiment included 15 daily dose levels between 5 and $220 \mathrm{R} / \mathrm{d}$ in the low-level $\gamma$-ray room (the limiting doses in the facility in 1954-1958); GCM-8 regularly used only 10 levels between 12 and $220 \mathrm{R} / \mathrm{d}$ (Table 6).

GCM-12. Three inbred strains and an $F_{1}$ hybrid were used in this study, which was initiated in the summer of 1958 . The strains were the $\mathrm{A} / \mathrm{Jax}, \mathrm{BALB} / \mathrm{c}, \mathrm{C} 57 \mathrm{BL} / 6$, and the $\mathrm{C} 57 \mathrm{BL} / 6 \times \mathrm{BALB} / \mathrm{c} \mathrm{F}_{1}\left(\mathrm{~B} 6 \mathrm{CF}_{1}\right)$. Age at entry was approximately $100 \pm 15 \mathrm{~d}$, and both sexes were used in approximately equal numbers. All mice were bred at Argonne. Strain C57L was originally included in the records of GCM-12 but was not a part of the experimental design. These data on the C57L can be considered an extension of GCM-8. The data for the C57L have been transferred from the GCM-12 file to the GCM-8 file (Table A.4). Changes in the format vere made to accominodate the transfer. Data from the GCM-12 file can be identified by their project and experiment codes, which differ from those of GCM-8. Cage positions in the gamma room were renumbered for GCM-12, so inconsistencies exist within dose levels for such data. The numb srs of mice employed for each exposure level and sex are given in Table 7 . 


\subsubsection{Animal Husbandry}

With a few exceptions (to be noted), the mice in all three studies were housed in cylindrical cages modeled after a 2 -qt $(1.9-\mathrm{L})$ liquid container. The cages were made of a transparent Bakelite, 5 in. $(12.7 \mathrm{~cm})$ in internal diameter and 6.25 in. $(15.9 \mathrm{~cm})$ deep. A perforated stainless-steel cage top held a 5-oz (0.15-L) water bottle and pelleted food retained by a steel screen. The cage top was $2.5 \mathrm{in} .(6.4 \mathrm{~cm})$ deep, approximately half of which was inside the cage. The remaining space for the mice was approximately $100 \mathrm{in} .{ }^{3}\left(1600 \mathrm{~cm}^{3}\right)$. Three inches of sterile wood shavings were usually used for bedding, into which the mice always burrowed. Three mice were placed in each cage at"entry into the exposure field.

The cage top was slightly modified for the GCM-12 study by inserting a barrier in the food-bin portion to maintain an open section (approximately 4 in. ${ }^{2}\left[25.8 \mathrm{~cm}^{2}\right]$ ) to improve ventilation. The exceptions to the use of the cylindrical cage were for the one-third of the GCM-4 controls that were held in a shoe-box plastic cage (nine per cage) in a regular animal room, and the mice exposed to $0.3 \mathrm{R} / \mathrm{d}$ in the GCM-12 study, which were also kept in a shoebox cage (12 per cage). Controls were held in the maze/corridor of the $\gamma$-ray room where the environment was nearly identical to that in the exposure room itself. Death checks were made routinely - twice daily during the week and once daily on weekends.

At high daily doses, where survival was less than $14 \mathrm{~d}$, irradiations were performed in the high-level room by using a kilocurie source. Exposure conditions and housing were the same as those used in the low-level room. Death checks were more frequent at high doses. With survival times of $7 \mathrm{~d}$ or less, checks were performed at 12-, 4-, or 1-h intervals, depending on mean survival time (Sacher and Grahn 1964).

Cages were changed at least once weekly, more often if conditions required. Intercurrent infection was not a consistent problem in GCM-4 and GCM-8, but it was not entirely absent. Not all strains adapted well to the small cylindrical cage. Strain C3Hf did poorly, largely because of poor ventilation. Strains more sensitive to bacterial infection (A strains and $\mathrm{BALB} / \mathrm{c}$ ) may have suffered shorter survival times at the higher dose levels that severely damaged the hematopoietic system. Although cage conditions for GCM-4 and GCM-8 were not ideal for all strains of mice, they were much improved for the GCM-12 experiment because of the increased ventilation.

As noted previously, daily exposure levels, sample sizes, and mouse strains or hybrids employed are all given in Tables 5, 6, and 7. The C57L strain was entered late into the GCM-8 study and was included only in replications 72-90 (the last replication). Strain A/He was also entered later than the main body of entries and involved replications 40-90. All other strains were entered in replications 1-89.

\subsubsection{Data Recorded}

In all of these studies, the primary observation was survival time or day of death measured from the start of irradiation. While some mice were sacrificed in a clearly 
moribund state, the majority died of "natural causes." Gross pathologic findings at death were recorded for most animals, and uncertainties were checked by histologic evaluation. Lesions present at death were coded and are part of the permanent record. For GCM-4 and GCM-8, the record is limited to 21 pathology codes: nine for the most common neoplastic diseases and six each for the most prevalent acute or chronic infectious and degenerative diseases. The GCM-12 pathology record was more complete, and eight additional codes were added. These codes have all been translated into equivalent JANUS MACRO codes to permit full intercomparisons (Table C.3).

Though limited, the pathology data accommodated the majority of lesions then considered of primary value for differentiating "cause of death" or "major contributors" to an animal's death. For GCM-4 and GCM-8, the pathology record is "complete" for all doses between 0 and $56 \mathrm{R} / \mathrm{d}$. No file record is available at the higher doses where acute and subacute hematopoietic system damage prevailed, though some autopsies were performed to confirm the presence of acute and subacute marrow damage. A pathology record is available at all dose levels in GCM-12.

For all three studies, there are additional data in the file. Appendix A contains the complete format for all files. For GCM-4, age at entry was always $100 \mathrm{~d}$, and body weight data were taken at four weeks and two weeks before entry and on the day of entry. Cage, replication, and cage position (rack, shelf, and position on shelf) in the room are in the data file. There were three control groups: A (rack 20), in the corridor of the $\gamma$-ray room; $B$ (rack 21), in a nearby standard mouse room (A and B mice were caged in the cylindrical $\gamma$-ray room cage, three per unit); and $C$ (rack 22 ), in a mouse room with $B$ but in shoe-box cages, nine per cage. Investigators are cautioned that the different cage environments led to marked differences in survival time and life-table parameters.

The GCM-8 file contains the same basic data as in GCM-4 with regard to body weights, cage position, and replication. Age at entry is entered as the exact age (varying between about 80 and $120 \mathrm{~d}$ ). In addition, the mating number and parity for the specific mouse are in the data file, as is a coat-color code for the $F_{2}$ generation where five coat colors segregated out. Since most entries were a pair of cages (one of each sex at a given dose), the paired cage number is also given.

For GCM-12, the file format changes slightly because the animals moved from stockcage holding status to experimental status in a manner that ties the pre-irradiation history to the exposure history by use of a common stock cage number. Cages of 12 were held under routine observation from weaning (at about $30 \mathrm{~d}$ ) to time of entry (approximately $100 \mathrm{~d}$ ), and the data are recorded in File No. 94 (Appendix A, Table A.11). Stock cages were divided into four $\gamma$-ray-room cages of three mice, keeping the same stock cage number and adding a subcage number (1-4). There was only one body weight taken at entry. Age at entry, mating number and parity, and cage position are in the file as in GCM-8.

We did not integrate the files for GCM-12 (Table A.5) and for pre-experimental stock cage history (Table A.11), but this can easily be done by use of the common cage number and 
then the mouse number, mating number, and parity. Table A.11 also has the exact birth date (month, day, and year).

Control cages for GCM-8 did not have a fixed cage position, as they generally were held in the corridor/maze along with other controls and mice being held for studies of age dependence (GCM-9A), on a space-available basis. GCM-12 controls were assigned a specific cage position, however.

Lastly, although GCM-4 and GCM-8 were concurrent, GCM-4 was the primary study and had more exposure levels than the GCM-8 study. Dose levels of $49,64,85$, and $145 \mathrm{R} / \mathrm{d}$ were added about a year after the start, to provide more detail in the responses to acute and subacute injury and to the initial occurrence of deaths from neoplastic disease, principally lethal thymic lymphoma. The availability of cage positions at these doses was limited, but the two A strains were exposed to 64 and $85 \mathrm{R} / \mathrm{d}$ in GCM-8, with adequate sample sizes of 24 mice per sex, dose, and strain. A few (three per sex) BALB/c mice were entered at these two levels, but the data can be ignored.

\subsubsection{General Findings}

The results of these three studies were used in a number of articles and formed the basis for some new concepts and considerations in radiation toxicology. Data from the GCM-4 study were reported more concisely than those from the other two studies and addressed the then-existing controversies in the field of chronic radiation injury. The following paragraphs present some of the findings and principal references.

GCM-4. The two principal references are Sacher and Grahn (1964), for the lethality data, and Lesher et al. (1965), for the pathology data. The Sacher and Grahn article was largely prepared by Sacher and is a tour de force on chronic radiation injury theory and modeling. Users of any of the GCM data must read this report. It destroys the simplistic Blair theory of irreparable injury, lays out basic principles of interspecies extrapolation, discusses both the hormesis and wasted radiation issues sensibly, and offers hypotheses. The article emphasizes the need for good mathematical modeling that can be related to physiologic and cellular parameters. It notes that injury is not instantaneous and urges that more attention be given to the rise time of injury, as well as to the recovery time (injury and repair conform to an algebraic parabolic function). At least four ways of expressing the lifeshortening constant are also offered. The data brought out the presence of a half-dozen syndromes, including several not previously seen.

The pathology article (Lesher et al. 1965) was undistinguished. The dose-time distribution of the principal tumors and degenerative lesions was given in terms of the number of events per 50- or 100-d intervals. Life-table analyses were not used. A first effort was made to examine tumor multiplicity and the presence or absence of associations. For

males, the major tumors were lymphoid, pulmonary, and liver; for females, notable frequencies of ovarian and mammary tumors also occurred. Amyloidosis was common at 
lower doses ( $\leq 24 \mathrm{R} / \mathrm{d}$ ), as was degenerative kidney disease. The absence of life-table analyses makes interpretation difficult. These data need reanalysis.

GCM-8. Unfortunately, the data from the GCM-8 study were never completely reported. The major findings on life shortening were incorporated into several reports on the influence of genetic variables in radiation toxicity (Grahn 1958b, 1960), and on the analytical approaches to interspecies modeling (Grahn 1970; Grahn et al. 1978). A number of other analyses were performed, including an effort at data transformation to enhance the extraction of both phenotypic and genetic variances.

Some of the findings are summarized here. As a preface, we note again that the different strains did not thrive with equal success in the small cylindrical cage. Intercurrent infection and higher-than-desirable humidity levels reduced life expectancies in diseasesusceptible strains. Animal husbandry was the same at all dose levels, so any specific detrimental factor probably influenced survival values consistently within a strain. Although GCM-8 and GCM-12 are to a degree a continuous study, they cannot be compared or combined without careful examination of the GCM-8 life tables for inconsistencies or perturbations possibly induced by infectious disease. For example, control MAS values in GCM-8 were similar to those in GCM-12 for the A/Jax and BCF 1 but were $60-70 \mathrm{~d}$ shorter in GCM-8 for C57BL and 170-190 d shorter for the BALB/c. These represent $10 \%$ and $42 \%$ losses in mean life expectancy for the two strains, respectively. The differences are highly significant $(p<0.001)$ for BALB/c and borderline $(p=0.06-0.13)$ for the C57BL/6 strain.

The basic life-shortening coefficient expressed as a fraction of the control MAS days lost per roentgen per day is 0.037 , which equals $0.037 \mathrm{~d} / \mathrm{R}$, or approximately $0.04 \mathrm{~d} / \mathrm{rad}$. This value is consistent for all strains and hybrids throughout GCM-8 and GCM-12 (Grahn et al. 1978). The genetic variance is principally in the control life expectancy and in the pattern of specific causes of death, not in the life-shortening coefficient. Heritability of life expectancy, as derived from the estimated environmental and phenotypic variances of the two parent strains and their $F_{1}$ and $F_{2}$ hybrids in GCM-8, varied from 0.1 to 0.9 among 10 dose levels between 12 and $220 \mathrm{R} / \mathrm{d}$. There was no correlation between dose level and the heritability estimate, which averaged 0.625 across all doses.

Control MAS values for the radioresistant strain C3Hf were $36 \%$ shorter in GCM-8 than XAM-3, probably attributable to the difference in caging. C3Hf mice did not thrive in the small cylindrical cage as compared with their behavior in the larger shoe-box cage used in XAM-3. Nevertheless, the radiation-induced life-shortening coefficient was 0.035 , similar to that seen for other strains and hybrids. This suggested that the intrinsic life-shortening parameter will prevail even under poor environmental conditions.

The pathology data are in the record, but no full analysis was done. Strains like C57BL/6 with high frequencies of induced thymic lymphoma showed predictable perturbations from otherwise monotonic responses. Decrementation of the life tables for lymphoreticular tumor mortality would enhance the analysis of the residual causes of death or comparison with other strains. High frequencies of amyloidosis in some strains (A and 
C57L) compete with tumor mortality late in life and may obscure the occurrence of tumors at low doses. At the higher dose levels $(\geq 74 \mathrm{R} / \mathrm{d})$, where hematopoietic factors are paramount, substantial genetic variance is apparent in MAS values, suggesting an important genetic control of bone marrow injury and repair processes.

GCM-12. The data from this study, the last major long-term study that preceded the JANUS program, were used in many articles that dealt with issues as diverse as gerontology and radiation safety standards in space flight. The major results are in Grahn (1970), Grahn et al. (1972a, 1978), and Sacher et al. (1970). Portions of the data are selectively used in Grahn (1969), Sacher (1970, 1976, 1977), and Norris et al. (1976). The study also provided an experimental baseline and methodological standards for the JANUS program.

Two findings from the GCM-12 data are of some importance in the field of occupational and population radiation safety. First, the data demonstrated unequivocally that most ( $>85 \%$ ) radiation-induced excess risk of mortality at low doses could be attributed to neoplastic disease. In general terms, for the mouse, this would be for doses that induced less than $15 \%$ life shortening, or less than $6 \mathrm{R} / \mathrm{d}$ in this study. For humans, this would roughly extrapolate to less than $0.2 \mathrm{R} / \mathrm{d}$.

Second, induced life shortening in days per roentgen is linearly and additively a function of accumulated dose and is independent of instantaneous dose rate up to daily doses of $12 \mathrm{R} / \mathrm{d}$. Above this level, life shortening per roentgen begins to rise rapidly as increasing dose rate becomes a more dominant factor. For the mouse (and again independent of genotype), the parameter is $3.1 \mathrm{~d}$ lost per $100 \mathrm{R}$ (90 rad, $0.9 \mathrm{~Gy}$ ) of accumulated dose delivered at $12 \mathrm{R} / \mathrm{d}$ or less (Grahn et al. 1978). We conclude that this constant rate of loss of life is also almost entirely a function of excess deaths from neoplastic disease. This pattern should logically extrapolate down to the zero dose intercept.

The pathologic findings from the GCM-12 experiment permitted a more extensive analytical treatment than done for previous studies. Results of some of these analyses can be found in the previously cited reports. In brief terms, the following interpretations were developed.

1. Integrated lifetime lung tumor risk rises exponentially with daily dose level, but very little excess risk was seen at $0.3 \mathrm{R} / \mathrm{d}$.

2. Ovarian tumors and cysts do not appear in excess of control before about $500 \mathrm{~d}$ of exposure. The response saturates at the same level for doses of $6 \mathrm{R} / \mathrm{d}$ and below, with an exception at $0.3 \mathrm{R} / \mathrm{d}$ where there may be a threshold (no excess) until nearly $1000 \mathrm{~d}$ of exposure.

3. A negative relationship exists between lymphoreticular tumors and renal lesions. The latter reflect the incidence of amyloid degeneration, and this lesion appears to suppress the appearance of reticular tissue neoplasms. 
4. Lymphoreticular tumors involving the thymus are expressed rapidly (within the first several hundred days of exposure) at the high daily doses of 24,32 , and $43 \mathrm{R} / \mathrm{d}$. The response is transitional at $12 \mathrm{R} / \mathrm{d}$. From $6 \mathrm{R} / \mathrm{d}$ and below, non-thymic tumors are the general rule, and they increase in a total-dose and daily-dose dependent manner beyond the first year of exposure.

5. Liver tumors were not a major finding, though some excess was seen at doses below $6 \mathrm{R} / \mathrm{d}$. The strains involved in the GCM-12 study are not characterized by a marked frequency of liver tumors.

6. Because of the high nonlinear excess of lymphoreticular tumors, much analysis was done on leukemia-decremented data. This procedure permitted more orderly analysis of lifetime risks and a more compatible baseline for interspecies extrapolation models.

7. Life-table analyses of all deaths with one or more tumors for the three inbreds and the $\mathrm{BCF}_{1}$ supported the interpretation that the relative risk model is the better approach to long-term risk analysis. In these data, excess deaths with tumor varied by a factor of 4 to 5 among the four stocks, but differences in relative risk at low daily doses $(\leq 12 \mathrm{R} / \mathrm{d})$ averaged less than 1.0-1.5.

\subsubsection{Adjunct Studies to GCM-4}

The GCM-4 study was the centerpiece for a series of related studies. These other studies, all principally employing the $\mathrm{LAF}_{1}$, the same caging and husbandry, and comparable radiation procedures, were identified as follows.

GCM-5. This was a sacrifice series. Mice were exposed to selected GCM-4 dose levels and were removed from the field at predetermined post-irradiation times and sacrificed for detailed hematologic and cell turnover studies. The data are not available in a card-image file.

GCM-9. This was the primary study of the dependence of response (MAS) on age at exposure to selected daily-dose levels. See Section 3.3 for further details.

GAM-2. This was a single-dose study employing 13 doses between 150 and $1100 \mathrm{R}$ of $\gamma$ rays. The study was integrated with GFM-1, which included, in addition to five single doses common to GAM-2, the use of the split-dose procedure with eight different intervals between the two doses. See Section 3.4 for further details. 


\subsection{EXPERIMENT GCM-9}

\subsubsection{Background}

The possibility that the level of response could be influenced by age at exposure had not been extensively considered in the early studies. Most of the concern focused on the young adult as the individual to be protected in occupational situations. The Manhattan Project changed that viewpoint. The GCM-9 study addressed the question, "Does radiosensitivity vary significantly as a function of age at exposure or at initiation of protracted or periodic exposures?"

The file has been divided into two separate components identified as GCM-9A (Appendix A, Table A.6) and GCM-9B (Appendix A, Table A.7). GCM-9A contains the data for the pre-irradiation period for only $\mathrm{LAF}_{1}$ mice. Component $9 \mathrm{~B}$ contains the postirradiation survival data for the $\mathrm{LAF}_{1}$ plus the limited data from seven additional strains or hybrids.

\subsubsection{Experimental Design}

\subsubsection{Radiation Variables}

All exposure conditions were the same as those used in GCM-4. Dose levels of 170 , $125,97,74,43$, and $12 \mathrm{R} / \mathrm{d}$ were used for exposures of the $\mathrm{LAF} \mathrm{F}_{1}$, though the lowest dose was only employed at two age levels: 550 and $650 \mathrm{~d}$. Table 8 presents the sample sizes by sex and dose for the $\mathrm{LAF}_{1}$. Table 9 gives the sample sizes and exposure levels for the other mouse stocks employed and the general range of ages at entry. Locations in the radiation field were shared with animals in the GCM-4 and GCM-8 studies.

\subsubsection{Animals}

As noted, the $\mathrm{LAF}_{1}$ hybrid was the principal animal employed (Table 8). Several of the regular inbred strains and the $\mathrm{BCF}_{1}$ hybrid also were entered into the study, and these are identified in Table 9 . The study continued sporadically into the early $1960 \mathrm{~s}$.

\subsubsection{Animal Husbandry}

Caging and other husbandry factors were identical to those in the GCM-4 and GCM-8 studies. After 1958, the regular inbreds and the $\mathrm{BCF}_{1}$ were maintained, before irradiation, as in the GCM-12 experiment. 


\subsubsection{Data Recorded}

Survival time and major pathologic findings at death were routinely recorded; however, the pathology data were never entered into the original card-image file and are now unavailable. All of the survival data are available in this file. The ages at entry for the $\mathrm{LAF}_{1}$ are given in Table 8. A complete set of survival data is available for the six age groups between 250 and $800 \mathrm{~d}$ and the five daily doses between 43 and $170 \mathrm{R} / \mathrm{d}$. The baseline responses at $100 \mathrm{~d}$ of age are the data from experiments GCM-4 and GCM-8. Change in MAS from start of irradiation, relative to the MAS for the 100-d age group, was used as the measure of change in radioresistance.

\subsubsection{General Findings}

One summary report was published by Sacher et al. (1958). With the 100-d GCM-4 values as the starting point, resistance (post-irradiation MAS) increased up to the 400-d age level for all dose groups except at $43 \mathrm{R} / \mathrm{d}$. Beyond $400 \mathrm{~d}$ of age, resistance tended to diminish steadily, though the MAS remained above or at the 100-d value until 650-725 d of age. At $43 \mathrm{R} / \mathrm{d}$, resistance tended to diminish for all age groups, though this was irregular at 250 and $400 \mathrm{~d}$ of age. Note that the baseline MAS at $43 \mathrm{R} / \mathrm{d}$ was $150 \mathrm{~d}$, so an increased age at first exposure substantially increased the probability of the MAS being reduced simply by the normal dying-out process.

These data require complete reanalysis, and the nearly $1500 \mathrm{LAF}_{1}$ mice under observation before exposure (GCM-9A) should be considered as a control population supplementary to that from GCM-4. The data derived from the several inbreds and the BCF are limited in terms of sample size and age range, but they may provide some added support to the general findings from the $\mathrm{LAF}_{1}$ data.

\subsection{EXPERIMENTS GAM-2 AND GFM-1}

\subsubsection{Background}

The single-dose test (the exposure of young adult animals to brief high-dose-rate exposures in the acute lethal dose range) was the ultimate baseline study in the 1940s and 1950s. The derived $\mathrm{LD}_{50 / 30}$ dose was an accepted standard for laboratory animal studies. It tested hematopoietic system response to acute injury in clear and unequivocal terms. The response was self-limiting ( $30 \mathrm{~d}$ in most mammals and $60 \mathrm{~d}$ in humans), and survivors moved into a chronic injury mode within $60 \mathrm{~d}$ (at least in the mouse), when lymphoreticular neoplasms began to appear. The similarities between man and mouse were abundant.

Magnitude of injury and time to recovery of the hematopoietic system were critical parameters for therapeutic intervention and protection procedures. The use of paired-dose, split-dose, or protracted-dose procedures to estimate the injury and repair parameters was 
common. We chose the split-dose method (i.e., a given single dose would be divided into two equal portions, and the time between the two exposures would be varied so as to provide a basis for estimating recovery rates).

\subsubsection{Experimental Design}

\subsubsection{Radiation Variables}

The same basic radiation procedures were used for these two studies as for GCM-4. Single doses of ${ }^{60} \mathrm{Co} \gamma$ rays were delivered over a period of approximately $1 \mathrm{~h}$ in the highlevel $\gamma$-ray room. Dose was controlled by varying the distance from a nominally $1200-\mathrm{Ci}$ source. Aninals were exposed in their cylindrical home cages. GAM-2 (Appendix A, Table A.8) used 13 single doses: $150,300,450,600,700,750,800,850,900,950,1000,1050$, and $1100 \mathrm{R}$ (in air). GFM-1 (Table A.8) used five doses: 150, 300, 450, 600, and $750 \mathrm{R}$. The doses of 450 and 750 were used for the split-dose test, which employed nine intervals between the two half-doses of 225 and $375 \mathrm{R}$. The intervals, in d, were 0 (a single dose), 0.125 ( $3 \mathrm{~h}$ ), 0.4 (about $10 \mathrm{~h}$ ), 1, 3, 5, 7, 14, and 28. To randomize any potential influence of age differences at time of exposure for the longer intervals, three different starting times were used: day 0 ( $100 \mathrm{~d}$ of age), day 14, and day 28. Table 10 gives the number of animals exposed at each single-dose and split-dose interval.

\subsubsection{Animals}

These two conjoint studies were restricted to the $\mathrm{LAF}_{1}$, and entries into the experiment were drawn from the regular shipments on a generally random basis. GAM-2 required 6 replications, and GFM-1 was done in 10 replications. Entry age was the nominal $100 \mathrm{~d}$.

\subsubsection{Animal Husbandry}

Animal care procedures were the same as for GCM-4; and after irradiation, the animals were held for long-term observation in one of the regular animal holding rooms.

\subsubsection{Data Recorded}

As in the other concurrent studies, survival time and major pathologic findings at death were routinely recorded. All of the pathology data are in the file. Thus, complete survival and pathology data are available on the LAF 1 for GCM-4, GAM-2, and GFM-1, which were done concurrently. A common control (that for GCM-4) was employed for these three studies plus that portion of the GCM-9 (component 9B) study that used the LAF ${ }_{1}$. 


\subsubsection{General Findings}

The $\mathrm{LD}_{50 / 30}$ value for the two sexes combined was about $975 \mathrm{R}$, compared with $630 \mathrm{R}$ for $200-k V p$ x-rays. Life shortening induced by the single $\gamma$-ray exposures was about $18 \mathrm{~d} / 100 \mathrm{R}$ for males and $25 \mathrm{~d} / 100 \mathrm{R}$ for females. These values reflect a relative biological effectiveness for ${ }^{60} \mathrm{Co} \gamma$ rays of about $0.6-0.7$ compared with $200-\mathrm{kVp}$ x-rays. The XAM-3 experiment showed a 28-d life shortening for males exposed to midlethal single doses.

The split-dose procedure had no significant influence on either overall life shortening or on the incidence of lymphoreticular tumors, principally thymic lymphomas. The two dose levels (450 and $750 \mathrm{R}$ ) were differentiated and dose dependent in their responses; but within each dose level, the nine different intervals between dose increments did not influence the two noted endpoints. The two dose increments acted additively (Grahn and Sacher 1968). Portions of these data were used by Grahn et al. (1972a) in a comparative analysis of the effects of single versus protracted exposures. An important finding was that for exposure levels at or below the $\mathrm{LD}_{50}$, excess mortality among survivors of the acute syndrome was attributable to neoplastic disease, as was seen for mice exposed to low daily doses of $\gamma$ rays. For the $\mathrm{LAF}_{1}$ exposed to single doses when compared with those exposed to low daily doses, a protraction factor of about 5 was seen for both life shortening and excess mortality from lymphoreticular tumors. No specific results have been reported for other neoplastic or degenerative diseases.

\subsection{EXPERIMENT XAM-6}

\subsubsection{Background}

This was a follow-on experiment to XAM-3, which had studied acute and chronic mortality following single doses of $200-\mathrm{kVp}$ x-rays limited to the acute lethal dose range (about 0.8-1.2 of an $\mathrm{LD}_{50}$ dose). XAM-6 (Appendix A, Table A.9) studied the response to sublethal single doses, to bring the dose-response curve for life shortening into the low-dose range. The purpose was to improve the estimation of the regression coefficient at sublethal doses and to provide a broad, multistrain database for extrapolation to exposures below $100 \mathrm{R}$.

\subsubsection{Experimental Design}

\subsubsection{Radiation Variables}

All exposure procedures, the dosimetry, and the radiation source were the same as those used in experiment XAM-3. Exposure levels were 0,100 R, and a level equal to 0.6 of the $\mathrm{LD}_{50}$ for each of four inbred strains and the $\mathrm{BCF}_{1}$. The specific levels for the different strains were BALB/c, $300 \mathrm{R}$; A/He, $335 \mathrm{R}$; C3Hf/He, $355 \mathrm{R}$; C57BL/6, $380 \mathrm{R}$; $\mathrm{B}_{6 \mathrm{CF}}$, $395 \mathrm{R}$. 
These levels were based on $\mathrm{LD}_{50}$ values published in Grahn and Hamilton (1957) and Grahn (1958a).

\subsubsection{Animals}

As noted above, the mice chosen for this study were the inbred strains $\mathrm{A} / \mathrm{He}$, $\mathrm{BALB} / \mathrm{c}, \mathrm{C} 3 \mathrm{Hf} / \mathrm{He}$, and $\mathrm{C} 57 \mathrm{BL} / 6$, and the $\mathrm{F}_{1}$ hybrid $\mathrm{B}_{6 \mathrm{CF}}$. Strain $\mathrm{A} / \mathrm{He}$ was used in place of the AJax strain because the latter was committed to the GCM-12 experiment, and the A strains were not prolific breeders. The two strains were essentially identical in their responses (Grahn and Hamilton 1957). Equal numbers of both sexes were used at an entry age of approximately $85 \mathrm{~d}$. Table 11 provides the strain by dose matrix and sample sizes.

\subsubsection{Animal Husbandry}

The animals were housed in the standard plastic cage used for mice (12 per cage). Food and water were always available. After irradiation, the cages were moved to a regular animal holding room in the BIM animal facilities. They were kept in the same cage into which they had been weaned at about $30 \mathrm{~d}$ of age. The 12 mice were randomly assigned to the three dose levels of $0,100 \mathrm{R}$, and $0.6 \mathrm{LD}_{50}$, so there were four mice per dose per cage. No unusual husbandry methods were used.

\subsubsection{Data Recorded}

The mice entering the XAM-6 study were under pre-irradiation surveillance from the time of weaning, as they were part of the management procedure described in the Pre-experimental Stock Cage Records (Appendix A, Table A.11). Entries began in September 1958, and finished in June 1961. Survival time and major pathologic findings at death were routinely recorded. Pathology records are not complete, but the available record is in the file.

\subsubsection{General Findings}

The results of this study were never completely analyzed or reported. Between three and four dozen mice were used for each sex by strain by dose $(2 \times 5 \times 3)$ subgroup, except for the $\mathrm{BALB} / \mathrm{c}$ where only about 18 mice were entered per subgroup (Table 11). A disturbing feature was that, except for the BALB/c female, every control group had a shorter MAS from time of entry than that observed in the XAM-3 study. The deficit in MAS values ranged from about 20 to $180 \mathrm{~d}$ and averaged about $80 \mathrm{~d}$, or $15 \%$ of the average control MAS. All comparisons, therefore, had to be internal and could not use the equivalent of colony controls.

All female groups showed a substantial life-shortening effect at $100 \mathrm{R}$, averaging about $0.8 \mathrm{~d} / \mathrm{R}$. This life shortening was accompanied by a twofold to tenfold increase in the frequency of ovarian turnors and cysts. Between $100 \mathrm{R}$ and the $0.6 \mathrm{LD}_{50}$ dose, life shortening was further increased but by only one-fifth the amount per roentgen as seen between 0 and 
$100 \mathrm{R}$. This abrupt increase in life shortening at $100 \mathrm{R}$ and its relationship to the metabolic disruptions associated with induced ovarian dysfunction had been seen and discussed by Sacher (1956a) and Grahn (1960) in several separate experiments.

The males showed no life-shortening response at $100 \mathrm{R}$, except for a loss of $7 \mathrm{~d}$ for the $\mathrm{BCF}_{1}$ ( $1 \%$ of the control MAS). The inbred strains all had slight increases in MAS at $100 \mathrm{R}$ over their control, but the values ranged from only 9 to $19 \mathrm{~d}$; none was statistically significant. The loss between $100 \mathrm{R}$ and the $0.6 \mathrm{LD}_{50}$ dose was more typical for males, a loss of $0.3 \mathrm{~d} / \mathrm{R}$ (Grahn 1960; Grahn and Sacher 1968).

Regarding tumor frequency, there were, as noted, sharp increases in the frequency of ovarian tumors at $100 \mathrm{R}$. Depending on the specific strain sensitivities, there was some increase in frequency of lymphoreticular, pulmonary, and liver tumors. There was a generally consistent, though small, increase in the frequency of "all other" tumors (involving the mammary glands, kidneys, adrenal glands, pituitary, and connective tissues). Thus, in spite of minimal or no life shortening, some tumor occurrences were increased slightly at $100 \mathrm{R}$. The data at the $0.6 \mathrm{LD}_{50}$ dose need to be analyzed with life-table statistics to correct for age variation in time of tumor occurrence as a result of the higher exposure level and greater life shortening.

\subsection{EXPERIMENT XAM-7}

\subsubsection{Background}

This study was also a follow-on to the XAM-3 experiment, and it also tied into the XAM-6 study. XAM-7 (Appendix A, Table A.10) evaluated the effect of age at time of exposure to single doses of $200-k V p$ x-rays. The age variable was studied in the GCM-9 experiment by using daily exposures to $\gamma$ rays, but the influence of age on the response to single doses was not a part of the earlier studies. Three ages were used: 40, 300, and $500 \mathrm{~d}$ at time of exposure.

\subsubsection{Experimental Design}

\subsubsection{Radiation Variables}

Exposure procedures, dosimetry, and radiation source were identical to those used for the XAM-3 and XAM- 6 studies. Two exposure levels were used, 100 and $450 \mathrm{R}$, in addition to the control. The 100-R level was also used in XAM- 6 where age at exposure was approximately $85 \mathrm{~d}$. 


\subsubsection{Animals}

Three inbred strains were employed: $\mathrm{A} / \mathrm{He}, \mathrm{C} 3 \mathrm{Hf} / \mathrm{He}$, and $\mathrm{C57BL} / 6$. Most of the data are from the $\mathrm{A}$ and $\mathrm{C} 3 \mathrm{Hf}$ strains. Table 12 gives the number of animals entered into the study at each age and dose level for the three strains.

Generally, equal numbers of both sexes were used, though intervening mortality before the time of exposure made it impossible to maintain equality. Initially, the effort focused on the 0 vs. 100-R comparisons, and the 450-R exposures were entered during the second half of the period over which the 51 replications were entered. The first replication was entered in April 1960 and the last in August 1964.

Although this was not a large experiment, the numbers in Table 12 underestimate what might be considered the total entries, because every cage that ultimately entered the study can be considered as a "control" from weaning (about $30 \mathrm{~d}$ of age) until actual entry.

\subsubsection{Animal Husbandry}

There were no unusual husbandry procedures employed. The animals came from the stock holdings. Cages of 12 were set up at weaning and would be assigned into this or other experiments at the appropriate age. The standard plastic "mouse" cage was used, and food and water were always available. Cages were cleaned weekly. After irradiation, the cages were moved to a standard animal-holding room in the BIM animal facilities. In this study, the 12 mice per cage were always divided randomly into four controls and eight irradiated, either 100- or 450-R, but nor both, exposure levels. When fewer than 12 survived to the age at entry, the survivors were assigned at the ratio of one control to two irradiated.

\subsubsection{Data Recorded}

As noted, the animals were under observation from the time of weaning until entry into the experiment, as a control population, and this continued into the experimental period. Survival time and major pathologic findings at death were recorded, but the pathology file record is incomplete.

\subsubsection{General Findings}

As for the XAM-6 study, the results of XAM-7 were never fully analyzed or published. Even now, a full analysis will require the pre-irradiation data to be merged into this file from the Pre-experimental Stock Cage Record (Appendix A, Table A.11) so the mean after-expectations of life can be calculated more precisely. Intervening mortality was about $23 \%$ in strain $\mathrm{A} / \mathrm{He}$ before the $500-\mathrm{d}$ time of entry. It was only $7 \%$ in the $\mathrm{C} 3 \mathrm{Hf} / \mathrm{He}$.

Strain C3Hf/He provided a full matrix of ages, doses, and sexes. Life shortening averaged $34 \mathrm{~d} / 100 R$ for both sexes exposed at $40 \mathrm{~d}$ and $9 \mathrm{~d} / 100 \mathrm{R}$ at $500 \mathrm{~d}$, when measured 
across the three dose levels. For both sexes at $300 \mathrm{~d}$ of age, the average loss of life was $31 \mathrm{~d} / 100 \mathrm{R}$ at $450 \mathrm{R}$; but at $100 \mathrm{R}$, the average MAS increased by $28 \mathrm{~d}$. In other words, at $300 \mathrm{~d}$ the response was typical for the young adult.

Ovarian dysfunction may not have been an important factor in this study, as there was little difference between the two sexes. For the older females, this may have been due to the lack of a sufficient latency period when the entry ages are as late as 300 and $500 \mathrm{~d}$, in contrast to responses at about $100 \mathrm{~d}$ (see XAM-3 and XAM-6). At $450 \mathrm{R}$, both sexes of strain $\mathrm{A} / \mathrm{He}$ had mean losses of life between 9 and $19 \mathrm{~d} / 100 \mathrm{R}$ at 300 and $500 \mathrm{~d}$ of age at exposure. At $100 \mathrm{R}$, both sexes had small increases in MAS at $300 \mathrm{~d}$ and small losses in MAS at $500 \mathrm{~d}$.

In summary, for both strains and sexes, there was no consistent response to the single dose of $100 \mathrm{R}$, but there was a consistent life-shortening response to $450 \mathrm{R}$ at all ages at exposure. This again indicates the existence of a nonlinear dose-response equation over the 0 to 100 to $450 \mathrm{R}$ range. This type of nonlinear response was also seen for the males in the XAM-6 study. In the absence of any summary of the pathologic findings, we hesitate to argue for the existence of a threshold dose, even for the advanced ages of exposure. As was seen in XAM-6, there can be subtle increases in the occurrence of neoplastic disease even in the absence of a clear life-shortening effect. 


\section{RECORDS MANAGEMENT}

\subsection{INTRODUCTION}

The description of the XAM-3 study noted that we maintained a number of inbred mouse strains, outcross generations, and genetic marker stocks of mice in the BIM animal facilities. These are all identified in Appendix B. Procedures were established in mid 1953 for maintaining the records of the breeding colony and of the experiments in a permanent, machine-readable form. At that time, the available machine calculation capability was primarily through the use of IBM accounting equipment in the ANL Accounting Department. All records were therefore designed to conform to the requirement of easy transfer to IBM cards for storage and analysis. Cards were printed specifically to accommodate our needs, which were diverse. Some final card-image records, for example, required the collation and calculation of data from two or three basic data cards. As computers evolved, the card files were converted to magnetic tape files; these, in turn, have been transferred to laser-read hard disk files. Data tapes were regularly replicated and were stored in a controlled-temperature, fireproof vault. Thus, 40-year-old records have been well preserved.

The basic animal records in the present database consist of three files. The first two are the Mating Record (Appendix A, Table A.12) and the Litter Record (Appendix A, Table A.13). Both records run from early 1953 to late 1969, when the records were stopped because of funding constraints. The original written mating records and the pedigree books are still in the archives in Building 202, ANL. Thus, on an as-needed basis, these two files could be brought up to the date of the final dissolution of the colony in October 1987.

The third file is a more limited record of the mice from six inbred strains and the $\mathrm{B} \mathrm{CF}_{1}$ hybrid. This is the Pre-experimental Stock Cage Record (Appendix A, Table A.11), which records the history of the mice from weaning until they were assigned to an experiment, to a mating, or were discarded. This file runs from mid 1958 to late 1969 and contains a record on over 32,000 animals.

Although the data in these three files can be easily accessed for statistical analyses, which has been done on a selective basis, the files are principally stock records and not an integral part of any specific experiment. The files are described in statements that are not in the format of preceding descriptions of individual experiments. Some indication of the results of analyses that have been or could be done will be presented, however.

\subsection{RECORD DESCRIPTIONS}

\subsubsection{Mating Record}

The Mating Record contains the identification data for all matings that maintained the inbred strains, outcrosses, and genetic marker stocks. The record gives the strain of both 
the sire and the dam separately to accommodate outcross matings. Other pertinent features of the record are in Table A.12. It is important to note that the dates of mating and of discard are both given, along with the reason for discard. These items could be critical in any study of reproductive performance.

The Mating Record can be cross-referenced to the Litter Record, which contains data on litters born between May 1953 and October 1969. Since a mating will appear in the litter record only if it has produced at least one litter, the frequency of sterile or otherwise nonproductive matings must be obtained by collating the mating and litter records for the strains of interest. A full match of the two records appears to exist for all pertinent mating numbers through 5331 (all matings set up through April 1969). The litter record is incomplete for the balance of the mating record. The handwritten mating record continues to mating number 8396, which was discarded in October 1987.

\subsubsection{Litter Record}

This Litter Record (Appendix A, Table A.13) may well be unique in the history and annals of mouse genetics. The uniqueness rests on the fact that all newborn mice were sexed at birth, or within several days of birth, and daily monitoring created a record of deaths by sex and age. This record was then summarized for the permanent card-image record into three age intervals: $0-5,6-15$, and $16 \mathrm{~d}$ to weaning (which was generally at $25-30 \mathrm{~d}$ of age). The record includes data on over 21,000 litters.

The information in this file includes basic information on the litter (strain, dam, sire, mating number, and parity), the number born and date born, and the number weaned and date weaned. The number born and weaned by sex and the survival record by age and sex are also included, along with the age of the dam on the date of birth of the litter. Some gross pathologic examinations would have been done as required to maintain proper surveillance for infectious or nutritional problems. Such information is not in the file, however.

We note here that the existence of this record was principally due to the interest, diligence, and skill of K.F. Hamilton (later, K.F.H. Allen), who worked with the colony and the principal investigator, D. Grahn, from 1953 until 1974, and with the JANUS Program from 1971 until her retirement in 1980. She came to Argonne from the Jackson Laboratory in 1949, where she had been employed since graduation from Mt. Holyoke College in 1945.

To facilitate the use of the mating record and litter record files, we have combined the two files into an additional file for the archive - Combined Mating and Litter Records 1953-1969 (Appendix A, Table A.14). The Mating Record has been entered into the Litter Record, and the two have been made compatible with regard to the strain designation for both sire and dam. The Mating Record is entered at the beginning of the specific mating's Litter Record, if any litters were produced, and is listed with a parity of 00 . The three dates in the Mating Record (dam's birth date, mating date, and discard date) and reason for discard are added to the Litter Record in additional columns so that this file goes beyond the usual 80-column card-image format. 
The combined file simplifies the assessment of the reproductive performance of a strain because all nonproductive matings are listed with productive matings. The availability of the discard date and reason for discard provides a definitive duration for each productive mating. The separate files are kept in the archive for basic record keeping and for easy use when the larger combined file would not be needed.

The litter record has been used periodically to evaluate the breeding performance of the different strains and hybrids and to measure whether there had been any inadvertent outcrossing or spontaneous genetic change that might have altered the characteristics of a strain. Outcrossing is easy to detect simply by evaluating litter size and other variables such as preweaning mortality. According to analyses done through the late 1960s, there had been no changes in the reproductive characteristics of the primary inbred strains.

Some of the results of these analyses were published in a National Institutes of Health document that summarized discussions at a workshop on model systems for the study of aging (Grahn 1972). Previously, a comparison of one inbred (BALB/c), one outcross $\left(\mathrm{BC} / \mathrm{CBF}_{2}\right)$, and the U.S. population demonstrated the similarity of neonatal, infant, and childhood death rates for the two species (Grahn 1963). A few general findings can be presented here.

1. Most of the early mortality occurs in the first five days after birth (generally equivalent to neonatal deaths in humans). There is little sex difference in mortality, but there is significant variation among strains. The neonatal death rate increases with maternal age (and parity), but death rates between 6 and $30 \mathrm{~d}$ seem to be less influenced by age of dam or strain. Neonatal mortality is highest in small litters (less than the mean for the strain) and drops to its minimum values at litter sizes greater than the mean.

2. Mean litter size, which varies significantly among strains, rises in some strains to a peak value at maternal ages of 100 to $200 \mathrm{~d}$. Thereafter, litter size drops rapidly with age. In some strains, the A strains for example, the maximum mean litter size occurs in first litters and drops steadily with increasing age and parity.

3. Interval between litters doubles from a mean value of about 25 to 50 d, as maternal age rises from 50 to $400 \mathrm{~d}$. Between 100 and $300 \mathrm{~d}$, the interval remains quite steady; however, this record is for singlepair matings with the sire left in the cage at all times (all matings for production purposes and for maintenance of the strains were single-pair, full-sib matings).

4. There was a remarkable degree of uniformity or invariance within strains for such measures as neonatal mortality and mean litter size when viewed across calendar time from 1953 to 1967 . Strain 
differences persist but with little variance related to calendar time or season of the year.

5. By summarizing across 14 inbred strains and four genetic marker stocks, the average mortality rate from birth to day 5 varies between 0.033 and $0.175 / \mathrm{d}$. The factor of $5(0.175 / 0.033)$ has a large genetic component, but a proper analysis would have to control the influence of parity, litter size, maternal age, and possibly litter interval. These are, unfortunately, concomitant and confounded variables. The mortality rates per day between 6 and $15 \mathrm{~d}$ continue to show a range among the genotypes of about 5 to 1 , but the observed rates drop to $0.002-0.009 / \mathrm{d}$. Between 16 and $30 \mathrm{~d}$, the rates vary from 0.001 to $0.004 / \mathrm{d}$. By about $100 \mathrm{~d}$ of age, the mortality rate for most strains has dropped to $2 \times 10^{-4} / \mathrm{d}$ or less. Hybrid and outcross generations have much lower death rates from birth and on. They may start at about $0.02 / \mathrm{d}$ between birth and five days and drop to $1 \times 10^{-5} / \mathrm{d}$ at $100 \mathrm{~d}$. An inventory of the number of litters in this file for each of the inbred strains, marker stocks, and hybrid generations is given in Table 13. Of the nearly 22,000 individual litter records, most (64\%) involve the six principal inbreds and the $\mathrm{B}^{-C_{1}} \mathrm{~F}_{1}$. Thirteen percent concern the nine ISU strains, $8 \%$ involve the four ISU marker stocks, $7 \%$ concern the backcross series from the $\mathrm{BCF}_{1}$ to the $\mathrm{BALB} / \mathrm{c}$ parent, and the remainder involve a range of outcross or mutant stocks.

\subsection{PRE-EXPERIMENTAL STOCK CAGE RECORD}

As experiments GCM-4 and GCM-8 neared completion, a decision was made in 1957, on the basis of the accruing data, to discontinue the use of the $\mathrm{LAF}_{1}$ as the principal mouse for the long-term studies. It was less expensive at that time to produce our own animals, and the data on the $\mathrm{B} \mathrm{CF} \mathrm{F}_{1}$ showed it to be a favorable replacement for the $\mathrm{LAF}_{1}$. We also agreed to supplement the future studies by using additional inbred strains with the two parent lines $\mathrm{BALB} / \mathrm{c}$ and $\mathrm{C57BL} / 6$ being obvious first choices.

It was decided that the six primary inbreds (A/He, A/Jax, BALB/c, C3Hf/He, C57BL/6, C57L) and the $\mathrm{F}_{1}$ hybrid from the cross of the C57BL/6 female with the BALB/c male (the $\mathrm{B}_{6} \mathrm{CF}_{1}$ ) would make up a standardized pre-experimental stock colony. This accumulation of stock mice began in June 1958. It continued until November 1969, when preparations for the JANUS Program precluded the need. Only $\mathrm{B}_{6 \mathrm{CF}}$ mice were used for the JANUS studies, and they were all produced at the BIM animal facilities from caesareanderived, barrier-sustained BALB/c and C57BL/6 inbred stocks that were obtained from D. Grahn's holdings in BIM. Continuity of animal backgrounds was thus assured. No experimental work was done in the JANUS program with the two inbred parent lines, however. 
Beginning in mid-1958, the six inbred strains and the $\mathrm{B} \mathrm{CF}_{1}$ were routinely weaned into stock cages. These were the standard plastic cages used for housing mice. The cage dimensions (outside) were $8 \times 18 \times 5.5$ in. $(20.3 \times 45.7 \times 14 \mathrm{~cm})$ (width, depth, height). The inside (floor) dimensions were $7 \times 16 \times 5$ in. $(17.8 \times 40.6 \times 12.7 \mathrm{~cm})$. A stainless-steel top contained a food bin and held an 8-0z (0.24-L) water bottle. The stock cage provided ample space for 12 mice. This number was chosen to simplify the transfer of animals from their stock status to any experimental status that employed the small, cylindrical $\gamma$-ray-room cage holding three mice each. To ensure continuity of record, the stock cage number was carried into any experimental protocol. If four small cages of three were to be used, a single digit subcage number was added.

The contents of this file are given in Appendix A, Table A.11. The usual basic identifiers are present (strain, sex, animal number, mating number, and parity) plus the birth date and the exit date. The exit date is the actual date the animal was entered into an experiment, was placed in mating, was discarded, died, or turned up missing (see exit codes). A survival time is given, which in this record is the actual age of the mouse on the day it left the stock-cage status for any of the reasons noted above.

If a mouse died before exiting to another use, pathology codes may be in the record, though the record is incomplete.

As time passed, there were fewer demands for animals. By 1965 and on, the majority were being discarded. Nevertheless, the record was completed to the date of discard, including the survival time (age), which was usually at 100 or more days of age.

This database has had only minimal use and that involved the estimation of lifetable values for the $\mathrm{B} \mathrm{CF}_{1}$ between 30 and $100 \mathrm{~d}$ of age (Grahn 1970; Sacher et al. 1970). Such estimates may have also been made for some of the inbred strains, but there is no clear record. The post-weaning life table for juvenile and young adult mice can be readily generated from this file, but the removal of mice for breeding purposes, discard, or other uses must be carefully censored.

Though pathology data are not complete, there are enough to indicate what was occurring during this age period when death rates are at or approaching their minimum. For the $\mathrm{B} 6 \mathrm{CF}_{1}$, this rate is about $1.3 \times 10^{-5}$ /mouse-day at $100 \mathrm{~d}$ of age. The first occurrence of spontaneous lymphoreticular tumors can be identified in these data as well. A thymic lymphoma occurred in a $\mathrm{B} \mathrm{CF}_{1}$ male at $47 \mathrm{~d}$ of age and at $69 \mathrm{~d}$ of age in a C57BL/6 male. In other strains, early tumors begin to appear by $90-100 \mathrm{~d}$.

The possibilities for analysis of the juvenile and young adult life table can be judged from Table 14. Altogether, there are about $2.25 \times 10^{6}$ mouse-days at risk, though the number per sex and strain varies from a low of about 93,000 to a high of about 340,000 , assuming each mouse was at risk for $70 \mathrm{~d}$.

This file also can be merged or linked to the Litter Record (Appendix A, Table A.13) and/or to any experimental survival record such as GCM-12, for example. The common 
identifiers are strain, mating number, and parity for all files. The Litter Record and the Pre-experimental Stock Record also have the date of birth in the file. The experimental and pre-experimental records have a common cage number as well as animal number within strain. It is thus possible to link, for example, the late-life performance of any animal or group of animals to the early post-natal history of the siblings (littermates and nonlittermates). 


\section{REFERENCES}

Brues, A.M., and G.A. Sacher, 1952, Analysis of mammalian radiation injury and lethality, in Symposium on Radiobiology (J.J. Nickson, editor), J. Wiley \& Sons, New York, pp. 441-465.

Festing, M.F.W., 1975, International Index of Laboratory Animals (M.F.W. Festing, editor), Medical Research Council, Laboratory Animals Centre, Carshalton, U.K.

Gowen, J.W., 1963, Genetics of infectious diseases, in Methodology in Mammalian Genetics (W.J. Burdette, editor), Holden-Day, Inc., San Francisco, pp. 383-404.

Grahn, D., 1958a, Acute radiation response of mice from a cross between radiosensitive and radioresistant strains, Genetics 43:835-843.

Grahn, D., 1958b, The genetic factor in acute and chronic radiation toxicity, in Proceedings of the 2nd United Nations International Conference on Peaceful Uses of Atomic Energy, vol. 22, United Nations, New York, pp. 394-399.

Grahn, D., 1960, Genetic control of physiological processes: the genetics of radiation toxicity in animals, in Radioisotopes in the Biosphere (R.S. Caldecott and L.A. Snyder, editors), University of Minnesota Press, Minneapolis, pp. 181-200.

Grahn, D., 1963, Mammalian radiation genetics, in Methodology in Mammalian Genetics (W.J. Burdette, editor), Holden-Day, Inc., San Francisco, pp. 127-155.

Grahn, D., 1969, Late effects of external irradiations in animals and the prediction of lowdose effects, in Biological Implications of the Nuclear Age, U.S. Atomic Energy Commission, AEC Symposium Series 16, CONF 690303, Washington, D.C., pp. 269-281.

Grahn, D., 1970, Biological effects of protracted low dose radiation exposure of man and animals, in Late Effects of Radiation (R.J.M. Fry, D. Grahn, M.L. Griem, and J.H. Rust, editors), Taylor and Francis, Ltd., London, pp. 101-136.

Grahn, D., 1972, Data collection and genetic analysis in the selection and study of rodent model systems in aging, in Development of the Rodent as a Model System of Aging (D.C. Gibson, editor), National Institute of Child Health and Human Development, DHEW pub. no. (NIH)72-121, Bethesda, pp. 55-65.

Grahn, D., and K.F. Hamilton, 1957, Genetic variation in the acute lethal response of four inbred mouse strains to whole body x-irradiation, Genetics 42:189-198.

Grahn, D., and G.A. Sacher, 1968, Fractionation and protraction factors and the late effects of radiation in small mammals, in Dose Rate in Mammalian Radiation Biology, U.S. Atomic Energy Commission report CONF-680410, pp. 2.10-2.27. 
Grahn, D., K.F. Hamilton, and W. Leslie, 1962, Analysis of linkage between qualitative and quantitative traits in mice (abstract), Genetics 47:955-956.

Grahn, D., K.F. Hamilton, and W. Leslie, 1964, The genetic analysis of radiation sensitivity, in Annual Report 1964, Biological and Medical Research Division, Argonne National Laboratory report ANL-6971, pp. 125-128.

Grahn, D., R.J.M. Fry, and R.A. Lea, 1972a, Analysis of survival and cause of death statistics for mice under single and duration-of-life gamma irradiation. Life Sciences and Space Research X:175-186.

Grahn, D., E.J. Ainsworth, F.S. Williamson, and R.J.M. Fry, 1972b, A program to study fission neutron-induced chronic injury in cells, tissues and animal populations, utilizing the JANUS reactor of the Argonne National Laboratory, in Radiobiological Applications of Neutron Irradiation, International Atomic Energy Agency, Vienna, pp. 211-228.

Grahn, D., G.A. Sacher, R.A. Lea, R.J.M. Fry, and J.H. Rust, 1978, Analytical approaches and interpretations of data on time, rate and cause of death of mice exposed to external gamma irradiation, in Late Biological Effects of Ionizing Radiation, International Atomic Energy Agency, Vienna, pp. 43-58.

Green, E.L., 1966, Biology of the Laboratory Mouse, 2nd ed. (E.L. Green, editor). McGraw-Hill Book Co., New York.

Green, M.C., 1966, Mutant genes and linkages, in Biology of the Laboratory Mouse, 2nd Edition (E.L. Green, editor), McGraw-Hill Book Co., New York, pp. 87-150.

Jay, G.E., Jr., 1963, Genetic strains and stocks, in Methodology in Mammalian Genetics, (W.J. Burdette, editor), Holden-Day, Inc., San Francisco, pp. 83-123.

Lesher, S., G.A. Sacher, D. Grahn, K. Hamilton, and A. Sallese, 1965, Survival of mice under duration-of-life exposure to gamma rays. II. Pathologic effects. Radiation Research 24:239-277.

Lorenz, E., 1950, Some biologic effects of long continued irradiation, American Journal of Roentgenology and Radium Therapy LXIII:176-185.

Lorenz, E., W.E. Heston, A.B. Eschenbrenner, and M.K. Deringer, 1947, Biological studies in the tolerance range, Radiology 49:274-285.

Lorenz, E., A.B. Eschenbrenner, W.E. Heston, and D. Uphoff, 1951, Mammary tumor incidence in female $\mathrm{C} 3 \mathrm{Hb}$ mice following long-continued gamma irradiation, Journal of the National Cancer Institute 11:947-965. 
Lorenz, E., L.O. Jacobson, W.E. Heston, M. Shimkin, A.B. Eschenbrenner, M.K. Deringer, J. Doniger, and R. Schweisthal, 1954, Effects of long-continued total-body gamma irradiation on mice, guinea pigs, and rabbits. III. Effects on life span, weight, blood picture and carcinogenesis and the role of the intensity of radiation, in Biological Effects of External $X$ and Gamma Radiation, Part I (R.E. Zirkle, editor), National Nuclear Energy Series IV-22B, McGraw-Hill Book Co., New York, pp. 24-148.

Lorenz, E., J.W. Hollcroft, E. Miller, C.C. Congdon, and R. Schweisthal, 1955, Long-term effects of acute and chronic irradiation in mice. I. Survival and tumor incidence following chronic irradiation of $0.11 \mathrm{R}$ per day, Journal of the National Cancer Institute 15:1049-1058.

Norris, W.P., S.A. Tyler, and G.A. Sacher, 1976, An interspecies comparison of responses of mice and dogs to continuous ${ }^{60} \mathrm{Co} \gamma$-irradiation, in Proceedings of the International Symposium on Biological and Environmental Effects of Low Level Radiation, vol. I, International Atomic Energy Agency, Vienna, pp. 147-156.

Sacher, G.A., 1956a, On the statistical nature of mortality, with special reference to chronic radiation mortality, Radiology 67:250-258.

Sacher, G.A., 1956b, Survival of mice under duration-of-life exposure to $\mathrm{x}$-rays at various rates, in Biological Effects of External X and Gamma Radiation, part 2 (R.E. Zirkle, editor), National Nuclear Energy Series IV-22B, McGraw-Hill Book Co., New York, pp. 435-463 [originally issued as Manhattan District Report CH-3900, Metallurgical Laboratory, University of Chicago, April 1950).

Sacher, G.A., 1970, Models from radiation toxicity data, in Late Effects of Radiation (R.J.M. Fry, D. Grahn, M.L. Griem, and J.H. Rust, editors), Taylor and Francis, Ltd., London, pp. 233-244.

Sacher, G.A., 1976, Dose, dose rate, radiation quality, and host factors for radiation-induced life shortening, in Aging, Carcinogenesis, and Radiation Biology (K.C. Smith, editor), Plenum Press Corp., New York, pp. 493-517.

Sacher, G.A., 1977, Life table modification and life prolongation, in Handbook of the Biology of Aging (C.E. Finch and L. Hayflick, editors), Von Nostrand Reinhold Co., New York, pp. 582-638.

Sacher, G.A., and D. Grahn, 1964, Survival of mice under duration-of-life exposure to gamma rays. I. The dosage-survival relation and the lethality function, Journal of the National Cancer Institute 32:277-321.

Sacher, G.A., D. Grahn, and S. Lesher, 1958, The dependence of acute and subacute radiosensitivity on age in the $\mathrm{LAF}_{1}$ mouse, Biological and Medical Research Division Semi-Annual Report, Argonne National Laboratory report ANL-5916, pp. 84-86. 
Sacher, G.A., and D. Grahn, R.J.M. Fry, and J.H. Rust, 1970, Epidemiological and cellular effects of chronic radiation exposure: a search for relationship, in Proceedings of the First European Symposium on Late Effects of Radiation, Comitato Nazionale per l'Energia Nucleare, Roma, pp. 15-38.

Schott, R.G., 1932, The inheritance of resistance to Salmonella aertrycke in various strains of mice, Genetics 17:203-229.

Sinclair, W.K., 1963, Absorbed dose in biological specimens irradiated externally with cobalt-60 gamma radiation, Radiation Research 20:288-297.

Staats, J., 1968, Standardized nomenclature for inbred strains of mice: fourth listing, Cancer Research 28:391-240.

Staats, J., 1980, Standardized nomenclature for inbred strains of mice: seventh listing. Cancer Research 40:2083-2128.

Upton, A.C., A.W. Kimball, J. Furth, K.W. Christenberry, and W.H. Benedict, 1960, Some delayed effects of atomic-bomb radiations in mice, Cancer Research 20:1-60.

Webster, L.T., 1937, Inheritance of resistance of mice to enteric bacterial and neurotropic virus infections, Journal of Experimental Medicine 57:261-286. 
TABLE 1 Mean After-Survival Values for the NCI Initial Low-Dose Study

\begin{tabular}{|c|c|c|c|c|}
\hline $\begin{array}{l}\text { Dose } \\
\text { (R/d) }\end{array}$ & Sex & $n$ & $\begin{array}{l}\text { Age at } \\
\text { Entry (d) }\end{array}$ & $\mathrm{MAS} \pm \mathrm{SE}(\mathrm{d})$ \\
\hline \multirow[t]{3}{*}{0} & $\infty$ & 29 & 60 & $724.6 \pm 33.8$ \\
\hline & $q$ & 30 & 61 & $703.6 \pm 32.8$ \\
\hline & $\Sigma$ & 59 & 60 & $713.9 \pm 23.4$ \\
\hline \multirow[t]{3}{*}{0.11} & $\infty$ & 24 & 53 & $738.7 \pm 38.8$ \\
\hline & $q$ & 23 & 51 & $747.5 \pm 42.3$ \\
\hline & $\Sigma$ & 47 & 52 & $743.0 \pm 28.3$ \\
\hline \multirow[t]{3}{*}{1.1} & $\infty$ & 24 & 57 & $662.5 \pm 31.9$ \\
\hline & $q$ & 24 & 66 & $705.4 \pm 24.8$ \\
\hline & $\Sigma$ & 48 & 62 & $684.0 \pm 20.2$ \\
\hline \multirow[t]{3}{*}{2.2} & $\infty$ & 23 & 65 & $638.7 \pm 24.1$ \\
\hline & $q$ & 24 & 74 & $622.5 \pm 32.6$ \\
\hline & $\Sigma$ & 47 & 70 & $630.5 \pm 20.2$ \\
\hline \multirow[t]{3}{*}{4.4} & $\infty$ & 24 & 69 & $593.7 \pm 23.1$ \\
\hline & $q$ & 24 & 78 & $586.0 \pm 21.8$ \\
\hline & $\Sigma$ & 48 & 74 & $589.9 \pm 15.7$ \\
\hline \multirow[t]{3}{*}{8.8} & $\infty$ & 21 & 85 & $469.6 \pm 24.3$ \\
\hline & $q$ & 24 & 86 & $505.6 \pm 19.4$ \\
\hline & $\Sigma$ & 45 & 86 & $488.8 \pm 15.4$ \\
\hline
\end{tabular}


TABLE 2 Mean After-Survival Values for the NCI Low-Dose Follow-Up Study

\begin{tabular}{lcccc}
\hline $\begin{array}{c}\text { Dose } \\
\text { (R/d) }\end{array}$ & Sex & $n$ & $\begin{array}{c}\text { Age at } \\
\text { Entry (d) }\end{array}$ & MAS \pm SE (d) \\
\hline \multirow{2}{*}{0} & o & 110 & 31 & $652.5 \pm 14.3$ \\
& f & 116 & 31 & $771.9 \pm 16.1$ \\
& $\Sigma$ & 226 & 31 & $713.8 \pm 11.5$ \\
0.11 & o & 111 & 31 & $752.6 \pm 14.0$ \\
& o & 120 & 31 & $789.6 \pm 17.7$ \\
& $\Sigma$ & 223 & 31 & $771.8 \pm 11.4$ \\
\hline
\end{tabular}


TABLE 3 Distribution of Strains and Hybrids across the Single X-Ray Exposures Used in the XAM-3 Experiment

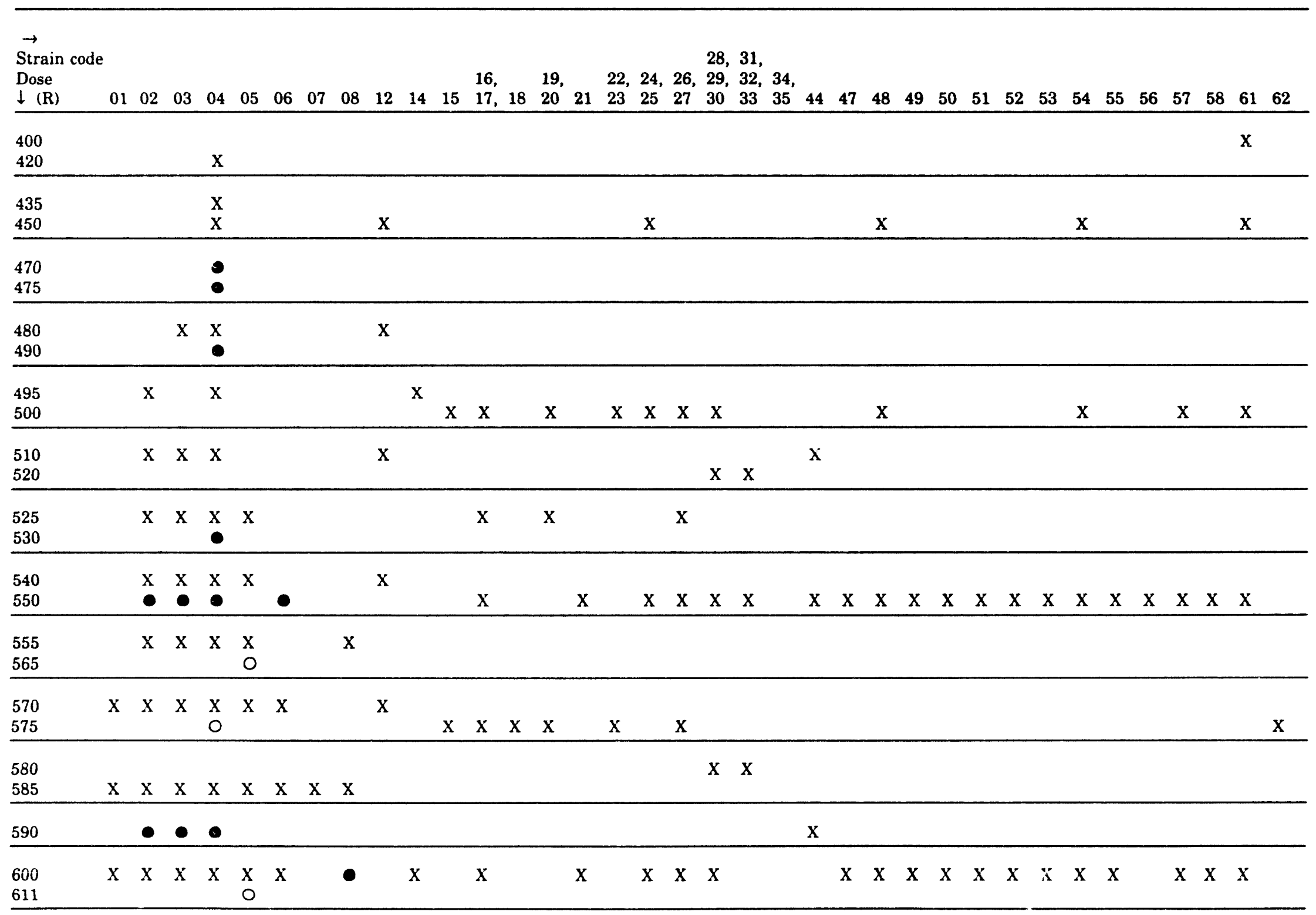




\section{TABLE 3 (Cont.)}

$\rightarrow$

Strain code

Dose

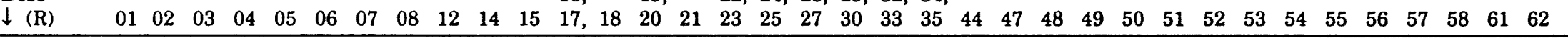

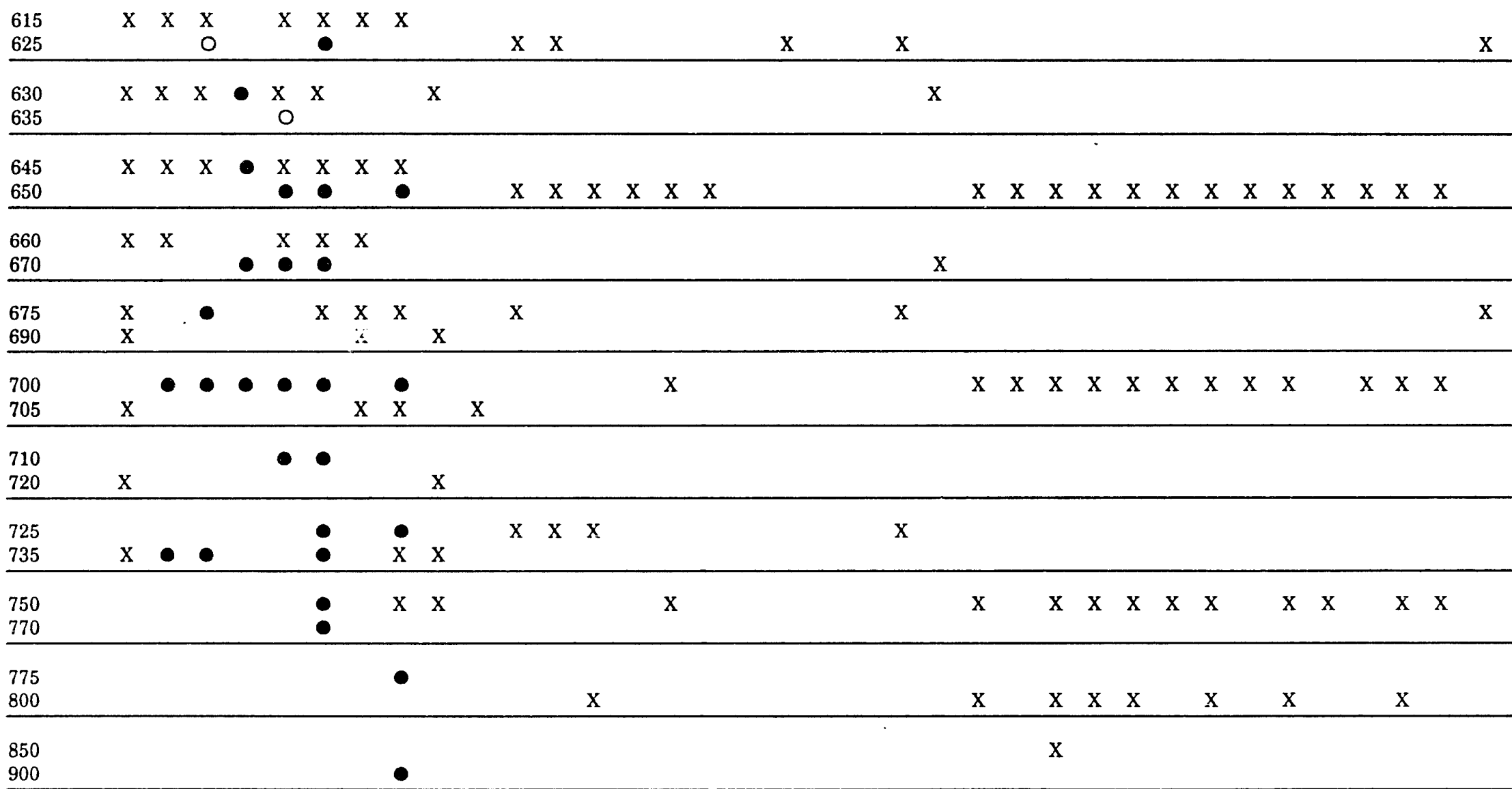

$\mathrm{X}=$ Principal tests

- Follow-on tests

$O=$ Preliminary tests (small samples; can be ignored or combined with nearest regular exposure level) 
TABLE 4 Number of Mice in XAM-3 Experiment by Strain, Hybrid, or Genetic Stock; Sexes and Doses Combined

\begin{tabular}{|c|c|c|c|c|}
\hline \multirow{2}{*}{$\begin{array}{l}\text { Strain } \\
\text { Code }\end{array}$} & \multirow{2}{*}{$\begin{array}{l}\text { Total } \\
\text { at All } \\
\text { Doses }\end{array}$} & \multicolumn{2}{|c|}{$\begin{array}{c}\text { Held for } \\
\text { Lifetime Study }^{a}\end{array}$} & \multirow[b]{2}{*}{ Other $^{b}$} \\
\hline & & Control & Irradiated & \\
\hline 01 & 337 & 2 & 144 & 191 \\
\hline 02 & 875 & 157 & 206 & 512 \\
\hline 03 & 966 & 150 & 211 & 605 \\
\hline 04 & 1,855 & 155 & 308 & 1,392 \\
\hline 05 & 1,389 & 166 & 426 & 797 \\
\hline 06 & 1,470 & 162 & 382 & 926 \\
\hline 07 & 673 & 115 & 294 & 264 \\
\hline 08 & 1,860 & 116 & 399 & 1,345 \\
\hline 12 & 1,014 & 209 & 0 & 805 \\
\hline 14 & 313 & 98 & 111 & 104 \\
\hline 15 & 1,709 & 189 & 303 & 1,217 \\
\hline 16 & 590 & 57 & 134 & 399 \\
\hline 17 & 925 & 88 & 227 & 610 \\
\hline 18 & 562 & 0 & 0 & 562 \\
\hline 19 & 399 & 112 & 45 & 242 \\
\hline 20 & 268 & 41 & 31 & 196 \\
\hline 21 & 98 & 0 & 0 & 98 \\
\hline 22 & 148 & 0 & 0 & 148 \\
\hline 23 & 175 & 0 & 0 & 175 \\
\hline 24 & 160 & 0 & 0 & 160 \\
\hline 25 & 189 & 0 & 0 & 189 \\
\hline 26 & 198 & 50 & 60 & 88 \\
\hline 27 & 260 & 94 & 106 & 60 \\
\hline 28 & 146 & 0 & 0 & 146 \\
\hline 29 & 145 & 0 & 0 & 145 \\
\hline 30 & 76 & 0 & 0 & 76 \\
\hline 31 & 32 & 0 & 0 & 32 \\
\hline 32 & 39 & 0 & 0 & 39 \\
\hline 33 & 49 & 0 & 0 & 49 \\
\hline 34 & 746 & 132 & 132 & 482 \\
\hline 35 & 710 & 160 & 130 & 420 \\
\hline 44 & 452 & 61 & 169 & 222 \\
\hline 47 & 496 & 120 & 127 & 249 \\
\hline 48 & 581 & 104 & 152 & 325 \\
\hline 49 & 552 & 102 & 267 & 183 \\
\hline 50 & 546 & 129 & 142 & 275 \\
\hline 51 & 543 & 116 & 165 & 262 \\
\hline 52 & 517 & 104 & 76 & 337 \\
\hline 53 & 497 & 105 & 138 & 254 \\
\hline 54 & 602 & 175 & 149 & 278 \\
\hline 55 & 588 & 95 & 260 & 233 \\
\hline 56 & 248 & 122 & 37 & 89 \\
\hline 57 & 319 & 103 & 91 & 125 \\
\hline
\end{tabular}


TABLE 4 (Cont.)

\begin{tabular}{|c|c|c|c|c|}
\hline \multirow{2}{*}{$\begin{array}{l}\text { Strain } \\
\text { Code }\end{array}$} & \multirow{2}{*}{$\begin{array}{l}\text { Total } \\
\text { at All } \\
\text { Doses }\end{array}$} & \multicolumn{2}{|c|}{$\begin{array}{c}\text { Held for } \\
\text { Lifetime Study } \\
\end{array}$} & \multirow[b]{2}{*}{ Other ${ }^{b}$} \\
\hline & & Control & Irradiated & \\
\hline 58 & 531 & 113 & 109 & 309 \\
\hline 61 & 629 & 139 & 138 & 352 \\
\hline 62 & 63 & 0 & 0 & 63 \\
\hline$\Sigma$ & 25,540 & 3,841 & 5,669 & 16,030 \\
\hline
\end{tabular}

a Number of mice surviving to $61 \mathrm{~d}$ or more after exposure and dying of natural causes.

b Number of mice dying of acute injury (0-30 d), missing, or discarded earlier than $60 \mathrm{~d}$ following exposure. 
TABLE 5 Distribution of Experiments GCM-4, 8, and 12 across Strains and Daily Dose Levels

\begin{tabular}{|c|c|c|c|c|c|c|c|c|c|}
\hline $\begin{array}{l}\text { Dose } \\
\text { (R/d) }\end{array}$ & $\mathrm{LAF}_{1}$ & $\mathrm{~A} / \mathrm{He}$ & A/Jax & BALB/c & $\mathrm{C} 3 \mathrm{Hf}$ & C57BL/6 & C57L & $\mathrm{BCF}_{1}$ & $\mathrm{BCF}_{2}$ \\
\hline 0 & 4 & - & 8,12 & 8,12 & 8 & 8,12 & 8,12 & 8,12 & 8 \\
\hline 0.3 & - & - & 12 & 12 & - & - & - & 12 & - \\
\hline 1.3 & - & - & 12 & 12 & - & 12 & - & 12 & - \\
\hline 2.6 & - & - & 12 & 12 & - & 12 & - & 12 & - \\
\hline 5 & 4 & - & - & 8 & - & 8 & - & - & - \\
\hline 6 & - & - & 12 & 12 & - & 12 & - & 12 & - \\
\hline 12 & 4 & 8 & 8,12 & 8,12 & 8 & 8,12 & 8,12 & 8,12 & 8 \\
\hline 24 & 4 & 8 & 8,12 & 8,12 & 8 & 8,12 & 8,12 & 8,12 & 8 \\
\hline 32 & 4 & 8 & 8,12 & 8,12 & 8 & 8,12 & 8,12 & 8,12 & 8 \\
\hline 43 & 4 & 8 & 8,12 & 8,12 & 8 & 8,12 & 8,12 & 8,12 & 8 \\
\hline 49 & 4 & - & - & - & - & - & - & - & - \\
\hline 56 & 4 & 8 & 8,12 & 8,12 & 8 & 8,12 & 8,12 & 8,12 & 8 \\
\hline 64 & 4 & 8 & 8 & $(8)^{a}$ & - & - & - & - & - \\
\hline 74 & 4 & 8 & 8 & 8 & 8 & 8 & 8,12 & 8 & 8 \\
\hline 85 & 4 & 8 & 8 & $(8)^{\mathrm{a}}$ & -- & - & - & - & - \\
\hline 97 & 4 & 8 & 8 & 8 & 8 & 8 & 8,12 & 8 & 8 \\
\hline 125 & 4 & 8 & 8 & 8 & 8 & 8 & 8,12 & 8 & 8 \\
\hline 145 & 4 & - & - & - & - & - & - & - & - \\
\hline 170 & 4 & 8 & 8 & 8 & 8 & 8 & 8 & 8 & 8 \\
\hline 220 & 4 & - & 8 & 8 & 8 & 8 & 8 & 8 & 8 \\
\hline 270 & 4 & - & - & - & - & - & - & - & - \\
\hline 330 & 4 & - & - & - & - & - & _ & - & - \\
\hline 410 & 4 & - & - & - & $\ldots$ & - & - & - & - \\
\hline 500 & 4 & - & - & - & - & - & _- & - & - \\
\hline 610 & 4 & - & - & - & - & - & - & - & - \\
\hline 750 & 4 & - & - & - & - & - & _- & - & _- \\
\hline 1100 & 4 & - & - & - & - & - & - & - & - \\
\hline 1650 & 4 & - & - & - & - & - & - & - & - \\
\hline 2500 & 4 & - & - & - & - & - & - & - & - \\
\hline
\end{tabular}

a Insufficient sample size; can be deleted. 
TABLE 6 Number of Mice Entered into Studies GCM-4 and GCM-8 According to Dose and Strain; Sexes Combined

\begin{tabular}{|c|c|c|c|c|c|c|c|c|c|}
\hline \multirow{2}{*}{$\begin{array}{l}\text { Dose } \\
(\mathrm{R} / \mathrm{d})\end{array}$} & \multirow{2}{*}{$\begin{array}{c}\begin{array}{c}\text { GCM-4 } \\
\text { Strain Code }\end{array} \\
01\end{array}$} & \multicolumn{8}{|c|}{$\begin{array}{c}\text { GCM-8 } \\
\text { Strain Codes }\end{array}$} \\
\hline & & 02 & 03 & 04 & 05 & 06 & 07 & 08 & 12 \\
\hline \multicolumn{10}{|l|}{0} \\
\hline$A^{a}$ & 180 & - & 103 & 137 & 129 & 121 & 41 & 105 & 112 \\
\hline$B^{b}$ & 180 & - & - & - & - & - & - & - & - \\
\hline $\mathrm{C}^{c}$ & 180 & - & - & - & _- & - & - & - & _ \\
\hline 5 & 240 & - & - & 66 & - & 60 & - & - & - \\
\hline 12 & 366 & 18 & 84 & 60 & 78 & 84 & 24 & 78 & 66 \\
\hline 24 & 366 & 18 & 84 & 66 & 78 & 87 & 24 & 84 & 74 \\
\hline 32 & 300 & 18 & 76 & 60 & 78 & 84 & 27 & 78 & 84 \\
\hline 43 & 300 & 18 & 84 & 66 & 83 & 83 & 24 & 78 & 84 \\
\hline 49 & 270 & - & - & - & - & - & 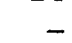 & - & - \\
\hline 56 & 240 & 48 & 60 & 48 & 54 & 57 & 30 & 60 & 60 \\
\hline 64 & 210 & 48 & 48 & 6 & - & - & - & - & - \\
\hline 74 & 210 & 48 & 60 & 53 & 60 & 57 & 30 & 60 & 60 \\
\hline 85 & 210 & 48 & 48 & 6 & - & - & - & - & - \\
\hline 97 & 210 & 48 & 60 & 53 & 60 & 60 & 24 & 60 & 60 \\
\hline 125 & 210 & 30 & 48 & 48 & 48 & 48 & 30 & 48 & 48 \\
\hline 145 & 210 & - & - & - & - & - & - & - & - \\
\hline 170 & 210 & 24 & 36 & 36 & 36 & 36 & 30 & 36 & 36 \\
\hline 220 & 150 & - & 24 & 24 & 24 & 24 & 18 & 24 & 24 \\
\hline $270^{d}$ & 60 & - & - & - & - & - & - & - & - \\
\hline 330 & 60 & - & - & - & - & - & - & - & _ \\
\hline 410 & 60 & - & - & - & - & - & - & - & _ \\
\hline 500 & 60 & - & - & - & - & - & - & - & _ \\
\hline 610 & 60 & - & - & - & - & - & - & - & _ \\
\hline 750 & 48 & - & - & - & - & - & - & - & - \\
\hline 1100 & 48 & - & - & - & - & - & _ & - & _ \\
\hline 1650 & 48 & - & - & - & - & - & - & - & _ \\
\hline 2500 & 18 & - & - & - & - & - & - & - & - \\
\hline Totals & 4704 & 366 & 815 & 729 & 728 & 801 & 302 & 711 & 708 \\
\hline
\end{tabular}

a Mice housed in cylindrical cages, three per cage, in corridor of $\gamma$ room.

b Mice housed in cylindrical cages, three per cage, in standard mouse room.

c Mice housed in shoe-box cages, nine per cage, in standard mouse room.

d Exposures of $270 \mathrm{R} / \mathrm{d}$ and above were performed in high-level $\gamma$ room. 
TABLE 7 Number of Mice Entered into the GCM-12 Study According to Dose, Strain, and Sex

\begin{tabular}{|c|c|c|c|c|c|c|c|c|c|c|}
\hline \multirow{3}{*}{$\begin{array}{l}\text { Dose } \\
(\mathrm{R} / \mathrm{d})\end{array}$} & \multicolumn{8}{|c|}{ GCM-12 } & \multirow{2}{*}{\multicolumn{2}{|c|}{$\begin{array}{c}\begin{array}{c}\text { GCM-8 } \\
\text { (continued) }\end{array} \\
\text { C57L } \\
\end{array}$}} \\
\hline & \multicolumn{2}{|c|}{ A/Jax } & \multicolumn{2}{|c|}{ BALB/c } & \multicolumn{2}{|c|}{ C57BL/6 } & \multicolumn{2}{|c|}{$\mathrm{B} 6 \mathrm{CF}_{1}$} & & \\
\hline & $\sigma^{*}$ & $q$ & $\sigma$ & f & $\sigma^{*}$ & ㅇ & $\sigma^{\prime}$ & q & $\infty$ & 우 \\
\hline 0 & 84 & 84 & 81 & 84 & 82 & 82 & 165 & 168 & 153 & 143 \\
\hline 0.3 & 60 & 57 & 60 & 60 & - & - & 120 & 119 & - & - \\
\hline 1.3 & 83 & 83 & 83 & 84 & 83 & 83 & 168 & 168 & - & - \\
\hline 2.6 & 47 & 48 & 48 & 48 & 48 & 48 & 96 & 96 & - & - \\
\hline 6.0 & 48 & 48 & 47 & 46 & 48 & 47 & 96 & 96 & - & - \\
\hline 12.0 & 46 & 47 & 46 & 46 & 46 & 45 & 48 & 48 & 48 & 48 \\
\hline 24.0 & 46 & 48 & 47 & 48 & 48 & 48 & 48 & 48 & 47 & 46 \\
\hline 32.0 & 24 & 24 & 24 & 23 & 24 & 23 & 24 & 24 & 36 & 24 \\
\hline 43.0 & 22 & 24 & 23 & 24 & 22 & 23 & 24 & 24 & 68 & 60 \\
\hline 56.0 & 24 & 24 & 23 & 24 & 24 & 22 & 23 & 24 & 72 & 36 \\
\hline 74.0 & - & - & - & - & - & - & - & - & 57 & 60 \\
\hline 97.0 & - & - & - & - & - & - & - & - & 72 & 36 \\
\hline 125.0 & - & - & - & - & - & - & - & - & 72 & 35 \\
\hline \multirow[t]{2}{*}{ Total } & 484 & 487 & 482 & 487 & 425 & 421 & 812 & 815 & 625 & 488 \\
\hline & \multicolumn{2}{|c|}{971} & \multicolumn{2}{|c|}{969} & \multicolumn{2}{|c|}{846} & \multicolumn{2}{|c|}{1627} & \multicolumn{2}{|c|}{1113} \\
\hline
\end{tabular}


TABLE 8 Number of LAF 1 Mice Entered in the GCM-9B Test of Age Dependence of Response to Daily Irradiation by ${ }^{60} \mathrm{Co} \gamma$ Rays (exposure levels as in GCM-4)

\begin{tabular}{|c|c|c|c|c|c|c|c|c|c|c|c|c|}
\hline \multirow{2}{*}{$\begin{array}{c}\mathrm{Age}^{\mathrm{a}} \\
\text { (d) }\end{array}$} & \multicolumn{2}{|c|}{$12 \mathrm{R} / \mathrm{d}$} & \multicolumn{2}{|c|}{$43 \mathrm{R} / \mathrm{d}$} & \multicolumn{2}{|c|}{$74 \mathrm{R} / \mathrm{d}$} & \multicolumn{2}{|c|}{$97 \mathrm{R} / \mathrm{d}$} & \multicolumn{2}{|c|}{$125 \mathrm{R} / \mathrm{d}$} & \multicolumn{2}{|c|}{$170 \mathrm{R} / \mathrm{d}$} \\
\hline & $\sigma^{n}$ & f & $\sigma^{*}$ & $f$ & $\sigma^{*}$ & 우 & $\sigma^{*}$ & $q$ & $\sigma^{x}$ & $f$ & $\sigma$ & q \\
\hline 250 & - & - & 15 & 15 & 12 & 12 & 12 & 12 & 9 & 9 & 6 & 6 \\
\hline 400 & - & - & 18 & 18 & 17 & 17 & 18 & 18 & 15 & 15 & 6 & 6 \\
\hline 550 & 12 & 18 & 9 & 9 & 9 & 9 & 9 & 9 & 9 & 9 & 6 & 6 \\
\hline 650 & 12 & 23 & 9 & 15 & 6 & 15 & 6 & 15 & 9 & 15 & 6 & 6 \\
\hline 725 & - & - & 8 & 11 & 5 & 7 & 6 & 9 & 7 & 9 & 6 & 6 \\
\hline 800 & - & - & 3 & 6 & 3 & 5 & 3 & 5 & 3 & 5 & - & 6 \\
\hline 850 & - & - & 3 & 9 & - & - & - & - & 5 & 6 & - & - \\
\hline 925 & - & - & - & 10 & - & - & - & - & - & 7 & - & - \\
\hline
\end{tabular}

a Age at entry. The 100-d baseline age group taken from GCM-4 (Table 6). 
TABLE 9 Number of Mice Entered in the GCM-9B Test of Age Dependence of Response to Daily Irradiation by ${ }^{60} \mathrm{Co} \gamma$ Rays

\begin{tabular}{|c|c|c|c|c|c|c|c|c|c|c|c|c|c|c|c|}
\hline \multirow[b]{2}{*}{ Strain } & \multicolumn{2}{|c|}{$43 \mathrm{R} / \mathrm{d}$} & \multicolumn{2}{|c|}{$56 \mathrm{R} / \mathrm{d}$} & \multicolumn{2}{|c|}{$85 \mathrm{R} / \mathrm{d}$} & \multicolumn{2}{|c|}{$97 \mathrm{R} / \mathrm{d}$} & \multicolumn{2}{|c|}{$125 \mathrm{R} / \mathrm{d}$} & \multicolumn{2}{|c|}{$145 \mathrm{R} / \mathrm{d}$} & \multicolumn{2}{|c|}{$170 \mathrm{R} / \mathrm{d}$} & \multirow{2}{*}{$\begin{array}{c}\text { Ages or Age } \\
\text { Range (d) }\end{array}$} \\
\hline & $\sigma^{*}$ & q & $\sigma^{*}$ & $q$ & $\sigma^{\circ}$ & $f$ & $\sigma^{\circ}$ & $q$ & $\sigma^{*}$ & $f$ & $\sigma^{*}$ & f & $\sigma^{*}$ & $q$ & \\
\hline $\mathrm{A} / \mathrm{He}$ & 12 & 12 & - & - & - & - & - & - & 12 & - & - & - & - & - & $250-400$ \\
\hline $\mathrm{A} / \mathrm{Jax}$ & 15 & 18 & - & 9 & - & 6 & - & - & 12 & 6 & 18 & 18 & 18 & 18 & $100,250-400$ \\
\hline BALB/c & 6 & 12 & - & - & - & - & 9 & 13 & 31 & 18 & 18 & 17 & - & - & $100,200-400$ \\
\hline C3Hf & 6 & 6 & - & - & - & - & - & - & 9 & - & - & - & - & - & 300 \\
\hline C57BL/6 & 12 & 11 & - & - & - & - & - & - & 21 & 6 & 12 & 12 & 12 & 12 & $\begin{array}{l}100,250-400 \\
550\end{array}$ \\
\hline $\mathrm{C57L}$ & 12 & 12 & - & - & - & - & - & - & - & - & - & - & & - & $250-400$ \\
\hline $\mathrm{BCF}_{1}$ & 8 & 8 & - & - & - & - & - & - & 8 & 6 & 24 & 24 & 41 & 41 & $\begin{array}{l}60,100 \\
250-400\end{array}$ \\
\hline
\end{tabular}




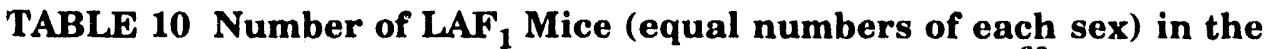
GAM-2/GFM-1 Test of Response to Single Exposures of ${ }^{60} \mathrm{Co} \gamma$ Rays at 100 Days of Age (GAM-2), Plus a Split-Dose Series at 450 and 750 R (GFM-1)

\begin{tabular}{|c|c|c|c|c|c|c|c|c|c|}
\hline \multirow{2}{*}{$\begin{array}{l}\text { Dose }^{a} \\
(R)\end{array}$} & \multicolumn{9}{|c|}{$\begin{array}{c}\text { Number of Mice Exposed at Each Interval between } \\
\text { the Two Equal Half-Doses: }\end{array}$} \\
\hline & $0 \mathrm{~d}$ & $0.125 \mathrm{~d}$ & $0.4 \mathrm{~d}$ & $1 \mathrm{~d}$ & $3 \mathrm{~d}$ & $5 \mathrm{~d}$ & $7 \mathrm{~d}$ & $14 \mathrm{~d}$ & $28 \mathrm{c}$ \\
\hline 150 & 108 & - & - & - & - & - & - & - & - \\
\hline 300 & 108 & - & - & - & - & - & - & - & - \\
\hline 450 & 108 & 54 & 54 & 54 & 54 & 54 & 54 & 54 & 54 \\
\hline 600 & 108 & - & - & - & - & - & - & - & - \\
\hline 700 & 54 & - & - & - & - & - & - & - & - \\
\hline 750 & 120 & 54 & 54 & 54 & 54 & 54 & 54 & 54 & 54 \\
\hline 800 & 54 & - & - & - & - & - & - & - & - \\
\hline 850 & 54 & - & - & - & - & - & - & - & - \\
\hline 900 & 54 & - & - & - & - & - & - & - & - \\
\hline 950 & 54 & - & - & - & - & - & - & - & - \\
\hline 1000 & 54 & - & - & - & - & - & - & - & - \\
\hline 1050 & 54 & - & - & - & - & - & - & - & - \\
\hline 1100 & 54 & - & - & - & - & - & - & - & - \\
\hline
\end{tabular}

a Dose of ${ }^{60} \mathrm{Co} \gamma$ rays; $3-20 \mathrm{R} / \mathrm{min}$; exposure period of about $55 \mathrm{~min}$.

b " 0 " interval equals a single dose. 
TABLE 11 Number of Mice for the XAM-6 Test of Life Shortening Induced at Doses below the XAM-3 Range of Approximately 0.8-1.2 $\mathrm{LD}_{50}$ Values $^{\mathrm{a}}$

\begin{tabular}{|c|c|c|c|c|c|c|c|c|c|c|}
\hline \multirow{2}{*}{$\begin{array}{c}\text { Dose } \\
(R, \text { in air })\end{array}$} & \multicolumn{2}{|c|}{ BALB/c } & \multicolumn{2}{|c|}{$\mathrm{A} / \mathrm{He}$} & \multicolumn{2}{|c|}{ C3Hf } & \multicolumn{2}{|c|}{$\mathrm{C} 57 \mathrm{BL} / 6$} & \multicolumn{2}{|c|}{$\mathrm{BCCF}_{1}$} \\
\hline & $\sigma$ & $q$ & $\sigma^{*}$ & 8 & $\sigma^{n}$ & f & $\alpha$ & $q$ & $\sigma^{\prime \prime}$ & $q$ \\
\hline 0 & 19 & 19 & 44 & 44 & 51 & 51 & 36 & 35 & 36 & 35 \\
\hline 100 & 20 & 20 & 44 & 44 & 52 & 52 & 36 & 36 & 36 & 37 \\
\hline $300^{b}$ & 19 & 20 & - & - & - & - & - & - & - & - \\
\hline $335^{b}$ & - & - & 44 & 43 & - & - & - & - & - & - \\
\hline $355^{\mathrm{b}}$ & - & - & - & - & 52 & 52 & - & - & - & - \\
\hline $380^{\mathrm{b}}$ & - & - & - & - & - & - & 36 & 36 & - & - \\
\hline $395^{\mathrm{b}}$ & - & - & - & - & - & - & - & - & 36 & 36 \\
\hline
\end{tabular}

a 200-kVp x-rays delivered at approximately $22 \mathrm{R} / \mathrm{min}$; age at entry about $100 \mathrm{~d}$.

b Exposure level chosen as approximately equal to $60 \%$ of the acute $\mathrm{LD}_{50}$ value for the given strain or hybrid. 
TABLE 12 Number of Mice for the XAM-7 Study of Age Dependence of Response to Single Doses of 200-kVp X-Rays below the Acute Lethal Level

\begin{tabular}{|c|c|c|c|c|c|c|c|c|c|c|c|c|c|c|c|c|}
\hline \multirow{3}{*}{$\begin{array}{c}\text { Age at } \\
\text { Entry } \\
\text { (d) }\end{array}$} & \multicolumn{6}{|c|}{$\mathrm{A} / \mathrm{He}$} & \multicolumn{6}{|c|}{$\mathrm{C} 3 \mathrm{Hf} / \mathrm{He}$} & \multicolumn{4}{|c|}{ C57BL/6 } \\
\hline & \multicolumn{2}{|c|}{$0 \mathrm{R}$} & \multicolumn{2}{|c|}{$100 \mathrm{R}$} & \multicolumn{2}{|c|}{$450 \mathrm{R}$} & \multicolumn{2}{|c|}{$0 \mathrm{R}$} & \multicolumn{2}{|c|}{$100 \mathrm{R}$} & \multicolumn{2}{|c|}{$450 \mathrm{R}$} & \multicolumn{2}{|c|}{$0 \mathrm{R}$} & \multicolumn{2}{|c|}{$100 \mathrm{R}$} \\
\hline & $\sigma$ & + & $\sigma$ & + & $\sigma$ & 9 & $0^{n}$ & q & $\sigma^{2}$ & q & $\sigma$ & $q$ & $\sigma$ & \& & $\sigma$ & † \\
\hline 40 & 7 & 7 & 12 & 14 & - & - & 41 & 40 & 54 & 54 & 30 & 31 & - & - & - & - \\
\hline 300 & 49 & 54 & 70 & 84 & 30 & 23 & 50 & 43 & 72 & 64 & 31 & 23 & 18 & 3 & 37 & 5 \\
\hline 500 & 34 & 61 & 53 & 64 & 20 & 56 & 60 & 45 & 89 & 45 & 30 & 32 & 8 & - & 18 & - \\
\hline
\end{tabular}


TABLE 13 Inventory of Litter Records

\begin{tabular}{lrrr}
\hline $\begin{array}{c}\text { Strain } \\
\text { Code }^{\mathrm{a}}\end{array}$ & $\begin{array}{c}\text { Number } \\
\text { of Litters }\end{array}$ & $\begin{array}{c}\text { Strain } \\
\text { Code }^{\mathrm{a}}\end{array}$ & $\begin{array}{c}\text { Number } \\
\text { of Litters }\end{array}$ \\
\hline 01 & 224 & 29 & 45 \\
02 & 2,013 & 30 & 30 \\
03 & 2,066 & 31 & 15 \\
04 & 2,172 & 32 & 14 \\
05 & 1,844 & 33 & 11 \\
06 & 2,402 & 34 & 100 \\
07 & 1,250 & 35 & 99 \\
08 & 1,918 & 37 & 6 \\
09 & 203 & 39 & 18 \\
10 & 29 & 41 & 20 \\
11 & 27 & 43 & 34 \\
12 & 125 & 44 & 430 \\
13 & 126 & 46 & 203 \\
14 & 53 & 47 & 272 \\
15 & 327 & 48 & 306 \\
16 & 131 & 49 & 328 \\
17 & 203 & 50 & 440 \\
18 & 90 & 51 & 233 \\
19 & 73 & 52 & 334 \\
20 & 60 & 53 & 338 \\
21 & 175 & 54 & 257 \\
22 & 39 & 55 & 212 \\
23 & 34 & 56 & 405 \\
24 & 46 & 57 & 394 \\
25 & 51 & 58 & 459 \\
26 & 54 & 61 & 453 \\
27 & 62 & 62 & 325 \\
28 & 46 & & \\
\hline
\end{tabular}

asee Appendix B. 
TABLE 14 Number of Animals Entered into the Pre-Experimental Stock Cage Record According to Strain and Sex

\begin{tabular}{crrr}
\hline Strain & Males & Females & Total \\
\hline 02 & 1,405 & 1,409 & 2,814 \\
03 & 1,805 & 1,737 & 3,542 \\
04 & 2,169 & 2,413 & 4,582 \\
05 & 2,086 & 1,937 & 4,023 \\
06 & 2,728 & 2,302 & 5,030 \\
07 & 1,438 & 1,327 & 2,765 \\
08 & 4,693 & 4,917 & 9,610 \\
Totals & 16,324 & 16,042 & 32,366 \\
\hline
\end{tabular}




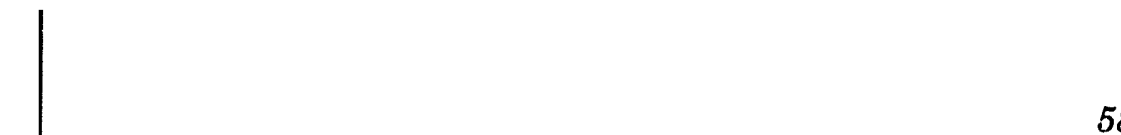


APPENDEX A:

FILE FORMATS 
TABLE A.1 Lorenz Data (File No. 98) Format ${ }^{\text {a }}$

\begin{tabular}{|c|c|}
\hline Column & Content of Columns \\
\hline $1-3$ & Project number $(031)$ \\
\hline 4-6 & Experiment number ( 001 or may be blank) \\
\hline $7-9$ & Replication number (may be blank) \\
\hline $10-11$ & Strain code: $\mathrm{LAF}_{1}(01) ; \mathrm{C} 3 \mathrm{Hf}(05)$ \\
\hline 12 & Sex: male (1), female (2), castrate female (4) \\
\hline $13-17$ & Animal number \\
\hline $18-21$ & Cage number \\
\hline $22-27$ & $\begin{array}{l}\text { Dose (roentgens in air from } \mathrm{Ra}^{226} \text { point source) } \\
\text { Note that there are two decimal places }\end{array}$ \\
\hline $\begin{array}{l}28-32 \\
33-37 \\
38-42\end{array}$ & $\begin{array}{l}\text { Birth } \\
\text { Entry } \\
\text { Death }\end{array}\left\{\begin{array}{l}\text { Calendar dates } \\
\text { month }(00) \text {, day }(00), \text { year }(0) \\
\text { e.g., Dec. } 7,1946=12076\end{array}\right.$ \\
\hline 43 & $\begin{array}{l}\text { Mode of death (exit code): dead (1), sacrificed or moribund ( } 2 \text { ), } \\
\text { missing (3), accidental death (4), discard (5) }\end{array}$ \\
\hline $44-47$ & Age at death $(\mathrm{d})$ \\
\hline $48-51$ & Age at entry and start of irradiation (d) \\
\hline $52-55$ & Survival time, from start of irradiation (d) \\
\hline $\begin{array}{l}56-60 \\
61-65\end{array}$ & Parents (not otherwise specified in available notes) \\
\hline $66-73$ & Survival time squared: $(\text { Col. } 52-55)^{2}=$ Col. $66-73$ \\
\hline
\end{tabular}

a Survival data from the studies performed at the National Cancer Institute by Egon Lorenz in the period 1943 to 1953. 
TABLE A.2 XAM-3 Data (File No. 96) Format ${ }^{\mathrm{a}}$

\begin{tabular}{ll}
\hline Column & \multicolumn{1}{c}{ Content of Columns } \\
\hline $1-3$ & Project number (006) \\
$4-6$ & Experiment number (002) \\
$7-9$ & Replication number (blank for controls) \\
$10-11$ & Strain code \\
12 & Sex \\
$13-17$ & Animal number \\
$18-21$ & Cage number \\
$22-27$ & Dose (R) \\
$28-31$ & Mating number \\
$32-33$ & Parity \\
$34-35$ & Number born (for given mating and parity) \\
$36-37$ & Number weaned (for given mating and parity) \\
$38-40$ & Age of dam (d) \\
$41-44$ & Age at entry and age at exposure (d) \\
45 & Mode of death (exit code) \\
$46-49$ & Survival time (d) from exposure \\
50 & Autopsy code \\
$51-54$ & Age at exit (d) \\
\hline $65-62$ & Pathology codes (4 pairs of 2-digit codes) \\
\hline 65 & Body weight at entry (g) \\
\hline 6 & Coat color \\
\hline 6
\end{tabular}

a Acute and chronic response of young adult inbred, hybrid, and mutant stocks of mice to single doses of 200-kVp x-rays. 
TABLE A.3 GCM-4 Data (File No. 87) Format ${ }^{\text {a }}$

\begin{tabular}{|c|c|}
\hline Column & Content of Columns \\
\hline $1-3$ & Project number $(010)$ \\
\hline 4-6 & Experiment number (001) \\
\hline $7-9$ & Replication number \\
\hline $10-11$ & Strain Code $\mathrm{LAF}_{1}(01)$ \\
\hline 12 & Sex \\
\hline $13-17$ & Animal number \\
\hline $18-21$ & Cage number \\
\hline $22-27$ & Dose $(\mathrm{R} / \mathrm{d})$ \\
\hline \multirow[t]{2}{*}{$28-31$} & $\begin{array}{l}\text { Cage position (location in the radiation field) } \\
\begin{aligned} 28-29 & =\text { Rack number } \\
30 & =\text { Shelf number } \\
31 & =\text { Position on shelf }\end{aligned}\end{array}$ \\
\hline & 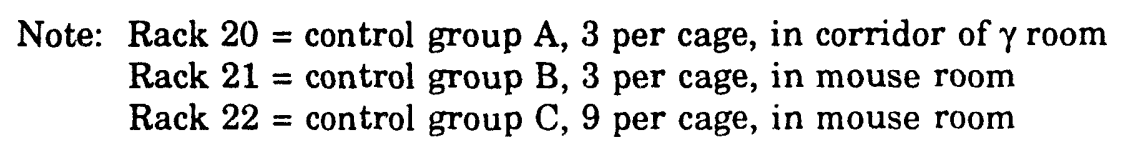 \\
\hline $\begin{array}{l}32-34 \\
35-37 \\
38-40\end{array}$ & $\begin{array}{l}\text { Body weights (g) preceding entry and on day of entry into } \gamma \text {-ray } \\
\text { room, taken at } 2 \text {-week intervals }\end{array}$ \\
\hline 41-44 & Age at entry and start of irradiation (d); all 0100 in this experiment \\
\hline 45 & Mode of death (exit code) \\
\hline $46-49$ & Survival time, from start of irradiation (d) \\
\hline 50 & Autopsy code \\
\hline $51-54$ & Blank \\
\hline $55-64$ & $\begin{array}{l}\text { Pathology codes (five pairs of two-digit codes; no pathologic findings } \\
\text { at doses } \geq 64 \mathrm{R} / \mathrm{d} \text { ) }\end{array}$ \\
\hline
\end{tabular}

a Acute and chronic response of young adult $\mathrm{LAF}_{1}$ mice to daily duration-of-life ${ }^{60} \mathrm{Co} \gamma$ irradiation. 
TABLE A.4 GCM-8 Data (File No. 59) Format

\begin{tabular}{|c|c|}
\hline Column & Content of Columns \\
\hline $1-3$ & Project number (001) and (010) for strain 07 from GCM-12 \\
\hline 4-6 & Experiment number (011) and (014) for strain 07 from GCM-12 \\
\hline $7-9$ & Replication number \\
\hline $10-11$ & Strain code \\
\hline 12 & Sex \\
\hline $13-17$ & Animal number \\
\hline $18-21$ & Cage number \\
\hline 22 & Subcage number $1,2,3$, and 4 (if no subcage, $=0$ ) \\
\hline $23-28$ & Dose $(\mathrm{R} / \mathrm{d})$ \\
\hline 29-33 & $\begin{array}{l}\text { Cage Position (location in the radiation field) } \\
\begin{aligned} 29-30 & =\text { Rack number } \\
31 & =\text { Shelf number } \\
32-33 & =\text { Position on shelf }\end{aligned}\end{array}$ \\
\hline $\begin{array}{l}34-36 \\
37-39 \\
40-42\end{array}$ & $\begin{array}{l}\text { Body weights (g) preceding entry and on day of entry into } \gamma \text {-ray } \\
\text { room, taken at } 2 \text {-wk intervals }\end{array}$ \\
\hline $43-46$ & Age at entry and start of irradiation (d) \\
\hline 47 & Mode of death (exit code) \\
\hline $48-51$ & Survival time, from start of irradiation (d) \\
\hline 52 & Autopsy code \\
\hline $53-56$ & Age at exit (d) \\
\hline $57-64$ & Pathology codes (four pairs of two-digit codes) \\
\hline $66-68$ & Mating number \\
\hline $69-70$ & Parity of litter within mating number for mouse involved \\
\hline
\end{tabular}


TABLE A.4 (Cont.)

Column Contents of Colums

71 Coat color (blank if an inbred or non-segregating generation)

72-75 Paired cage (most entries involved a pair, 1 male and 1 female cage, three per cage)

76-79 Blank

80 Code 1 = Pool F1's (strains 08 and 09)

Code 2 = Pool F2's (strains 12 and 13)

a Acute and chronic response of young adult inbred and hybrid mice to daily duration-of-life ${ }^{60} \mathrm{Co} \gamma$ irradiation. 
TABLE A.5 GCM-12 Data (File Nos. 66 and 27)

Format $^{\mathrm{a}}$

\begin{tabular}{|c|c|}
\hline Column & Content of Columns \\
\hline $1-3$ & Project number (010) \\
\hline $4-6$ & Experiment number (014) \\
\hline $7-9$ & Replication number \\
\hline $10-11$ & Strain code \\
\hline 12 & Sex \\
\hline $13-17$ & Animal number \\
\hline $18-22$ & $\begin{aligned} 18-21= & \text { cage number } \\
22= & \text { subcage number } 1,2,3, \text { and } 4 \\
& (\text { if no subcage },=0)\end{aligned}$ \\
\hline $23-28$ & Dose (R/d); one decimal place (col. 28) \\
\hline $29-34$ & $\begin{array}{l}\text { Cage position (location in the radiation field) } \\
29-30=\text { Rack number } \\
31-32=\text { Shelf number } \\
33-34=\text { Position on shelf } \\
\text { (If a room number, all zeroes) }\end{array}$ \\
\hline $35-38$ & Mating number \\
\hline $39-40$ & Parity of litter within mating number \\
\hline $41-44$ & Age at entry and start of irradiation (d) \\
\hline 45 & Mode of death (exit code) \\
\hline $46-49$ & Survival time, from start of irradiation (d) \\
\hline 50 & Autopsy code \\
\hline $51-54$ & Age at exit (d) \\
\hline $55-70$ & Pathology codes (eight pairs of two-digit codes) \\
\hline $71-73$ & Body weight at entry (g); to one decimal place \\
\hline
\end{tabular}

a Acute and chronic response of young adult inbred and hybrid mice to daily duration-of-life ${ }^{60} \mathrm{Co} \gamma$ irradiation. 
TABLE A.6 GCM-9A Data (File No. 75) Format ${ }^{\text {a }}$

\begin{tabular}{|c|c|}
\hline Column & Content of Columns \\
\hline $1-3$ & Project number $(010)$ \\
\hline $4-6$ & Experiment number $(002)$ \\
\hline $7-9$ & Replication number \\
\hline $10-11$ & Strain code $(01)$ \\
\hline 12 & Sex \\
\hline $13-17$ & Animal number \\
\hline $18-21$ & Cage number \\
\hline $22-27$ & Dose $(R / d)$; all zeroes for these pre-irradiation data \\
\hline $28-31$ & Cage position; all zeroes for these pre-irradiation data \\
\hline $\begin{array}{l}32-34 \\
35-37 \\
38-40\end{array}$ & Body weights (g) preceding entry $\left\{\begin{array}{c}-4 \text { weeks } \\
-2 \text { weeks } \\
0 \text { weeks, day of entry }\end{array}\right.$ \\
\hline $41-44$ & Age at entry (d); all 0100 in this experiment \\
\hline 45 & Mode of death (exit code) \\
\hline $46-49$ & Survival time or time from entry (d) \\
\hline 50 & Autopsy code \\
\hline $51-52$ & Future replication in an irradiation series (may be blank or zeroes) \\
\hline $53-54$ & Future experiment (incomplete information) \\
\hline
\end{tabular}

${ }^{a}$ Dependence of response to daily duration-of-life ${ }^{60} \mathrm{Co} \gamma$ irradiation upon age at first exposure; pre-irradiation data for $\mathrm{LAF}_{1}$ mice. 
TABLE A.7 GCM-9B Data (File No. 75) Format ${ }^{\text {a }}$

\begin{tabular}{|c|c|}
\hline Column & Content of Columns \\
\hline $1-3$ & Project number $(010)$ \\
\hline $4-6$ & Experiment number (002) \\
\hline $7-9$ & Replication number \\
\hline $10-11$ & Strain code \\
\hline 12 & Sex \\
\hline $13-17$ & Animal number \\
\hline $18-21$ & Cage number \\
\hline $22-27$ & Dose $(\mathrm{R} / \mathrm{d})$ \\
\hline $28-31$ & $\begin{array}{l}\text { Cage position (location in the radiation field) } \\
\begin{aligned} 28-29 & =\text { Rack number } \\
30 & =\text { Shelf number } \\
31 & =\text { Position on shelf }\end{aligned}\end{array}$ \\
\hline $32-34$ & Body weight $(\mathrm{g})$ at entry into $\gamma$-ray room \\
\hline $35-38$ & Previous cage number \\
\hline $39-40$ & Blank \\
\hline $41-44$ & Age at entry and start of irradiation (d) \\
\hline 45 & Mode of death (exit code) \\
\hline $46-49$ & Survival time, from start of irradiation (d) \\
\hline 50 & Autopsy code \\
\hline $51-54$ & Age at exit (d) \\
\hline
\end{tabular}

a Dependence of response to daily duration-of-life ${ }^{60} \mathrm{Co}$ $\gamma$ irradiation upon age at first exposure for inbred and hybrid mice. 
TABLE A.8 GAM/GFM Data (File No. 73 [GAM-2] and File No. 82 [GFM-1] combined) Format ${ }^{\mathrm{a}}$

\begin{tabular}{|c|c|}
\hline Column & Content of Columns \\
\hline $1-3$ & Project number (010) \\
\hline 4-6 & Experiment number (005 and 004) \\
\hline $7-9$ & Replication number \\
\hline $10-11$ & Strain code (01) \\
\hline 12 & Sex \\
\hline $13-17$ & Animal number \\
\hline $18-21$ & Cage number \\
\hline $22-23$ & $\begin{array}{l}\text { Interval between split dose: } 450 \text { and } 750 \text { were split in half and delivered } \\
\text { with one of } 9 \text { intervals between halves. Interval code: } 0(00), 0.125 \mathrm{~d} \\
(02), 0.4 \mathrm{~d}(03), 1 \mathrm{~d}(04), 3 \mathrm{~d}(05), 5 \mathrm{~d}(06), 7 \mathrm{~d}(07), 14 \mathrm{~d}(08), 28 \mathrm{~d}(09) \text {. }\end{array}$ \\
\hline $24-27$ & Dose, ${ }^{60}$ Co $\gamma$-rays (R) \\
\hline $28-31$ & Cage position (all zeroes in these experiments) \\
\hline $\begin{array}{l}32-34 \\
35-37 \\
38-40\end{array}$ & Body weights (g) preceding entry $\left\{\begin{array}{l}-4 \text { weeks } \\
-2 \text { weeks } \\
0 \text { weeks, day of entry }\end{array}\right.$ \\
\hline $41-44$ & Age at entry (d); all entries are 0100 \\
\hline 45 & Exit code \\
\hline $46-49$ & Survival time from irradiation (d) \\
\hline 50 & Autopsy code \\
\hline $51-54$ & Age at exit (d) \\
\hline $55-64$ & Pathology codes (five pairs of two-digit codes) \\
\hline 65 & Start time: $1=$ day $0,2=$ day $14,3=$ day 28 \\
\hline
\end{tabular}

a Acute and chronic response of young adult $\mathrm{LAF}_{1}$ mice to single and split doses of ${ }^{60} \mathrm{Co} \gamma$ irradiation. 
TABLE A.9 XAM-6 Data (File No. 67) Format ${ }^{a}$

\begin{tabular}{ll}
\hline Column & \multicolumn{1}{c}{ Content of Columns } \\
\hline $1-3$ & Project number (006) \\
$4-6$ & Experiment number (004) \\
$7-9$ & Replication number \\
$10-11$ & Strain code \\
12 & Sex \\
$13-17$ & Animal number \\
$18-22$ & Cage and subcage number \\
$23-28$ & Dose (R); one decimal place \\
$29-34$ & Cage position (all zeroes in this experiment) \\
$35-38$ & Mating number \\
$39-40$ & Parity \\
$41-44$ & Age at entry and exposure (d) \\
45 & Exit code \\
$46-49$ & Survival time from exposure (d) \\
50 & Autopsy code \\
$51-54$ & Age at exit (d) \\
$55-62$ & Pathology codes (four pairs of two-digit codes) \\
\hline $72-74$ & Body weight at entry (g); one decimal place \\
\hline
\end{tabular}

a Chronic effects of sublethal single doses of $200-\mathrm{kVp}$ $\mathrm{x}$-rays on young adult inbred and hybrid mice. 
TABLE A.10 XAM-7 Data (File No. 69) Format ${ }^{\text {a }}$

\begin{tabular}{ll}
\hline Column & \multicolumn{1}{c}{ Content of Columns } \\
\hline $1-3$ & Project number (006) \\
$4-6$ & Experiment number (005) \\
$7-9$ & Replication number \\
$10-11$ & Strain code \\
12 & Sex \\
$13-17$ & Animal number \\
$18-22$ & Cage and subcage number \\
$23-28$ & Dose, (R); one decimal place \\
$29-34$ & Cage position (all zeroes in this experiment) \\
$35-38$ & Mating number \\
$39-40$ & Parity \\
$41-44$ & Age at entry and exposure (d) \\
45 & Exit code \\
$46-49$ & Survival time from exposure (d) \\
50 & Autopsy code \\
$51-54$ & Age at exit (d) \\
\hline $55-62$ & Pathology codes (four pairs of two-digit codes) \\
\hline
\end{tabular}

a Influence of age on the chronic effects of sublethal single doses of $200-k V p$ x-rays on inbred and hybrid mice. 
TABLE A.11 Pre-Experimental Stock Cage Record

(File No. 94) Format ${ }^{\mathrm{a}}$

\begin{tabular}{|c|c|}
\hline Column & Content of Columns \\
\hline $1-3$ & Project number $(000)$ \\
\hline $4-9$ & Blank \\
\hline $10-11$ & Strain code \\
\hline 12 & Sex \\
\hline $13-17$ & Animal number \\
\hline $18-21$ & Cage number \\
\hline 22 & Blank \\
\hline $23-28$ & Birth date: $23-24$, month; 25-26, day; $27-28$, year \\
\hline 29-34 & Exit date: $29-30$, month; $31-32$, day; $33-34$, year \\
\hline $35-38$ & Mating number \\
\hline $39-40$ & Parity \\
\hline $41-44$ & Blank \\
\hline 45 & Exit code \\
\hline $46-49$ & Blank \\
\hline 50 & Autopsy code \\
\hline $51-54$ & Survival time (d); (Col. 29-34 minus Col. 23-28) \\
\hline $55-62$ & Pathology codes (four pairs of two-digit codes) \\
\hline $63-65$ & Future projects \\
\hline $66-68$ & Future experiments \\
\hline $69-71$ & Future replication \\
\hline
\end{tabular}

a Survival record from weaning to experimental use or discard for six inbred and one hybrid mouse stocks during the period 1958-1969. 
TABLE A.12 Mating Record (File No. 88) Format

\begin{tabular}{|c|c|}
\hline Column & Content of Columns \\
\hline $1-3$ & Project number (011) \\
\hline $4-5$ & Strain \\
\hline 6 & Blank \\
\hline $7-9$ & Generation \\
\hline $10-12$ & Dam strain \\
\hline $13-17$ & Dam animal number \\
\hline $18-20$ & Sire strain \\
\hline 21-25 & Sire animal number \\
\hline $26-29$ & Mating number \\
\hline $30-35$ & Dam birth date: $30-31$, month; $32-33$, day; $34-35$, year \\
\hline $36-41$ & Date mated: $36-37$, month; $38-39$, day; $40-41$, year \\
\hline $42-47$ & Date discarded: $42-43$, month; $44-45$, day; $46-47$, year \\
\hline 48 & $\begin{aligned} & \text { Reason for discard: } \\
& 1 \text { Dam dead } \\
& 2 \text { Sire dead } \\
& 3 \text { Retired (discarded) } \\
& 4 \text { Dam discard (sacrifice) }\end{aligned}$ \\
\hline
\end{tabular}


TABLE A.13 Litter Record (File No. 95) Format ${ }^{\text {a }}$

\begin{tabular}{|c|c|c|}
\hline Column & & Content of Columns \\
\hline $1-3$ & \multicolumn{2}{|c|}{ Project number (011) } \\
\hline 4-5 & \multicolumn{2}{|l|}{ Strain } \\
\hline $6-9$ & \multicolumn{2}{|c|}{ Page number (page number in the strain pedigree book) } \\
\hline $\begin{array}{l}10-12 \\
13-17\end{array}$ & \multicolumn{2}{|c|}{$\left.\begin{array}{l}\text { Generation number } \\
\text { Animal number }\end{array}\right\}$ Dam } \\
\hline $\begin{array}{l}18-20 \\
21-25\end{array}$ & \multicolumn{2}{|c|}{$\left.\begin{array}{l}\text { Generation number } \\
\text { Animal number }\end{array}\right\}$ Sire } \\
\hline 26-29 & \multicolumn{2}{|l|}{ Mating number } \\
\hline $30-31$ & \multicolumn{2}{|l|}{ Parity } \\
\hline $32-36$ & Birth date: & $32-33$, month; $34-35$, day; 36, year \\
\hline $37-41$ & Date weaned: & $37-38$, month; $39-40$, day; 41 , year \\
\hline $42-49$ & Number born: & $\begin{array}{l}\text { 42-43, number born; } 44-45 \text {, male; } \\
46-47 \text {, female; } 48-49 \text {, unknown }\end{array}$ \\
\hline $50-55$ & Number weaned: & $\begin{array}{l}50-51, \text { male; } 52-53, \text { female; } \\
54-55, \text { total weaned }\end{array}$ \\
\hline \multirow[t]{3}{*}{$56-73$} & \multicolumn{2}{|c|}{ Number dead (by following age intervals): } \\
\hline & 6-15 d: & 62-63 (M), 64-65 (F), 66-67 (unknown) \\
\hline & 16 d-weaning: & 68-69 (M), 70-71 (F), 72-73 (unknown) \\
\hline 74-76 & \multicolumn{2}{|c|}{ Age (d) of dam (at birth of given parity) } \\
\hline
\end{tabular}

a Record of all matings with at least one litter born for all strains, hybrids, and mutant stocks during the period 1953-1969. 
TABLE A.14 Combined Mating and Litter Records 1953-1969 (File Nos. 88 and 95) Format

\begin{tabular}{|c|c|c|}
\hline Column & \multicolumn{2}{|r|}{ Content of Columns } \\
\hline $1-3$ & \multicolumn{2}{|c|}{ Project number $(011)$} \\
\hline $4-5$ & \multicolumn{2}{|c|}{ Strain of litter (see code list in Appendix B) } \\
\hline $6-9$ & \multicolumn{2}{|c|}{ Page number in the strain pedigree book } \\
\hline $10-12$ & \multicolumn{2}{|c|}{ Generation number (from Mating Record) } \\
\hline $\begin{array}{l}13-15 \\
16-20\end{array}$ & \multicolumn{2}{|c|}{$\left.\begin{array}{l}\text { Strain code (from Mating Record) } \\
\text { Animal number }\end{array}\right\}$ Dam } \\
\hline $\begin{array}{l}21-23 \\
24-28\end{array}$ & \multicolumn{2}{|c|}{$\left.\begin{array}{l}\text { Strain code (from Mating Record) } \\
\text { Animal number }\end{array}\right\}$ Sire } \\
\hline 29-32 & \multicolumn{2}{|l|}{ Mating number } \\
\hline $33-34$ & \multicolumn{2}{|l|}{ Parity } \\
\hline $35-40$ & Birth date: & $35-36$, month; $37-38$, day; $39-40$, year \\
\hline $41-46$ & Date weaned: & $41-42$, month; 43-44, day; $45-46$, year \\
\hline 47-54 & Number born: & $\begin{array}{l}\text { 47-48 (number born), 49-50 (male) } 51-52 \text { (female), } \\
53-54 \text { (unknown) }\end{array}$ \\
\hline $55-60$ & Number weaned: $55-56$, male; $57-58$, female; $59-60$, total weaned & $55-56$, male; $57-58$, female; $59-60$, total weaned \\
\hline $61-78$ & \multicolumn{2}{|c|}{ 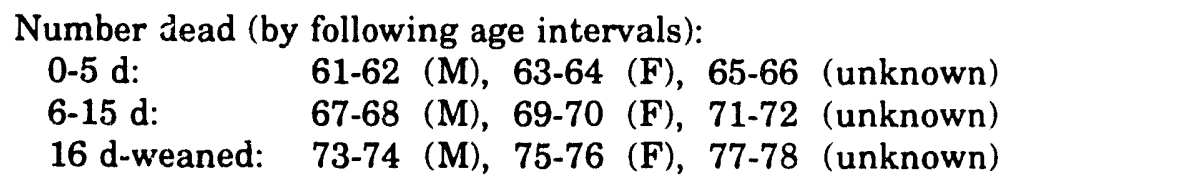 } \\
\hline $79-81$ & \multicolumn{2}{|c|}{ Age (d) of dam (at birth of given parity) } \\
\hline $82-87$ & \multicolumn{2}{|c|}{ Dam birth date (from Mating Record: month, day, year) } \\
\hline $88-93$ & \multicolumn{2}{|c|}{ Date mated (from Mating Record: month, day, year) } \\
\hline $94-99$ & \multicolumn{2}{|c|}{ Date discarded (from Mating Record: month, day, year) } \\
\hline 100 & $\begin{array}{ll}\text { Reason for discar } \\
1 & \text { Dam dead } \\
2 & \text { Sire dead } \\
3 & \text { Retired (disc } \\
4 & \text { Dam discard }\end{array}$ & $\begin{array}{l}5 \text { Sire discard (sacrifice) } \\
6 \text { To a new mating } \\
7 \text { Sire to age dependency }\end{array}$ \\
\hline
\end{tabular}


APPENDIX B:

STRAIN CODES, STRAIN DESIGNATIONS, AND BRIEF NOTES ON CHARACTERISTICS 


\section{STRAINS}

\begin{tabular}{|c|c|c|}
\hline Code & Designation & Brief Characteristics and Other Comments \\
\hline 01 & $\mathrm{LAF}_{1}$ & Purchased from Jackson Labs, 1954-1957 (C57L $\times \mathrm{A} / \mathrm{J}) \mathrm{F}_{1}$ \\
\hline 02 & $\mathrm{~A} / \mathrm{He}$ & From W.E. Heston, NCl, May 1953, at $\mathrm{F}_{90,92}$ \\
\hline 03 & $\mathrm{~A} / \mathrm{J}$ & From Jackson Labs, April 1953 , at $F_{85,86,87}$ \\
\hline 04 & $\mathrm{BALB} / \mathrm{cJ}$ & From Jackson Labs, April 1953, at $F_{53,55,56}$ \\
\hline 05 & $\mathrm{C} 3 \mathrm{Hf} / \mathrm{He}$ & $\begin{array}{l}\text { From W.E. Heston, NCI, March } 1953 \text {, at } \mathrm{F}_{20} \text { from time of foster } \\
\text { nursing to eliminate mammary tumor virus }\end{array}$ \\
\hline 06 & C57BL/6J & From Jackson Labs, April 1953, at $\mathrm{F}_{37,39}$ \\
\hline 07 & C57L & From W.E. Heston, NCI, June 1954 , at $\mathrm{F}_{58,59}$ \\
\hline 08 & $\mathrm{~B} \mathrm{CF}_{1}$ & $\mathrm{C} 57 \mathrm{BL} / 6$ \% $\times \mathrm{BALB} / \mathrm{c}$ or $\mathrm{F}_{1}$ \} \\
\hline 09 & $\mathrm{CB}_{6} \mathrm{~F}_{1}$ & $\left.\mathrm{BALB} / \mathrm{c}+\mathrm{C} 57 \mathrm{BL} / 6 \mathrm{~F}_{1}\right\}$ Combined into single Code 08 \\
\hline 10 & $\mathrm{BCA}$ & $\mathrm{B} 6 \mathrm{CF}_{1} \times \mathrm{A} / \mathrm{J}$ \\
\hline 11 & CBA & $\left.\mathrm{CB}_{6 \mathrm{~F}_{1}} \times \mathrm{A} / \mathrm{J}\right\}$ Limitea tests/proauct \\
\hline 12 & $\mathrm{CB}_{6} \mathrm{~F}_{2}$ & $\mathrm{CB}_{6} \mathrm{~F}_{1} \times \mathrm{CB} \mathrm{F}_{1}$ \\
\hline 13 & $\mathrm{~B}_{6} \mathrm{CF}_{2}$ & $\left.\mathrm{~B} \mathrm{CF}_{1} \times \mathrm{B}^{2} \mathrm{CF}_{1}\right\}$ Combined into single Code 12 \\
\hline 14 & $\mathrm{CB} / \mathrm{BC} \mathrm{F} \mathrm{F}_{3}$ & From matings of $F_{2}$ mice, Codes 12 and 13 \\
\hline 15 & $\mathrm{BC}_{\mathrm{I}}$ & $\begin{array}{l}\text { Progeny of first backcross of the } \mathrm{B} 6 \mathrm{CF}_{1} \text { mated to } \mathrm{BALB} / \mathrm{c} \\
\left.\text { (the } \mathrm{P}_{1}\right) \text {, using reciprocal matings }\left(\mathrm{F}_{1}+\times \mathrm{P}_{1} \sigma^{*} \text { and }\right. \\
\left.\mathrm{P}_{1} \% \times \mathrm{F}_{1} \sigma^{*}\right)\end{array}$ \\
\hline 16 & $\mathrm{BC}_{\mathrm{II}}$, albino & $\begin{array}{l}\text { Progeny of second backcross to } \mathrm{BALB} / \mathrm{c}\left(\mathrm{BC}_{\mathrm{I}} \times \mathrm{BALB} / \mathrm{c}\right) \text {, using } \\
\text { the albino } \mathrm{BC}_{\mathrm{I}} \text { parent and reciprocal matings }\end{array}$ \\
\hline 17 & $\mathrm{BC}_{\mathrm{II}}$, brown agouti & $\begin{array}{l}\text { Progeny of second backcross to } \mathrm{BALB} / \mathrm{c} \text {, using brown agouti } \\
\mathrm{BC}_{\mathrm{I}} \text { parent and reciprocal matings }\end{array}$ \\
\hline 18 & $\mathrm{BC}_{2}$ & $\begin{array}{l}\text { Progeny of first backcross of the } \mathrm{B}^{2} \mathrm{CF}_{1} \text { mated to } \mathrm{C} 57 \mathrm{BL} / 6 \\
\text { (the } \mathrm{P}_{2} \text { ); reciprocal matings }\end{array}$ \\
\hline 19 & $\mathrm{BC}_{\mathrm{III}}$, albino & $\begin{array}{l}\text { Third backcross to } \mathrm{BALB} / \mathrm{c}\left(\mathrm{BC}_{\mathrm{II}} \times \mathrm{BAL} \mathrm{B} / \mathrm{c}\right) \text {, using the albino } \\
\mathrm{BC}_{\mathrm{II}} \text { parent and reciprocal matings }\end{array}$ \\
\hline 20 & $\mathrm{BC}_{\mathrm{III}}$, brown agouti & $\begin{array}{l}\text { Third backcross to } \mathrm{BALB} / \mathrm{c} \text {, using the brown agouti } \mathrm{BC}_{\mathrm{II}} \text { parent } \\
\text { and reciprocal matings }\end{array}$ \\
\hline 21 & C57BL/6-G & $\begin{array}{l}\text { Progeny from irradiated C57BL/6 parents - limited tests and } \\
\text { little data in file }\end{array}$ \\
\hline 22 & $\mathrm{BC}_{\mathrm{IV}}$, albino & $\begin{array}{l}\text { Fourth backcross to } \mathrm{BALB} / \mathrm{c}\left(\mathrm{BC}_{\mathrm{III}} \times \mathrm{BALB} / \mathrm{c}\right) \text {, using the albino } \\
\mathrm{BC}_{\mathrm{III}} \text { parent and reciprocal matings }\end{array}$ \\
\hline 23 & $\mathrm{BC}_{\mathrm{IV}}$, brown agouti & $\begin{array}{l}\text { Fourth backcross to } \mathrm{BALB} / \mathrm{c} \text {, using the brown agouti } \mathrm{BC}_{\mathrm{III}} \\
\text { parent and reciprocal matings }\end{array}$ \\
\hline 24 & $\mathrm{BC}_{\mathrm{v}}$, albino & $\begin{array}{l}\text { Fifth backcross to } \mathrm{BALB} / \mathrm{c}\left(\mathrm{BC}_{\mathrm{IV}} \times \mathrm{BALB} / 2\right) \text {, using the albino } \\
\mathrm{BC}_{\mathrm{IV}} \text { parent and reciprocal matings }\end{array}$ \\
\hline 25 & $\mathrm{BC}_{\mathrm{V}}$, brown agouti & $\begin{array}{l}\text { Fifth backcross to } \mathrm{BALB} / \mathrm{c} \text {, using the brown agouti } \mathrm{BC}_{\mathrm{IV}} \text { parent } \\
\text { and reciprocal matings }\end{array}$ \\
\hline 26 & $\mathrm{BC}_{\mathrm{VI}}$, albino & $\begin{array}{l}\text { Sixth backcross }\left(\mathrm{BC}_{\mathrm{V}} \times \mathrm{BALB} / \mathrm{c}\right) \text {, albino } \mathrm{BC}_{\mathrm{V}} \text { parent, reciprocal } \\
\text { matings }\end{array}$ \\
\hline 27 & $\mathrm{BC}_{\mathrm{VI}}$, brown agouti & Sixth backcross, brown agouti $\mathrm{BC}_{\mathrm{V}}$ parent, reciprocal matings \\
\hline
\end{tabular}




\begin{tabular}{|c|c|c|}
\hline Code & Designation & Brief Characteristics and Other Comments \\
\hline 28 & $\mathrm{BALB} / \mathrm{c}-\mathrm{N} \mathrm{F}_{1}$ & $\begin{array}{l}\text { First inbred generation following seven outcross/backcross } \\
\text { generations; both parents } \mathrm{BC}_{\mathrm{VI}} \text { brown agouti }\end{array}$ \\
\hline 29 & $\mathrm{BALB} / \mathrm{c}-\mathrm{N} 7 \mathrm{~F}_{1}$ & $\begin{array}{l}\text { Brown agouti } \times \text { albino; } \mathrm{BC}_{\mathrm{VI}} \text { brown agouti } \times \mathrm{BC}_{\mathrm{VI}} \text { albino, } \\
\text { reciprocal matings }\end{array}$ \\
\hline 30 & $\mathrm{BALB} / \mathrm{c}-\mathrm{N} 7 \mathrm{~F}_{1}$ & Both parents albino, $\mathrm{BC}_{\mathrm{VI}}$ albino \\
\hline 31 & $\mathrm{BALB} / \mathrm{c}-\mathrm{N} 7 \mathrm{~F}_{2}$ & Second inbred generation; brown agouti parents \\
\hline 32 & $\mathrm{BALB} / \mathrm{c}-\mathrm{N} 7 \mathrm{~F}_{2}$ & Brown agouti $\times$ albino, reciprocal matings \\
\hline 33 & $\mathrm{BALB} / \mathrm{c}-\mathrm{N} 7 \mathrm{~F}_{2}$ & Albino parents \\
\hline 34 & $\begin{array}{l}\mathrm{BC}_{1} \times \mathrm{B}^{2} \mathrm{CF}_{1} \\
\text { (albino) }\end{array}$ & $\begin{array}{l}\text { Progeny of the mating of the } \mathrm{B}_{6} \mathrm{CF}_{1} \text { with first backcross } \\
\text { progeny (code } 15 \text { ), using albino } \mathrm{BC}_{1} \text { and reciprocal matings }\end{array}$ \\
\hline 35 & $\begin{array}{l}\mathrm{BC}_{1} \times \mathrm{B}_{6} \mathrm{CF}_{1} \\
\text { (brown agouti) }\end{array}$ & $\begin{array}{l}\text { As for strain code } 34 \text {, using the brown agouti } \mathrm{BC}_{\mathrm{I}} \text { and } \\
\text { reciprocal matings }\end{array}$ \\
\hline 37 & $\begin{array}{l}\mathrm{BC}_{\mathrm{VII}} \text {, brown } \\
\text { agouti }\end{array}$ & $\begin{array}{l}\text { Progeny of the seventh backcross to the BALB/c inbred } \\
\left.\text { parent (BALB/c-N7F } F_{2} \text {-brown agouti }(31) \times B A L B / c\right) \\
\text { reciprocal matings }\end{array}$ \\
\hline 39 & $\begin{array}{l}\mathrm{BC}_{\mathrm{VIII}} \text {, brown } \\
\text { agouti }\end{array}$ & $\begin{array}{l}\text { Eighth backcross }\left(\mathrm{BC}_{\mathrm{VII}}-\text { brown agouti } \times \mathrm{BALB} / \mathrm{c}\right) \text {, } \\
\text { reciprocal matings }\end{array}$ \\
\hline 41 & $\mathrm{BC}_{\mathrm{DX}}$, brown agouti & $\begin{array}{l}\text { Ninth backcross }\left(\mathrm{BC}_{\mathrm{VIII}}-\text { brown agouti } \times \mathrm{BALB} / \mathrm{c}\right) \text {, } \\
\text { reciprocal matings }\end{array}$ \\
\hline 43 & $\mathrm{BC}_{\mathrm{X}}$, brown agouti & $\begin{array}{l}\text { Tenth backcross }\left(\mathrm{BC}_{\mathrm{IX}}-\text { brown agouti } \times \mathrm{BALB} / \mathrm{c}\right) \\
\text { reciprocal matings }\end{array}$ \\
\hline 44 & $\begin{array}{l}\text { BALB/c-N11, } \\
\text { brown agouti } \\
\text { (BALB/c-C(N11) }\end{array}$ & $\begin{array}{l}\text { BALB/c strain maintained by full-sib matings following eleven } \\
\text { outcross/backcross generations; parents selected for brown } \\
\text { agouti color (non-albino) }\end{array}$ \\
\hline 46 & $\mathrm{C} 57 \mathrm{BL} / 6-\mathrm{A}^{y}$ & $\begin{array}{l}\text { Dominant mutant "yellow" }\left(A^{y}\right) \text { from Jackson Lab in } 1963 \text {, } \\
\text { maintained on inbred C57BL/6 strain }\end{array}$ \\
\hline $\begin{array}{l}47-58 \\
61\end{array}$ & & $\begin{array}{l}\text { Inbred strains and genetic marker stocks obtained from } \\
\text { Prof. J.W. Gowen, Dept. of Genetics, Iowa State University, } \\
\text { in September } 1963 \text {. No generation number was available for } \\
\text { the inbred strains, so the stocks were started as if from "0" } \\
\text { generations of inbreeding with the first full-sib matings set } \\
\text { up at ANL, September } 23,1963 \text {. All of the strains were of } \\
\text { long standing, however, some dating back to the } 1920 \text { s. } \\
\text { Some brief remarks are given for each strain in the } \\
\text { continuation of this Appendix. }\end{array}$ \\
\hline
\end{tabular}




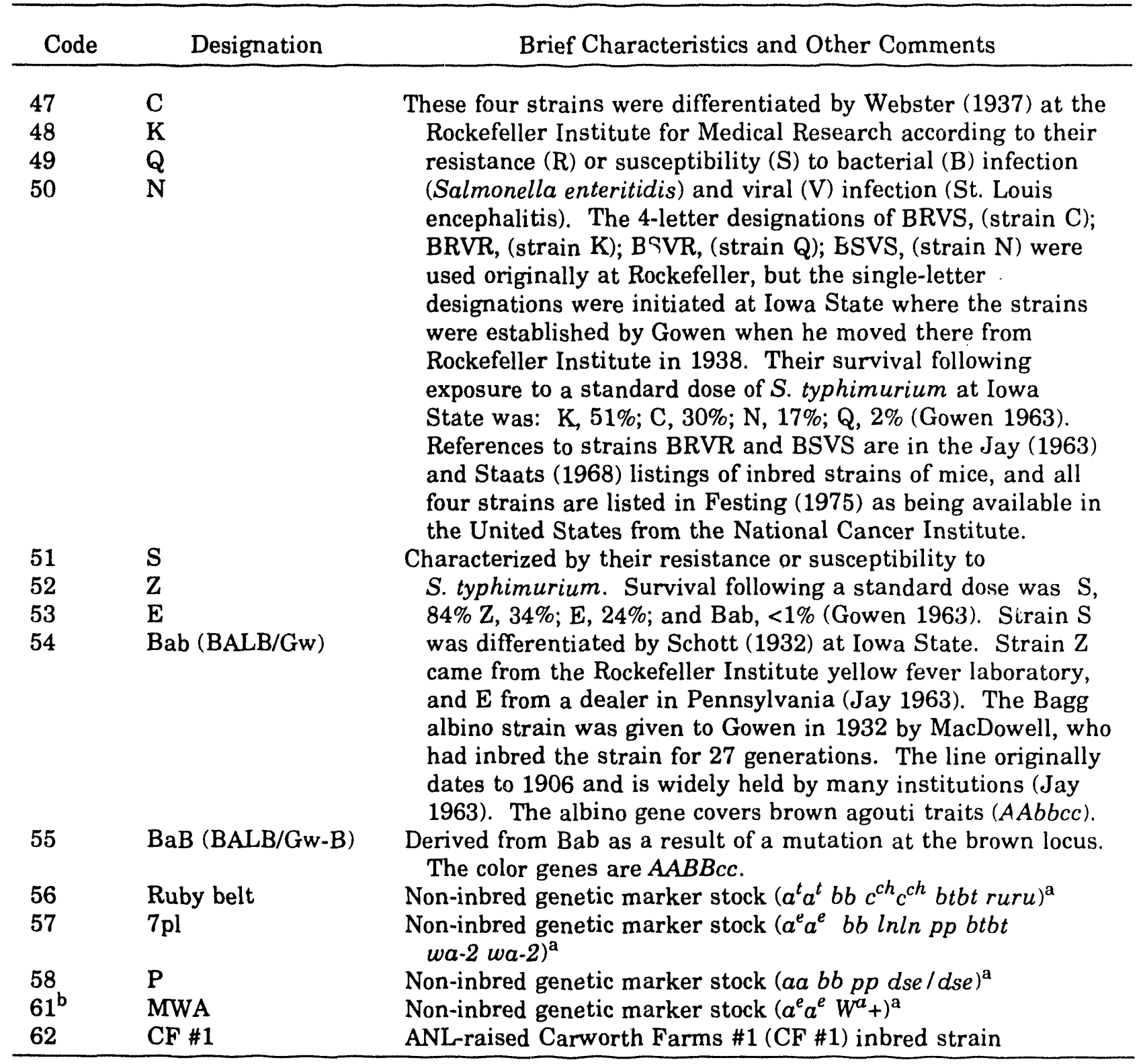

a Gene symbols: $A^{y}$ : yellow; $A$ : wild type agouti; $a^{t}$ : black $\&$ tan; $a$ : non-agouti; $a^{e}$ : extreme non-agouti; $B$ : wild type; $b$ : brown; $c^{c h}$ : chinchilla; $c$ : albino; bt: belted; $l n$ : leaden; $p$ : pinkeyed dilute; $r u$ : ruby-eye; $w a-2$ : waved hair; $W^{a}$ : Ames dominant white spotting; dse: dilute color, short-ear (closely linked genes).

b In the mating record, mice coded 61 derived from mice coded 59 and 60 , reciprocally mated. $59=a^{e} a^{e}++$ and $60=a^{e} a^{e} W^{a}+$. These were not specific strains but were segregants of 61 , since 61 was heterozygous at the $W^{a}$ locus. This use of strain codes 59 and 60 was a recordkeeping convenience, thus they are not listed in Appendix B. 


\section{APPENDIX C:}

\section{DATA CODES AND RADIATION PROTOCOLS}




\section{TABLE C.1 Pre-JANUS Data Codes}

Sex Codes

1 Male

2 Female

Mode of Exit Codes

1 Natural death

2 Sacrifice

3 Missing

4 Accidental

5 Discard

6 Sacrifice moribund

7 Breeder

8 (no pre-JANUS code)

9 Removal to another experiment

Autopsy Codes

0 No autopsy code recorded

1 Autopsy (tissues saved)

2 Autopsy (gross only)

3 No autopsy

Coat Color Codes

1 Albino $c c$

2 Black $B$

3 Brown $\overline{b b}$

4 Black agouti $A \_B$

5 Brown agouti $\bar{A} \_\bar{b} b$

6 Extreme non-agouti $a^{e} a^{e}$

7 Ames dominant white spotting $W^{a}$ 
TABLE C.2 Equivalence of Pre-JANUS and JANUS Codes

Autopsy Codes

Pre-JANUS

0 No autopsy code

1 Autopsy, tissue saved

2 Autopsy, gross only

3 No autopsy

\section{Exit Codes}

Pre-JANUS

1 Natural death

2 Sacrifice (programmed)

3 Missing

4 Accidental

5 Discard

6 Sacrifice moribund

7 Breeder

8 (no pre-JANUS code)

9 Removal to another experiment

\section{JANUS}

$=\quad$ No JANUS code

$=\mathrm{A}$ (autopsied) + MACRO and MICRO record

$=\mathrm{A}$ (autopsied) + MACRO record only

$=\mathrm{N}$ (not autopsied), $\mathrm{C}$ (cannibalized), and $\mathrm{D}$ (decomposed)

Experiment Numbers

Pre-JANUS

GFM-1

GAM-2

XAM-3

GCM-4

XAM-6

XAM-7

GCM-8

GCM-9B

GCM-12
JANUS

$=1$ Radiation death

$=4$ Programmed sacrifice

$=3$ Missing

$=3$ Accidental death

$=5$ Discard

$=2$ Sacrifice moribund

$=8$ Breeders

$=6$ Removal to another experiment

JANUS
$\mathbf{5 1}$
$\mathbf{5 2}$
$\mathbf{5 3}$
$\mathbf{5 4}$
$\mathbf{5 6}$
$\mathbf{5 7}$
$\mathbf{5 8}$
$\mathbf{5 9}$
$\mathbf{6 2}$



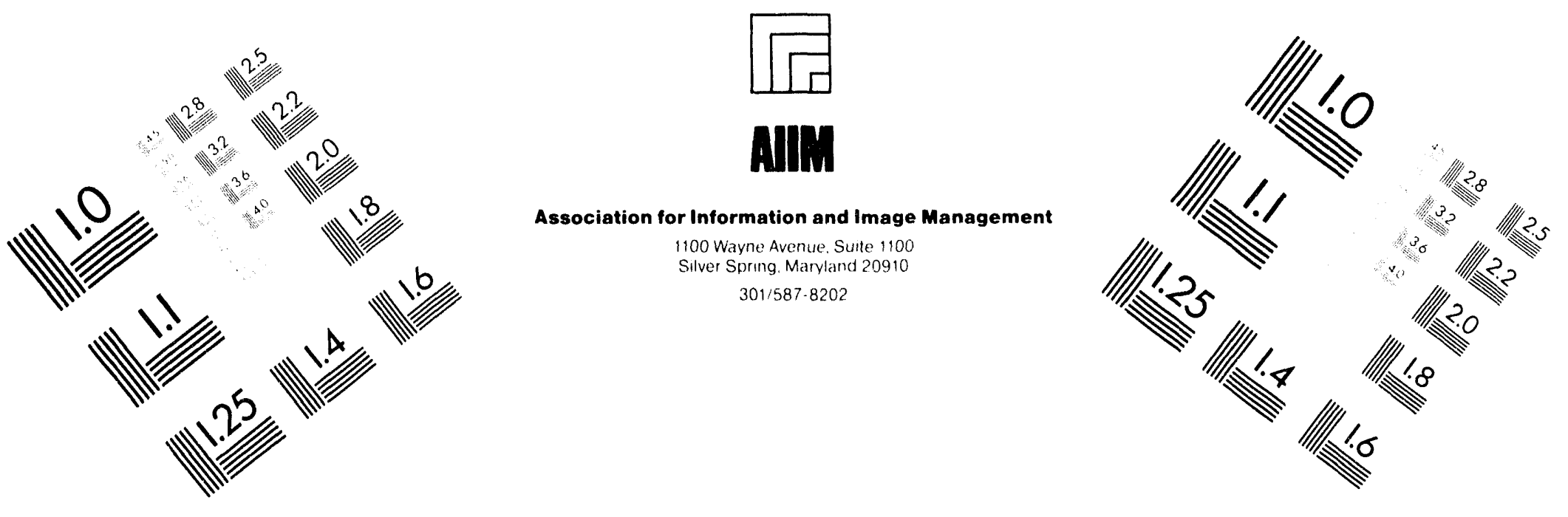

\section{Centimeter}

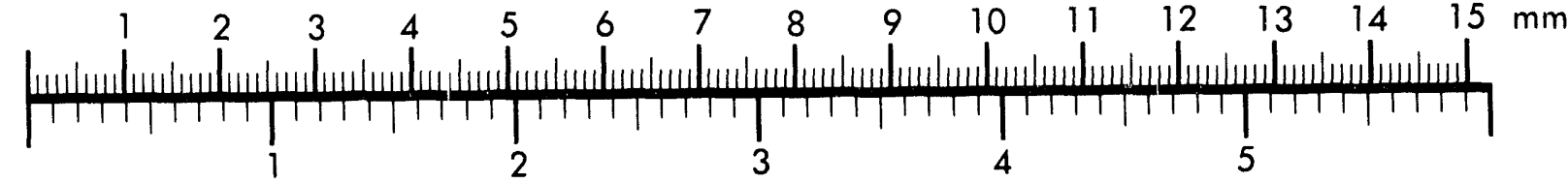

Inches
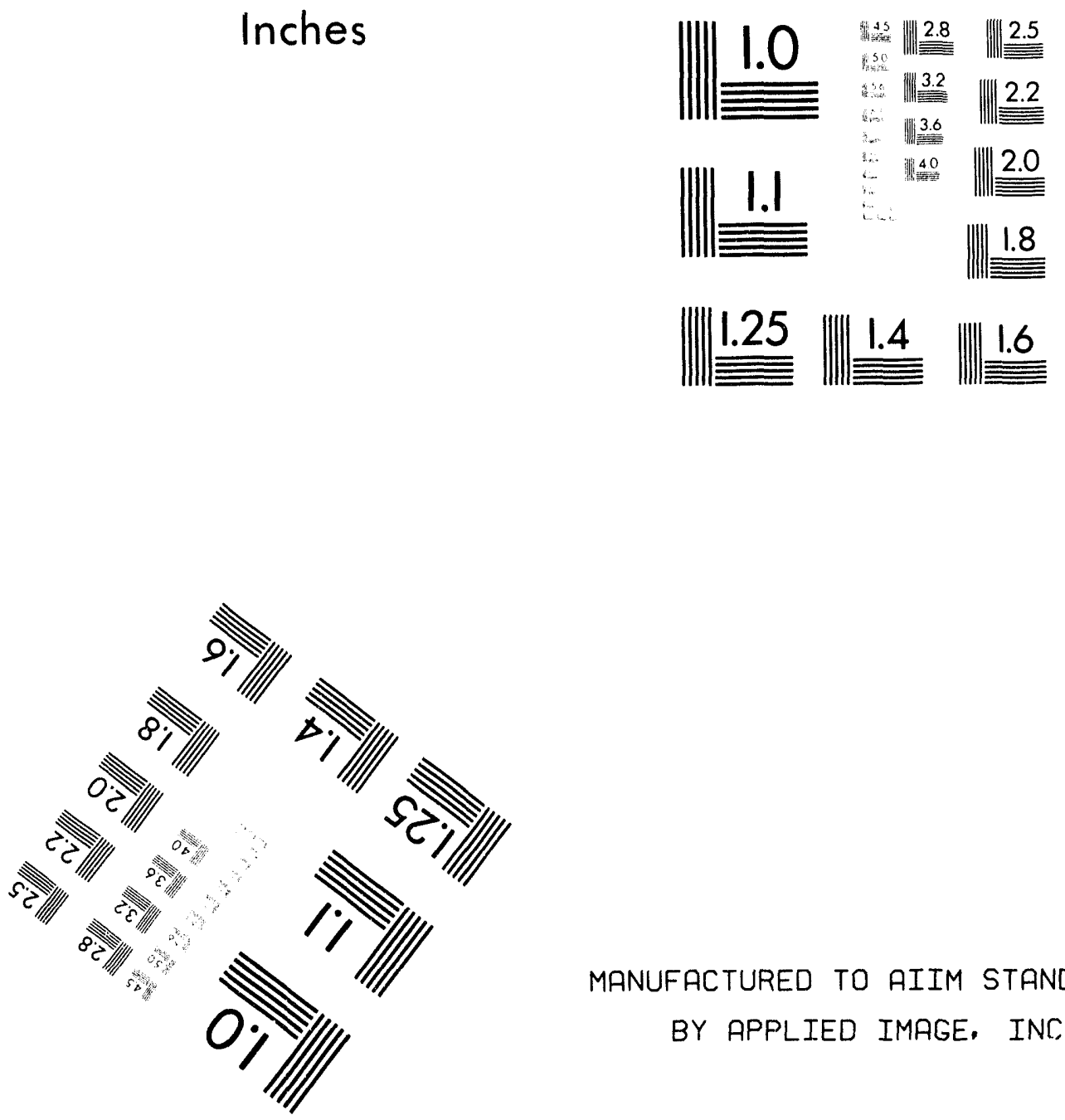

MANUFACTURED TO AIIM STANDARDS

BY APPLIED IMAGE, INC.

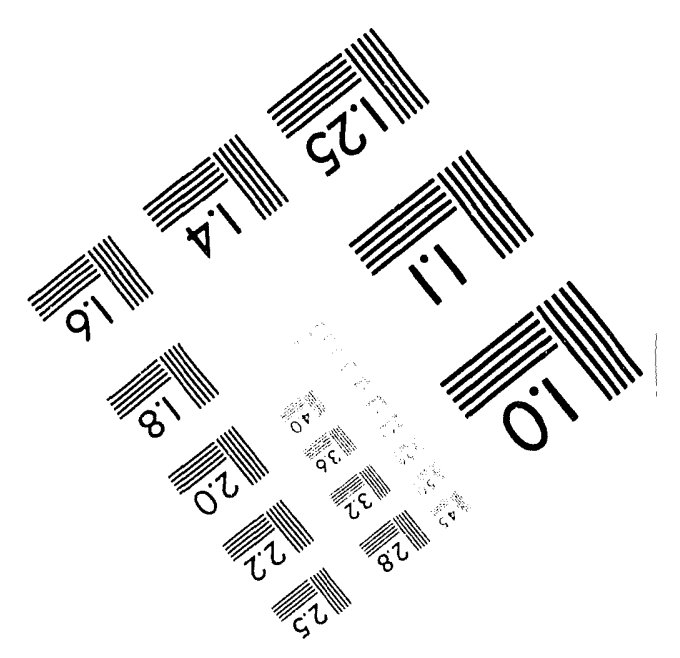



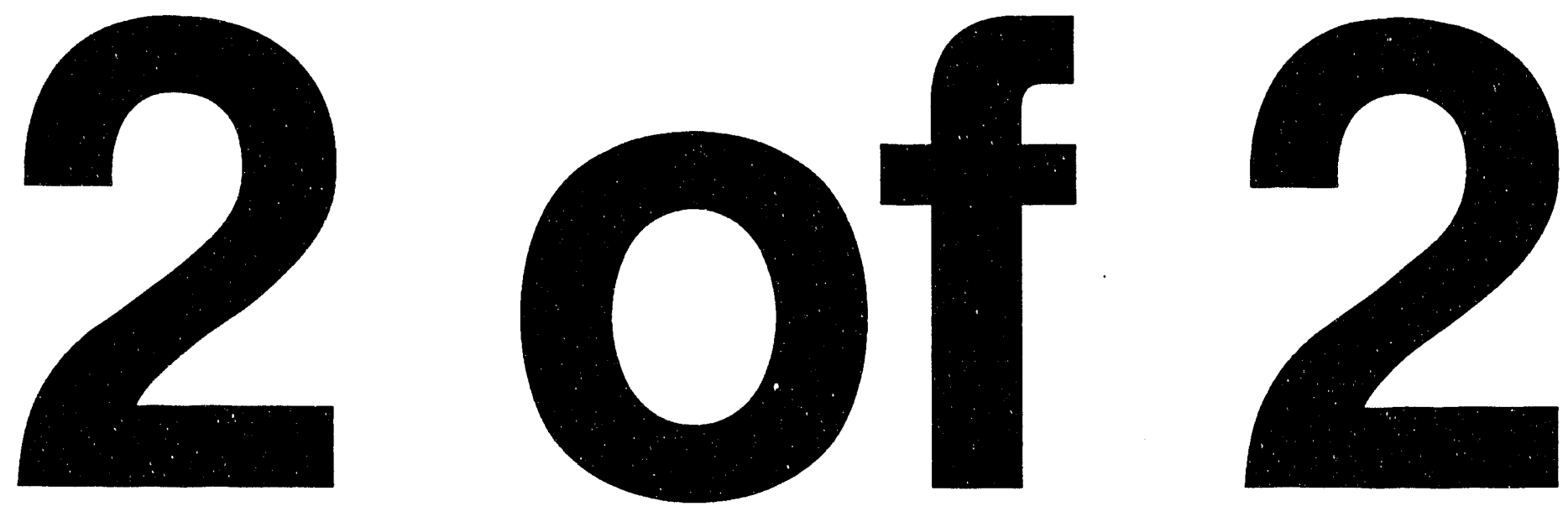
TABLE C.3 Pathology Codes (Used with Autopsy Code 1 or 2, but not 3)

\begin{tabular}{ccccc}
\hline & & & Combined & \\
& Pre- & Pathology & Group Code \\
& JANUS & JANUS & File and & Group Cong \\
& Code & Code & Group Code & Definition \\
\hline
\end{tabular}

Inflammatory Disesses

Enteritis

Hepatitis

Nephritis

Pneumonia

Pseudotuberculosis

Miscellaneous

Non-Inflammatory Diseases

Chronic hepatitis

Chronic nephritis

Amyloidosis

Anemia

Miscellaneous

Dermatitis

Tumors

Leukemia, thymic

Leukemia, non-thymic

Ovarian

Pulmonary

Liver

Intestinal tract

Skin, connective tissue, muscle, bone

Mammary

Miscellaneous

$\begin{array}{llll}11 & \text { ENT } & \text { E }<\text { O_NT> } & \text { Other non-tumor } \\ 12 & \text { HEP } & \text { E }<\text { MHEP> } & \text { Hepatitis } \\ 13 & \text { Note a } & \text { E }<\text { MCRD } & \text { Renal disease } \\ 14 & \text { PNU } & \text { E }<\text { MPNU> } & \text { Pneumonia } \\ 15 & \text { NEC } & \text { E }<\text { O_NT> } & \text { Other non-tumor } \\ 16 & \text { ACI } & \text { E }<\text { O_NT> } & \text { Other non-tumor }\end{array}$

$\begin{array}{llll}21 & \text { CIR } & \text { E }<\text { MHEP> } & \text { Hepatitis } \\ 22 & \text { CRD } & \text { E }<\text { MCRD> } & \text { Renal disease } \\ 23 & \text { AMY } & \text { E }<\text { MAMY> } & \text { Amyloidosis } \\ 24 & \text { ANE } & \text { E }<\text { O_NT> } & \text { Other non-tumor } \\ 25 & \text { MIS } & \text { E }<\text { O_NT> } & \text { Other non-tumor } \\ 26 & \text { DER } & \text { E }<\text { O_NT> } & \text { Other non-tumor }\end{array}$

31 TTY_ $\quad \mathrm{E}<\mathrm{LR}_{-} \mathrm{T}>$

Lymphoreticular tumors

$32 \quad \mathrm{NTY}_{-} \quad \mathrm{E}<\mathrm{LR}_{-} \mathrm{T}>\quad$ Lymphoreticular tumors

33 TOVE $\mathrm{E}<\mathrm{TOVE}>$

Ovarian tumors

34 TADN $\mathrm{E}<\mathrm{TADN}>$

Respiratory

tumors

35 TLIV $E<$ TLIV $>$

Liver tumors

36 TMID E $<$ TGI_>

Gastrointestinal

tract tumors

$37 \quad$ TMIC $\quad \mathrm{E}<\mathrm{TCON}>$

Connective tissue tumors

38 TMGL $\quad \mathrm{E}$ <TMAM>

Mammary gland tumors

39 TMIS $\mathrm{E}<\mathrm{TEPO}>$ 
TABLE C.3 (Cont.)

\begin{tabular}{|c|c|c|c|c|}
\hline Pathology & $\begin{array}{l}\text { Pre- } \\
\text { JANUS } \\
\text { Code }\end{array}$ & $\begin{array}{l}\text { JANUS } \\
\text { Code }\end{array}$ & $\begin{array}{l}\text { Combined } \\
\text { Pathology } \\
\text { File and } \\
\text { Group Code }\end{array}$ & $\begin{array}{l}\text { Group Code } \\
\text { Definition }\end{array}$ \\
\hline \multicolumn{5}{|c|}{ Additional Codes by Fry for GCM-12 } \\
\hline Adrenal tumor & 50 & TADR & $\mathrm{E}<\mathrm{TADR}>$ & Adrenal tumors \\
\hline Adrenal metaplasia & 51 & $\mathrm{ADR}$ & $\mathrm{E}<\mathrm{O} \_\mathrm{NT}>$ & Other non-tumor \\
\hline Adrenal tissue saved & 52 & - & - & \\
\hline Ovarian cyst & 53 & Note a & $\mathrm{E}<\mathrm{MOCY}>$ & Ovarian cyst \\
\hline Hemangioma & 54 & TVAS & $\mathrm{E}<\mathrm{TVAS}>$ & Vascular tumors \\
\hline Atrial thrombus & 55 & THR & $\mathrm{E}<\mathrm{MCVD}>$ & $\begin{array}{l}\text { Cardiovascular } \\
\text { disease }\end{array}$ \\
\hline Secondary in lung & 56 & Note a & $\mathrm{H}<\mathrm{TRW}>>$ & Metastases in lung \\
\hline Bone tumor & 57 & TBON & $\mathrm{H}\langle\mathrm{TBON}\rangle$ & Bone tumors \\
\hline Connective tissue tumor & 58 & TCON & $\mathrm{E}<\mathrm{TCON}>$ & $\begin{array}{l}\text { Connective tissue, } \\
\text { excl. LR_T and } \\
\text { TVAS }\end{array}$ \\
\hline Eliminate & 30 & $\mathrm{CDU}$ & $\mathrm{E}<\mathrm{MCDU}>$ & $\begin{array}{l}\text { Cause of death } \\
\text { unknown }\end{array}$ \\
\hline Unknown & All 0's & $\mathrm{CDU}$ & $\mathrm{E}<\mathrm{MCDU}>$ & $\begin{array}{l}\text { Cause of death } \\
\text { unknown }\end{array}$ \\
\hline Added by Grahn and Wright & 66 & - & - & $\begin{array}{l}\text { Lost record, } \\
\text { autopsy code } 1\end{array}$ \\
\hline
\end{tabular}

a No JANUS MACRO code equivalent. 
TABLe C.4 Pre-JANUS Pathology Codes (Used with Autopsy Code 1 or 2, but not 3) with SNOMED Codes Assigned

\begin{tabular}{ccccc} 
& & & Pre- & Pre- \\
& Pre- & & Pre & JANUS \\
Pathology & JANUS & JANUS & JANUS \\
& Code & Code & TOPOG & MORPH \\
\hline
\end{tabular}

Inflammatory Diseases

Enteritis
Hepatitis
Nephritis
Pneumonia
Pseudotuberculosis
Miscellaneous

Non-Inflammatory Diseases

Chronic hepatitis

Chronic nephritis

Amyloidosis

Anemia

Miscellaneous

Dermatitis

Tumors

Leukemia, thymic

Leukemia, non-thymic

Ovarian

Pulmonary

Liver

Intestinal tract

Skin, connective tissue, muscle, bone

Mammary

Miscellaneous

Additional Codes by Fry for GCM-12

Adrenal tumor

Adrenal metaplasia

Adrenal tissue saved

Ovarian cyst

Hemangioma

Atrial thrombus

Secondary in lung

Bone tumor

Connective tissue tumor

Eliminate

$\begin{array}{llll}11 & \text { ENT } & 50500 & \text { M40000 } \\ 12 & \text { HEP } & 56000 & \text { M41000 } \\ 13 & \text { Note a } & 71000 & \text { M40000 } \\ 14 & \text { PNU } & 28000 & \text { M40000 } \\ 15 & \text { NEC } & 00003 & \text { M54000 } \\ 16 & \text { ACI } & 00003 & \text { M41400 }\end{array}$

$\begin{array}{llll}21 & \text { CIR } & 56000 & \text { M49500 } \\ 22 & \text { CRD } & 71000 & \text { M43000 } \\ 23 & \text { AMY } & 00003 & \text { M55100 } \\ 24 & \text { ANE } & 00010 & \text { M40100 } \\ 25 & \text { MIS } & 00003 & \text { M00010 } \\ 26 & \text { DER } & 01000 & \text { M40000 }\end{array}$

$\begin{array}{llll}31 & \text { TTY_b }_{-} & 00020 & \text { MYY953 } \\ 32 & \text { NTY } & 00020 & \text { MYY933 } \\ 33 & \text { TOVE } & 87000 & \text { M80001 } \\ 34 & \text { TADN } & 28000 & \text { M80001 } \\ 35 & \text { TLIV } & 56000 & \text { M80001 } \\ 36 & \text { TMID } & 50000 & \text { M80001 } \\ 37 & \text { TMIC } & 1 \text { X005 } & \text { M80001 } \\ 38 & \text { TMGL } & 04000 & \text { M80001 } \\ 39 & \text { TMIS } & 00003 & \text { M80001 }\end{array}$

$\begin{array}{llcl}50 & \text { TADR } & 93000 & \text { M80001 } \\ 51 & \text { ADR } & 93000 & \text { M00010 } \\ 52 & - & - & - \\ 53 & \text { Note a } & 87000 & \text { M33400 } \\ 54 & \text { TVAS } & 40000 & \text { M80001 } \\ 55 & \text { THR } & 30000 & \text { M35100 } \\ 56 & \text { Note a } & 28000 & \text { M80006 } \\ 57 & \text { TBON } & 1 \text { X500 } & \text { M80001 } \\ 58 & \text { TCON } & 1 \text { X200 } & \text { M80001 } \\ 30 & \text { CDU } & 00010 & \text { FY3500 }\end{array}$


TABLE C.4 (Cont.)

\begin{tabular}{lcccc}
\hline & \multicolumn{1}{c}{$\begin{array}{c}\text { Pre- } \\
\text { JANUS } \\
\text { Code }\end{array}$} & $\begin{array}{c}\text { JANUS } \\
\text { Code }\end{array}$ & $\begin{array}{c}\text { Pre- } \\
\text { JANUS } \\
\text { TOPOG }\end{array}$ & $\begin{array}{c}\text { Pre- } \\
\text { JANUS } \\
\text { MORPH }\end{array}$ \\
\hline $\begin{array}{l}\text { Unknown } \\
\text { Added by Grahn and Wright }\end{array}$ & All 0'S & CDU & 00010 & FY3500 \\
\hline
\end{tabular}

a No JANUS MACRO code equivalent, so the SNOMED was coded for the pre-JANUS definition.

b Used TTYG and NTYG SNOMED codes. 
TABLE C.5 Pre-JANUS Radiation Protocol

\begin{tabular}{|c|c|c|c|c|c|c|c|}
\hline $\begin{array}{c}\text { Expt. } \\
\text { No. }\end{array}$ & $\begin{array}{l}\text { Treatment } \\
\text { Code }\end{array}$ & $\begin{array}{l}\text { Radiation } \\
\text { Quality }^{\mathrm{a}}\end{array}$ & $\begin{array}{l}\text { Rads } \\
\text { (total) }\end{array}$ & $\begin{array}{l}\text { Time } \\
(\min )\end{array}$ & $\begin{array}{l}\text { Frac- } \\
\text { tions }\end{array}$ & $\begin{array}{l}\text { Fraction/ } \\
\text { unit time }\end{array}$ & Comments $\mathrm{s}^{\mathrm{c}}$ \\
\hline 51 & $0 A$ & $G$ & 134.50 & 60 & 1 & & $150 \mathrm{R}^{\mathrm{d}}$ \\
\hline 51 & $\mathrm{OB}$ & G & 268.99 & 60 & 1 & & $300 \mathrm{R}^{\mathrm{d}}$ \\
\hline 51 & $0 \mathrm{C}$ & $\mathrm{G}$ & 403.49 & 60 & 1 & & $450 \mathrm{R}^{\mathrm{d}}$ \\
\hline 51 & $2 \mathrm{C}$ & $G$ & 403.49 & 60 & 2 & $1 / 3 \mathrm{~h}$ & $450 \mathrm{R}^{\mathrm{d}}$ \\
\hline 51 & $3 \mathrm{C}$ & $\mathrm{G}$ & 403.49 & 60 & 2 & $1 / 10 \mathrm{~h}$ & $450 \mathrm{R}^{\mathrm{d}}$ \\
\hline 51 & $4 C$ & $\mathrm{G}$ & 403.49 & 60 & 2 & $1 / \mathrm{d}$ & $450 \mathrm{R}^{\mathrm{d}}$ \\
\hline 51 & $5 C$ & $\mathrm{G}$ & 403.49 & 60 & 2 & $1 / 3 d$ & $450 \mathrm{R}^{\mathrm{d}}$ \\
\hline 51 & $6 \mathrm{C}$ & G & 403.49 & 60 & 2 & $1 / 5 \mathrm{~d}$ & $450 \mathrm{R}^{\mathrm{d}}$ \\
\hline 51 & $7 \mathrm{C}$ & G & 403.49 & 60 & 2 & $1 / w$ & $450 R^{d}$ \\
\hline 51 & $8 C$ & G & 403.49 & 60 & 2 & $1 / 2 w$ & $450 \mathrm{R}^{\mathrm{d}}$ \\
\hline 51 & $9 \mathrm{C}$ & G & 403.49 & 60 & 2 & $1 / 4 w$ & $450 \mathrm{R}^{\mathrm{d}}$ \\
\hline 51 & OD & $\mathrm{G}$ & 537.98 & 60 & 1 & & $600 \mathrm{R}^{\mathrm{d}}$ \\
\hline 51 & $\mathrm{OF}$ & $\mathrm{G}$ & 672.48 & 60 & 1 & & $750 \mathrm{R}^{\mathrm{d}}$ \\
\hline 51 & $2 \mathrm{~F}$ & $\mathrm{G}$ & 672.48 & 60 & 2 & $1 / 3 \mathrm{~h}$ & $750 \mathrm{R}^{\mathrm{d}}$ \\
\hline 51 & $3 F$ & G & 672.48 & 60 & 2 & $\mathrm{~V} / \mathrm{doh}$ & $750 \mathrm{R}^{\mathrm{d}}$ \\
\hline 51 & $4 \mathrm{~F}$ & G & 672.48 & 60 & 2 & $1 / \mathrm{d}$ & $750 \mathrm{R}^{\mathrm{d}}$ \\
\hline 51 & $5 F$ & G & 672.48 & 60 & 2 & $1 / 3 d$ & $750 \mathrm{R}^{\mathrm{d}}$ \\
\hline 51 & $6 F$ & G & 672.48 & 60 & 2 & $1 / 5 \mathrm{~d}$ & $750 \mathrm{R}^{\mathrm{d}}$ \\
\hline 51 & $7 \mathrm{~F}$ & $\mathrm{G}$ & 672.48 & 60 & 2 & $1 / w$ & $750 \mathrm{R}^{\mathrm{d}}$ \\
\hline 51 & $8 F$ & $\mathrm{G}$ & 672.48 & 60 & 2 & $1 / 2 w$ & $750 \mathrm{R}^{\mathrm{d}}$ \\
\hline 51 & $9 F$ & $\mathrm{G}$ & 672.48 & 60 & 2 & $1 / 4 w$ & $750 \mathrm{R}^{\mathrm{d}}$ \\
\hline 51 & $\mathrm{ON}$ & $\mathrm{G}$ & 134.50 & 60 & 1 & & $150 \mathrm{R}^{\mathrm{e}}$ \\
\hline 51 & $\mathrm{OP}$ & $\mathrm{G}$ & 268.99 & 60 & 1 & & $300 R^{\mathrm{e}}$ \\
\hline 51 & $0 Q$ & G & 403.49 & 60 & 1 & & $450 \mathrm{R}^{\mathrm{e}}$ \\
\hline 51 & $2 Q$ & $\mathrm{G}$ & 403.49 & 60 & 2 & $1 / 3 \mathrm{~h}$ & $450 \mathrm{R}^{\mathrm{e}}$ \\
\hline 51 & $3 \mathbf{Q}$ & $\mathrm{G}$ & 403.49 & 60 & 2 & $1 / 10 \mathrm{~h}$ & $450 \mathrm{R}^{\mathrm{e}}$ \\
\hline 51 & $4 Q$ & G & 403.49 & 60 & 2 & $1 / d$ & $450 \mathrm{R}^{\mathrm{e}}$ \\
\hline 51 & $5 Q$ & G & 403.49 & 60 & 2 & $1 / 3 d$ & $450 \mathrm{R}^{\mathrm{e}}$ \\
\hline 51 & $6 Q$ & $\mathrm{G}$ & 403.49 & 60 & 2 & $1 / 5 \mathrm{~d}$ & $450 \mathrm{R}^{\mathrm{e}}$ \\
\hline 51 & $7 Q$ & G & 403.49 & 60 & 2 & $1 / w$ & $450 \mathrm{R}^{\mathrm{e}}$ \\
\hline 51 & $8 \mathrm{Q}$ & $\mathrm{G}$ & 403.49 & 60 & 2 & $1 / 2 w$ & $450 \mathrm{R}^{\mathrm{e}}$ \\
\hline 51 & $9 Q$ & G & 403.49 & 60 & 2 & $1 / 4 w$ & $450 \mathrm{R}^{\mathrm{e}}$ \\
\hline 51 & OR & G & 537.98 & 60 & 1 & & $600 \mathrm{R}^{\mathrm{e}}$ \\
\hline 51 & $0 \mathrm{~S}$ & G & 672.48 & 60 & 1 & & $750 \mathrm{R}^{\mathrm{e}}$ \\
\hline 51 & $2 S$ & $\mathrm{G}$ & 672.48 & 60 & 2 & $1 / 3 h$ & $750 \mathrm{R}^{\mathrm{e}}$ \\
\hline 51 & $3 S$ & $G$ & 672.48 & 60 & 2 & $\mathrm{v} / 10 \mathrm{~h}$ & $750 \mathrm{R}^{\mathrm{e}}$ \\
\hline 51 & $4 S$ & $\mathrm{G}$ & 672.48 & 60 & 2 & $1 / d$ & $750 \mathrm{R}^{\mathrm{e}}$ \\
\hline 51 & $5 \mathrm{~S}$ & $\mathrm{G}$ & 672.48 & 60 & 2 & $1 / 3 d$ & $750 \mathrm{R}^{\mathrm{e}}$ \\
\hline 51 & $6 S$ & G & 672.48 & 60 & 2 & $1 / 5 \mathrm{~d}$ & $750 \mathrm{R}^{\mathrm{e}}$ \\
\hline 51 & $7 \mathrm{~S}$ & G & 672.48 & 60 & 2 & $1 / w$ & $750 \mathrm{R}^{\mathrm{e}}$ \\
\hline 51 & $8 \mathrm{~S}$ & G & 672.48 & 60 & 2 & $1 / 2 w$ & $750 \mathrm{R}^{\mathrm{e}}$ \\
\hline 51 & $9 \mathrm{~S}$ & $\mathrm{G}$ & 672.48 & 60 & 2 & $1 / 4 w$ & $750 \mathrm{R}^{\mathrm{e}}$ \\
\hline 51 & OT & G & 134.50 & 60 & 1 & & $150 \mathrm{R}^{\mathrm{f}}$ \\
\hline 51 & $0 \mathrm{U}$ & G & 268.99 & 60 & 1 & & $300 \mathrm{R}^{\mathrm{f}}$ \\
\hline 51 & oV & $\mathrm{G}$ & 403.49 & 60 & 1 & & $450 \mathrm{R}^{\mathrm{f}}$ \\
\hline 51 & $2 \mathrm{~V}$ & $\mathrm{G}$ & 403.49 & 60 & 2 & $1 / 3 \mathrm{~h}$ & $450 \mathrm{R}^{\mathrm{f}}$ \\
\hline
\end{tabular}


TABLE C.5 (Cont.)

\begin{tabular}{|c|c|c|c|c|c|c|c|}
\hline $\begin{array}{c}\text { Expt. } \\
\text { No. }\end{array}$ & $\begin{array}{l}\text { Treatment } \\
\text { Code }\end{array}$ & $\begin{array}{l}\text { Radiation } \\
\text { Quality }^{\mathrm{a}}\end{array}$ & $\begin{array}{l}\text { Rads } \\
\text { (total) }\end{array}$ & $\begin{array}{l}\text { Time } \\
(\min )\end{array}$ & $\begin{array}{l}\text { Frac- } \\
\text { tions }\end{array}$ & $\begin{array}{c}\text { Fraction/ } \\
\text { unit time }^{\text {b }}\end{array}$ & Comments $^{\mathrm{c}}$ \\
\hline 51 & $3 V$ & G & 403.49 & 60 & 2 & $1 / 10 \mathrm{~h}$ & $450 \mathrm{R}^{\mathrm{f}}$ \\
\hline 51 & $4 \mathrm{~V}$ & $\bar{G}$ & 403.49 & 60 & 2 & $\mathrm{~V} / \mathrm{d}$ & $450 \mathrm{R}^{\mathrm{f}}$ \\
\hline 51 & $5 \mathrm{~V}$ & G & 403.49 & 60 & 2 & $1 / 3 d$ & $450 \mathrm{R}^{\mathrm{f}}$ \\
\hline 51 & $6 \mathrm{~V}$ & G & 403.49 & 60 & 2 & $1 / 5 \mathrm{~d}$ & $450 \mathrm{R}^{f}$ \\
\hline 51 & $7 \mathrm{~V}$ & G & 403.49 & 60 & 2 & $1 / w$ & $450 \mathrm{R}^{\mathrm{f}}$ \\
\hline 51 & $8 \mathrm{~V}$ & $\mathbf{G}$ & 403.49 & 60 & 2 & $1 / 2 w$ & $450 \mathrm{R}^{\mathrm{f}}$ \\
\hline 51 & $9 \mathrm{~V}$ & G & 403.49 & 60 & 2 & $1 / 4 w$ & $450 \mathrm{R}^{\mathrm{f}}$ \\
\hline 51 & ow & G & 537.98 & 60 & 1 & & $600 \mathrm{R}^{\mathrm{f}}$ \\
\hline 51 & $0 \mathrm{X}$ & $G$ & 672.48 & 60 & 1 & & $750 \mathrm{R}^{\mathrm{f}}$ \\
\hline 51 & $2 \mathrm{X}$ & $\mathrm{G}$ & 672.48 & 60 & 2 & $1 / 3 \mathrm{~h}$ & $750 \mathrm{R}^{\mathrm{f}}$ \\
\hline 51 & $3 X$ & $\mathrm{G}$ & 672.48 & 60 & 2 & $\mathrm{v} / 10 \mathrm{~h}$ & $750 \mathrm{R}^{\mathrm{f}}$ \\
\hline 51 & $4 X$ & $\mathrm{G}$ & 672.48 & 60 & 2 & $1 / \mathrm{d}$ & $750 \mathrm{R}^{\mathrm{f}}$ \\
\hline 51 & $5 X$ & G & 672.48 & 60 & 2 & $1 / 3 d$ & $750 \mathrm{R}^{\mathrm{f}}$ \\
\hline 51 & $6 \mathrm{X}$ & G & 672.48 & 60 & 2 & $1 / 5 \mathrm{~d}$ & $750 \mathrm{R}^{\mathrm{f}}$ \\
\hline 51 & $7 \mathrm{X}$ & G & 672.48 & 60 & 2 & $1 / w$ & $750 \mathrm{R}^{\mathrm{f}}$ \\
\hline 51 & $8 X$ & $\mathrm{G}$ & 672.48 & 60 & 2 & $1 / 2 w$ & $750 \mathrm{R}^{\mathrm{f}}$ \\
\hline 51 & $9 X$ & G & 672.48 & 60 & 2 & $1 / 4 w$ & $750 \mathrm{R}^{\mathrm{f}}$ \\
\hline $5 \%$ & $\mathbf{O A}$ & $\mathrm{G}$ & 134.50 & 60 & 1 & & $150 \mathrm{R}$ \\
\hline 52 & OB & G & 268.99 & 60 & 1 & & $300 \mathrm{R}$ \\
\hline 52 & OC & G & 403.49 & 60 & 1 & & $450 \mathrm{R}$ \\
\hline 52 & OD & $\mathrm{G}$ & 537.98 & 60 & 1 & & $600 \mathrm{R}$ \\
\hline 52 & $O E$ & G & 627.65 & 60 & 1 & & $700 \mathrm{R}$ \\
\hline 52 & $\mathrm{OF}$ & G & 672.48 & 60 & 1 & & $750 \mathrm{R}$ \\
\hline 52 & $0 G$ & G & 717.31 & 60 & 1 & & $800 \mathrm{R}$ \\
\hline 52 & $\mathrm{OH}$ & G & 762.14 & 60 & 1 & & $850 \mathrm{R}$ \\
\hline 52 & OI & G & 806.98 & 60 & 1 & & $900 \mathrm{R}$ \\
\hline 52 & OJ & $\mathrm{G}$ & 851.81 & 60 & 1 & & $950 \mathrm{R}$ \\
\hline 52 & OK & $\mathrm{G}$ & 896.64 & 60 & 1 & & $1000 \mathrm{R}$ \\
\hline 52 & $\mathrm{OL}$ & G & 941.47 & 60 & 1 & & $1050 \mathrm{R}$ \\
\hline 52 & $0 \mathrm{M}$ & G & 986.30 & 60 & 1 & & $1100 \mathrm{R}$ \\
\hline 53 & Do & $\mathrm{C}$ & 0 & & 1 & & O R \\
\hline 53 & DA & $\mathbf{X}$ & 348.55 & 18.18 & 1 & & $400 \mathrm{R}$ \\
\hline 53 & DB & $\mathbf{X}$ & 365.98 & 19.09 & 1 & & $20 \mathrm{R}$ \\
\hline 53 & DC & $\mathbf{X}$ & 379.05 & 19.77 & 1 & & $435 \mathrm{R}$ \\
\hline 53 & $\mathrm{DD}$ & $\mathrm{X}$ & 392.12 & 20.45 & 1 & & $450 \mathrm{R}$ \\
\hline 53 & $\mathrm{DE}$ & $\mathrm{X}$ & 409.55 & 21.36 & 1 & & $470 \mathrm{R}$ \\
\hline 53 & $\mathrm{DF}$ & $\mathrm{X}$ & 413.91 & 21.59 & 1 & & $475 \mathrm{R}$ \\
\hline 53 & DG & $\mathrm{X}$ & 418.26 & 21.82 & 1 & & $480 \mathrm{R}$ \\
\hline 53 & $\mathrm{DH}$ & $\mathrm{X}$ & 426.98 & 22.27 & 1 & & $490 \mathrm{R}$ \\
\hline 53 & DI & $\mathrm{X}$ & 431.33 & 22.5 & 1 & & $495 \mathrm{R}$ \\
\hline 53 & DJ & $\mathrm{X}$ & 435.69 & 22.73 & 1 & & $500 \mathrm{R}$ \\
\hline 53 & DK & $\mathrm{X}$ & 444.40 & 23.18 & 1 & & $510 \mathrm{R}$ \\
\hline 53 & $\mathrm{DL}$ & $\mathrm{X}$ & 453.12 & 23.64 & 1 & & $520 \mathrm{R}$ \\
\hline 53 & $\mathrm{DM}$ & $X$ & 457.47 & 23.86 & 1 & & $525 \mathrm{R}$ \\
\hline 53 & DN & $\mathbf{X}$ & 461.83 & 24.09 & 1 & & $530 \mathrm{R}$ \\
\hline 53 & DO & $\mathrm{X}$ & 470.55 & 24.55 & 1 & & $540 \mathrm{R}$ \\
\hline
\end{tabular}


TABLE C.5 (Cont.)

\begin{tabular}{|c|c|c|c|c|c|c|c|}
\hline $\begin{array}{c}\text { Expt. } \\
\text { No. }\end{array}$ & $\begin{array}{c}\text { Treatment } \\
\text { Code } \\
\end{array}$ & $\begin{array}{c}\text { Radiation } \\
\text { Quality }^{\mathrm{a}}\end{array}$ & $\begin{array}{c}\text { Pads } \\
\text { (total) }\end{array}$ & $\begin{array}{l}\text { Time } \\
(\mathrm{min})\end{array}$ & $\begin{array}{l}\text { Frac- } \\
\text { tions }\end{array}$ & $\begin{array}{l}\text { Fraction/ } \\
\text { unit time }^{b}\end{array}$ & Comments $^{c}$ \\
\hline 53 & DP & $\mathbf{X}$ & 479.26 & 25.0 & 1 & & $550 \mathrm{R}$ \\
\hline 53 & DQ & $\mathbf{X}$ & 483.62 & 25.23 & 1 & & $555 \mathrm{R}$ \\
\hline 53 & $\mathrm{DR}$ & $X$ & 492.33 & 25.68 & 1 & & $565 \mathrm{R}$ \\
\hline 53 & DS & $\mathrm{X}$ & 496.69 & 25.91 & 1 & & $570 \mathrm{R}$ \\
\hline 53 & $\mathrm{DT}$ & $\mathrm{X}$ & 501.04 & 26.14 & 1 & & $575 \mathrm{R}$ \\
\hline 53 & DU & $\mathrm{X}$ & 505.40 & 26.36 & 1 & & $580 \mathrm{R}$ \\
\hline 53 & DV & $\mathrm{X}$ & 509.76 & 26.59 & 1 & & $585 \mathrm{R}$ \\
\hline 53 & DW & $\mathrm{X}$ & 514.11 & 26.82 & 1 & & $590 \mathrm{R}$ \\
\hline 53 & DX & $\mathrm{X}$ & 522.83 & 27.27 & 1 & & $600 \mathrm{R}$ \\
\hline 53 & DY & $\mathrm{X}$ & 532.41 & 27.77 & 1 & & $611 \mathrm{R}$ \\
\hline 53 & $\mathrm{DZ}$ & $\mathrm{X}$ & 535.90 & 27.95 & 1 & & $615 \mathrm{R}$ \\
\hline 53 & EA & $\mathrm{X}$ & 544.61 & 28.41 & 1 & & $625 \mathrm{R}$ \\
\hline 53 & EB & $\mathrm{X}$ & 548.97 & 28.64 & 1 & & $630 \mathrm{R}$ \\
\hline 53 & EC & $\mathrm{X}$ & 553.33 & 28.86 & 1 & & $635 \mathrm{R}$ \\
\hline 53 & ED & $\mathrm{X}$ & 562.04 & 29.32 & 1 & & $645 \mathrm{R}$ \\
\hline 53 & $\mathrm{EE}$ & $\mathrm{X}$ & 566.40 & 29.55 & 1 & & $650 \mathrm{R}$ \\
\hline 53 & EF & $\mathrm{X}$ & 575.11 & 30.0 & 1 & & $660 \mathrm{R}$ \\
\hline 53 & EG & $\mathrm{X}$ & 583.82 & 30.45 & i & & $670 \mathrm{R}$ \\
\hline 53 & $\mathrm{EH}$ & $\mathrm{X}$ & 588.18 & 30.68 & 1 & & $675 \mathrm{R}$ \\
\hline 53 & EI & $\mathrm{X}$ & 601.25 & 31.36 & 1 & & $690 \mathrm{R}$ \\
\hline 53 & EJ & $\mathrm{X}$ & 609.97 & 31.82 & 1 & & $700 \mathrm{R}$ \\
\hline 53 & EK & $\mathrm{X}$ & 614.32 & 32.05 & 1 & & $705 \mathrm{R}$ \\
\hline 53 & EL & $\mathrm{X}$ & 618.68 & 32.27 & 1 & & $710 \mathrm{R}$ \\
\hline 53 & EM & $\mathrm{X}$ & 627.39 & 32.72 & 1 & & $720 \mathrm{R}$ \\
\hline 53 & $\mathrm{EN}$ & $\mathrm{X}$ & 631.75 & 32.95 & 1 & & $725 \mathrm{R}$ \\
\hline 53 & EO & $\mathrm{X}$ & 640.46 & 33.41 & 1 & & $735 \mathrm{R}$ \\
\hline 53 & EP & $\mathrm{X}$ & 653.54 & 34.09 & 1 & & $750 \mathrm{R}$ \\
\hline 53 & $\mathrm{EQ}$ & $\mathrm{X}$ & 670.96 & 35.0 & 1 & & $770 \mathrm{R}$ \\
\hline 53 & ER & $\mathrm{X}$ & 675.32 & 35.23 & 1 & & $775 \mathrm{R}$ \\
\hline 53 & ES & $\mathrm{X}$ & 697.10 & 36.36 & 1 & & $800 \mathrm{R}$ \\
\hline 53 & ET & $\mathrm{X}$ & 740.67 & 38.64 & 1 & & $850 \mathrm{R}$ \\
\hline 53 & EU & $\mathrm{X}$ & 784.24 & 40.91 & 1 & & $900 \mathrm{R}$ \\
\hline 54 & AO & $\mathrm{C}$ & 0 & 600 & 999 & $1 / d$ & $0 \mathrm{R} / \mathrm{d}$ \\
\hline 54 & $\mathbf{A A}$ & G & 4.48 & 600 & 999 & $\mathrm{~V} / \mathrm{d}$ & $5 \mathrm{R} / \mathrm{d}$ \\
\hline 54 & $A B$ & G & 10.76 & 600 & 999 & $1 / d$ & $12 \mathrm{R} / \mathrm{d}$ \\
\hline 54 & $\mathrm{AC}$ & $\mathrm{G}$ & 21.52 & 600 & 999 & $1 / d$ & $24 \mathrm{R} / \mathrm{d}$ \\
\hline 54 & $\mathrm{AD}$ & $\mathrm{G}$ & 28.69 & 600 & 999 & $1 / d$ & $32 \mathrm{R} / \mathrm{d}$ \\
\hline 54 & $\overline{A E}$ & $\mathrm{G}$ & 38.56 & 600 & 999 & $\mathrm{vd}$ & $43 \mathrm{R} / \mathrm{d}$ \\
\hline 54 & $\mathrm{AF}$ & G & 43.94 & 600 & 999 & $1 / d$ & $49 \mathrm{R} / \mathrm{d}$ \\
\hline 54 & AG & $\mathrm{G}$ & 50.21 & 600 & 999 & $1 / d$ & $56 \mathrm{R} / \mathrm{d}$ \\
\hline 54 & $\mathrm{AH}$ & $\mathrm{G}$ & 57.38 & 600 & 999 & $1 / d$ & $64 \mathrm{R} / \mathrm{d}$ \\
\hline 54 & $\mathrm{AI}$ & $\mathrm{G}$ & 66.35 & 600 & 999 & $1 / d$ & $74 \mathrm{R} / \mathrm{d}$ \\
\hline 54 & AJ & G & 76.21 & 600 & 999 & $1 / d$ & $85 \mathrm{R} / \mathrm{d}$ \\
\hline 54 & $\mathrm{AK}$ & $\mathrm{G}$ & 86.97 & 600 & 999 & $1 / d$ & $97 \mathrm{R} / \mathrm{d}$ \\
\hline 54 & $\mathrm{AL}$ & G & 112.08 & 600 & 999 & $1 / d$ & $125 \mathrm{R} / \mathrm{d}$ \\
\hline 54 & $\mathrm{AM}$ & G & 130.01 & 600 & 999 & $1 / d$ & $145 \mathrm{R} / \mathrm{d}$ \\
\hline 54 & AN & G & 152.42 & 600 & 999 & $1 / d$ & $170 \mathrm{R} / \mathrm{d}$ \\
\hline 54 & $\mathrm{AO}$ & $\mathrm{G}$ & 197.26 & 600 & 999 & $1 / d$ & $220 \mathrm{R} / \mathrm{d}$ \\
\hline 54 & AP & $\mathrm{G}$ & 242.09 & 600 & 999 & $1 / d$ & $270 \mathrm{R} / \mathrm{d}$ \\
\hline 54 & $\mathrm{AQ}$ & $\mathrm{G}$ & 295.89 & 600 & 999 & $1 / d$ & $330 \mathrm{R} / \mathrm{d}$ \\
\hline
\end{tabular}


TABLE C.5 (Cont.)

\begin{tabular}{|c|c|c|c|c|c|c|c|}
\hline $\begin{array}{c}\text { Expt. } \\
\text { No. }\end{array}$ & $\begin{array}{c}\text { Treatment } \\
\text { Code }\end{array}$ & $\begin{array}{c}\text { Radiation } \\
\text { Quality }^{\mathbf{a}}\end{array}$ & $\begin{array}{l}\text { Rads } \\
\text { (total) }\end{array}$ & $\begin{array}{l}\text { Time } \\
(\min )\end{array}$ & $\begin{array}{l}\text { Frac- } \\
\text { tions }\end{array}$ & $\begin{array}{l}\text { Fraction/ } \\
\text { unit time }\end{array}$ & Comments ${ }^{c}$ \\
\hline 54 & $\mathrm{AR}$ & G & 367.62 & 600 & 999 & $1 / d$ & $410 \mathrm{R} / \mathrm{d}$ \\
\hline 54 & AS & G & 448.32 & 600 & 999 & $1 / d$ & $500 \mathrm{R} / \mathrm{d}$ \\
\hline 54 & AT & G & 546.95 & 600 & 999 & $1 / d$ & $610 \mathrm{R} / \mathrm{d}$ \\
\hline 54 & $\mathrm{AU}$ & G & 672.48 & 600 & 999 & $1 / d$ & $750 \mathrm{R} / \mathrm{d}$ \\
\hline 54 & AV & G & 986.30 & 600 & 999 & $1 / \mathrm{d}$ & $1100 \mathrm{R} / \mathrm{d}$ \\
\hline 54 & AW & G & 1479.46 & 600 & 999 & $1 / d$ & $1650 \mathrm{R} / \mathrm{d}$ \\
\hline 54 & $\mathrm{AX}$ & G & 2241.60 & 600 & 999 & $1 / d$ & $2500 \mathrm{R} / \mathrm{d}$ \\
\hline 58 & BO & $\mathrm{C}$ & 0 & 600 & 999 & $1 / d$ & $0 \mathrm{R} / \mathrm{d}$ \\
\hline 58 & BA & G & 4.48 & 600 & 999 & $1 / d$ & $5 \mathrm{R} / \mathrm{d}$ \\
\hline 58 & BB & G & 10.76 & 600 & 999 & $1 / d$ & $12 \mathrm{R} / \mathrm{d}$ \\
\hline 58 & $\mathrm{BC}$ & G & 21.52 & 600 & 999 & $1 / \mathrm{d}$ & $24 \mathrm{R} / \mathrm{d}$ \\
\hline 58 & $\mathrm{BD}$ & G & 28.69 & 600 & 999 & $1 / d$ & $32 \mathrm{R} / \mathrm{d}$ \\
\hline 58 & $\mathrm{BE}$ & G & 35.56 & 600 & 999 & $1 / d$ & $43 \mathrm{R} / \mathrm{d}$ \\
\hline 58 & $\mathrm{BF}$ & G & 50.21 & 600 & 999 & $1 / d$ & $56 \mathrm{R} / \mathrm{d}$ \\
\hline 58 & BG & $\mathbf{G}$ & 57.38 & 600 & 999 & $1 / d$ & $64 \mathrm{R} / \mathrm{d}$ \\
\hline 58 & $\mathrm{BH}$ & $\mathbf{G}$ & 66.35 & 600 & 999 & $1 / d$ & $74 \mathrm{R} / \mathrm{d}$ \\
\hline 58 & BI & G & 76.21 & 600 & 999 & $1 / d$ & $85 \mathrm{R} / \mathrm{d}$ \\
\hline 58 & $\mathrm{BJ}$ & $G$ & 86.97 & 600 & 999 & $1 / d$ & $97 \mathrm{R} / \mathrm{d}$ \\
\hline 58 & BK & G & 112.08 & 600 & 999 & $1 / d$ & $125 \mathrm{R} / \mathrm{d}$ \\
\hline 58 & $\mathrm{BL}$ & G & 152.43 & 600 & 999 & $1 \mathrm{~d}$ & $170 \mathrm{R} / \mathrm{d}$ \\
\hline 58 & $\mathrm{BM}$ & G & 197.26 & 600 & 999 & $1 / d$ & $220 \mathrm{R} / \mathrm{d}$ \\
\hline 62 & CO & $\mathrm{C}$ & 0 & 600 & 999 & $1 / d$ & $0 \mathrm{R} / \mathrm{d}$ \\
\hline 62 & $\mathrm{CA}$ & G & 0.27 & 600 & 999 & $\mathrm{Vd}$ & $0.3 \mathrm{R} / \mathrm{d}$ \\
\hline 62 & $\mathrm{CB}$ & G & 1.17 & 600 & 999 & $1 / d$ & $1.3 \mathrm{R} / \mathrm{d}$ \\
\hline 62 & $\mathrm{CC}$ & $G$ & 2.33 & 600 & 999 & $1 / d$ & $2.6 \mathrm{R} / \mathrm{d}$ \\
\hline 62 & $\mathrm{CD}$ & G & 5.38 & 600 & 999 & $1 / d$ & $6 \mathrm{R} / \mathrm{d}$ \\
\hline 62 & $\mathrm{CE}$ & $G$ & 10.76 & 600 & 999 & $1 / d$ & $12 \mathrm{R} / \mathrm{d}$ \\
\hline 62 & CF & $\mathrm{G}$ & 21.52 & 600 & 999 & $1 / d$ & $24 \mathrm{R} / \mathrm{d}$ \\
\hline 62 & CG & G & 28.69 & 600 & 999 & $1 / d$ & $32 \mathrm{R} / \mathrm{d}$ \\
\hline 62 & $\mathrm{CH}$ & G & 38.56 & 600 & 999 & $1 / d$ & $43 \mathrm{R} / \mathrm{d}$ \\
\hline 62 & $\mathrm{CI}$ & G & 50.21 & 600 & 999 & $1 / d$ & $56 \mathrm{R} / \mathrm{d}$ \\
\hline 62 & CJ & G & 66.35 & 600 & 999 & $1 / \mathrm{d}$ & $74 \mathrm{R} / \mathrm{d}$ \\
\hline 62 & CK & G & 86.97 & 600 & 999 & $1 / d$ & $97 \mathrm{R} / \mathrm{d}$ \\
\hline 62 & CL & G & 112.08 & 600 & 999 & $1 / \mathrm{d}$ & $125 \mathrm{R} / \mathrm{d}$ \\
\hline
\end{tabular}

a $\mathrm{G}=\gamma$ ray; $\mathrm{C}=$ control; $\mathrm{X}=\mathrm{x}$-ray.

b $h=$ hour; $d=$ day; $w=$ week.

c Roentgen values are original measurements.

d $1=$ day 0 (see Table A.8).

- 2 = day 14 (see Table A.8).

f 3 = day 28 (see Table A.8). 
TABLE C.6 JANUS Radiation Protocol

\begin{tabular}{|c|c|c|c|c|c|c|c|c|}
\hline $\begin{array}{c}\text { Expt. } \\
\text { No. }\end{array}$ & $\begin{array}{l}\text { Treat- } \\
\text { ment } \\
\text { Code }\end{array}$ & $\begin{array}{l}\text { Radia- } \\
\text { tion } \\
\text { Quality }^{a}\end{array}$ & $\begin{array}{l}\text { Rads } \\
\text { (total) }\end{array}$ & $\begin{array}{l}\text { Time } \\
(\mathrm{min})\end{array}$ & $\begin{array}{l}\text { Frac- } \\
\text { tions }\end{array}$ & $\begin{array}{c}\text { Fraction/ } \\
\text { Unit } \\
\text { Time }^{\mathrm{b}}\end{array}$ & $\begin{array}{c}\text { No. of } \\
\text { Repeats }\end{array}$ & Comments \\
\hline 2 & $\mathrm{AC}$ & C & 0 & 15 & 72 & $3 / w$ & & \\
\hline 2 & $\mathrm{DC}$ & C & 0 & 45 & 24 & $1 / w$ & & \\
\hline 2 & EC & C & 0 & 360 & 24 & $1 / w$ & & \\
\hline 2 & $\mathrm{HC}$ & $\mathrm{C}$ & 0 & 180 & 6 & $\mathrm{~V} / \mathrm{m}$ & & \\
\hline 2 & so & C & 0 & 20 & 1 & & & \\
\hline 2 & $\mathrm{AI}$ & G & 855 & 15 & 72 & $3 / w$ & & \\
\hline 2 & $\mathrm{BI}$ & G & 855 & 45 & 24 & $1 / w$ & & \\
\hline 2 & DI & G & 1110 & 45 & 24 & $1 / w$ & & \\
\hline 2 & EI & G & 855 & 360 & 24 & $1 / w$ & & \\
\hline 2 & $\mathrm{HI}$ & G & 855 & 180 & 6 & $1 / \mathrm{m}$ & & \\
\hline 2 & S1 & G & 90 & 20 & 1 & & & \\
\hline 2 & S2 & G & 268 & 20 & 1 & & & \\
\hline 2 & S3 & G & 788 & 20 & 1 & & & \\
\hline 2 & Y2 & G & 268 & 20 & 1 & & & Age $194 \mathrm{~d}$ \\
\hline 2 & Y3 & G & 788 & 20 & 1 & & & Age $194 \mathrm{~d}$ \\
\hline 2 & $\mathrm{Z} 2$ & G & 268 & 20 & 1 & & & Age $287 \mathrm{~d}$ \\
\hline 2 & Z3 & G & 788 & 20 & 1 & & & Age $287 \mathrm{~d}$ \\
\hline 2 & AI & $\mathbf{N}$ & 240 & 15 & 72 & $3 / w$ & & \\
\hline 2 & $\mathrm{BI}$ & $\mathrm{N}$ & 240 & 45 & 24 & $1 / w$ & & \\
\hline 2 & DI & $\mathrm{N}$ & 80 & 45 & 24 & $1 / w$ & & \\
\hline 2 & EI & $\mathrm{N}$ & 240 & 360 & 24 & $1 / w$ & & \\
\hline 2 & $\mathrm{HI}$ & $\mathrm{N}$ & 240 & 180 & 6 & $1 / \mathrm{m}$ & & \\
\hline 2 & S1 & $\mathrm{N}$ & 20 & 20 & 1 & & & \\
\hline 2 & S2 & $\mathbf{N}$ & 80 & 20 & 1 & & & \\
\hline 2 & S3 & $\mathbf{N}$ & 240 & 20 & 1 & & & \\
\hline 2 & Y2 & $\mathrm{N}$ & 80 & 20 & 1 & & & Age $194 \mathrm{~d}$ \\
\hline 2 & Y3 & $\mathrm{N}$ & 240 & 20 & 1 & & & Age $194 \mathrm{~d}$ \\
\hline 2 & Z2 & $\mathrm{N}$ & 80 & 20 & 1 & & & Age $287 \mathrm{~d}$ \\
\hline 2 & $\mathrm{Z3}$ & $\mathrm{N}$ & 240 & 20 & 1 & & & Age $287 \mathrm{~d}$ \\
\hline 3 & So & $\mathrm{C}$ & 0 & 20 & 1 & & & \\
\hline 3 & S4 & G & 90 & 20 & 1 & & & \\
\hline 3 & S5 & $\bar{G}$ & 143 & 20 & 1 & & & Females discarded \\
\hline 3 & S6 & $\vec{G}$ & 206 & 20 & 1 & & & Females discarded \\
\hline 3 & S7 & G & 417 & 20 & 1 & & & \\
\hline 3 & S8 & G & 569 & 20 & 1 & & & Some females discarded \\
\hline 3 & S4 & $\mathbf{N}$ & 20 & 20 & 1 & & & \\
\hline 3 & S5 & $\mathbf{N}$ & 40 & 20 & 1 & & & Females discarded \\
\hline 3 & S6 & $\mathbf{N}$ & 60 & 20 & 1 & & & Fernales discarded \\
\hline 3 & S7 & $\mathbf{N}$ & 120 & 20 & 1 & & & Females discarded \\
\hline 3 & S8 & $\mathbf{N}$ & 160 & 20 & 1 & & & \\
\hline 3 & SL & $\mathrm{N}$ & 240 & 480 & 1 & & & Males, no MICROS \\
\hline 3 & SH & $\mathrm{N}$ & 240 & 20 & 1 & & & Males; no MICROS \\
\hline 4 & KO & $\mathrm{C}$ & 0 & 45 & 24 & $1 / w$ & & \\
\hline 4 & K1 & G & 206 & 45 & 24 & $1 / w$ & & Females reassigned \\
\hline 4 & $\mathrm{~K} 2$ & G & 417 & 45 & 24 & $1 / w$ & & \\
\hline 4 & $\mathrm{~K} 3$ & $\vec{G}$ & 959 & 45 & 24 & $1 / w$ & & Females reassigned \\
\hline 4 & K4 & G & 1919 & 45 & 24 & $1 / w$ & & Most females reassigned \\
\hline 4 & K5 & $\mathrm{G}$ & 3820 & 45 & 24 & $1 / w$ & & $\begin{array}{l}\text { Males \& a few females; } \\
\text { no MICROS }\end{array}$ \\
\hline 4 & K6 & G & 5111 & 45 & 24 & $1 / w$ & & No MICROS \\
\hline 4 & K1 & $\mathrm{N}$ & 20 & 45 & 24 & $1 / w$ & & \\
\hline 4 & $\mathrm{~K} 2$ & $\mathrm{~N}$ & 40 & 45 & 24 & $1 / w$ & & Females reassigned \\
\hline 4 & K3 & $\mathrm{N}$ & 60 & 45 & 24 & $1 / w$ & & Females reassigned \\
\hline 4 & $\mathrm{~K} 4$ & $\mathrm{~N}$ & 120 & 45 & 24 & $1 / w$ & & Females reassigned \\
\hline 4 & $\mathrm{~K} 5$ & $\mathrm{~N}$ & 168 & 45 & 24 & $1 / w$ & & \\
\hline 4 & K6 & $\mathbf{N}$ & 320 & 45 & 24 & $1 / w$ & & Females reassigned \\
\hline
\end{tabular}


TABLE C.6 (Cont.)

\begin{tabular}{|c|c|c|c|c|c|c|c|c|}
\hline $\begin{array}{c}\text { Expt. } \\
\text { No. }\end{array}$ & $\begin{array}{l}\text { Treat- } \\
\text { ment } \\
\text { Code }\end{array}$ & $\begin{array}{l}\text { Radia- } \\
\text { tion } \\
\text { Quality }^{\mathbf{a}}\end{array}$ & $\begin{array}{l}\text { Rads } \\
\text { (total) }\end{array}$ & $\begin{array}{l}\text { Time } \\
(\min )\end{array}$ & $\begin{array}{l}\text { Frac- } \\
\text { tions }\end{array}$ & $\begin{array}{c}\text { Fraction } \\
\text { Unit } \\
\text { Time }^{\mathrm{b}}\end{array}$ & $\begin{array}{c}\text { No. of } \\
\text { Repeats }\end{array}$ & Comments \\
\hline 4 & Lo & C & 0 & 1320 & 5 & $5 / w$ & 23 & Males \\
\hline 4 & LC & C & 0 & 1320 & 5 & $5 / w$ & 59 & Males \\
\hline 4 & $\mathrm{~L} 1$ & $\mathbf{G}$ & 206 & 1320 & 5 & $5 / w$ & 23 & Males \\
\hline 4 & $\mathrm{~L} 2$ & $\mathbf{G}$ & 417 & 1320 & 5 & $5 / w$ & 23 & Males \\
\hline 4 & L3 & G & 959 & 1320 & 5 & $5 / w$ & 23 & Males \\
\hline 4 & $\mathrm{~L} 4$ & $G$ & 1918 & 1320 & 5 & $5 / w$ & 23 & Males \\
\hline 4 & L.5 & G & 529 & 1320 & 5 & $5 / w$ & 59 & Males \\
\hline 4 & L6 & $\vec{G}$ & 1070 & 1320 & 5 & $5 / w$ & 59 & Males \\
\hline 4 & L7 & $\mathrm{G}$ & 2460 & 1320 & 5 & $5 / w$ & 59 & Males \\
\hline 4 & wo & $\mathrm{C}$ & 0 & 45 & 24 & $1 / w$ & & Females; no MICROS \\
\hline 4 & W1 & G & 807 & 45 & 24 & $v_{w}$ & & Females; no MICROS \\
\hline 4 & W2 & $\bar{G}$ & 2690 & 45 & 24 & $1 / w$ & & Females; no MICROS \\
\hline 4 & W1 & $\mathbf{N}$ & 80 & 45 & 24 & $1 / w$ & & Females; no MICROS \\
\hline 4 & W2 & $\mathrm{N}$ & 240 & 45 & 24 & $1 / w$ & & Females; no MICROS \\
\hline 7 & 00 & $\mathrm{C}$ & 0 & 20 & 0 & & & \\
\hline 7 & Q1 & $\mathbf{G}$ & 417 & 45 & 60 & $1 / w$ & & MICROS of males only \\
\hline 7 & Q2 & $\mathbf{G}$ & 1918 & 45 & 60 & $v_{w}$ & & MICROS of males only \\
\hline 7 & Q1 & $\bar{N}$ & 40 & 45 & 60 & $1 / w$ & & MICROS of males only \\
\hline 7 & Q2 & $\mathbf{N}$ & 160 & 45 & 60 & $1 / w$ & & MICROS of males only \\
\hline 7 & $\mathrm{R} 1$ & $\mathrm{G}$ & 206 & 20 & 1 & & & Age at start $515 \mathrm{~d}$ \\
\hline 7 & $\mathrm{R} 2$ & $\mathrm{G}$ & 569 & 20 & 1 & & & Age at start $515 \mathrm{~d}$ \\
\hline 7 & $\mathrm{R} 1$ & $\mathbf{N}$ & 40 & 20 & 1 & & & Age at start $515 \mathrm{~d}$ \\
\hline 7 & R2 & $\mathbf{N}$ & 160 & 20 & 1 & & & Age at start $515 \mathrm{~d}$ \\
\hline 8 & UO & $\mathrm{C}$ & 0 & 45 & 999 & $1 / w$ & & $\begin{array}{l}\text { MICROS of males and } \\
\text { females }\end{array}$ \\
\hline 8 & U1 & G & 6.95 & 45 & 999 & $1 / w$ & & MICROS of males only \\
\hline 8 & U2 & G & 17.38 & 45 & 999 & $1 / w$ & & MICROS of males only \\
\hline 8 & U3 & G & 31.9 & 45 & 999 & $1 / w$ & & $\begin{array}{l}\text { Males \& a few females; } \\
\text { no MICROS }\end{array}$ \\
\hline 8 & U1 & $\mathbf{N}$ & 0.667 & 45 & 999 & $1 / w$ & & $\begin{array}{l}\text { MICROS of males and } \\
\text { females }\end{array}$ \\
\hline 8 & U2 & $\mathrm{N}$ & 1.67 & 45 & 999 & $1 / w$ & & $\begin{array}{l}\text { Males \& a few females; } \\
\text { no MICROS }\end{array}$ \\
\hline 8 & U3 & $\mathbf{N}$ & 2.67 & 45 & 999 & $1 / w$ & & $\begin{array}{l}\text { Males \& a few females; } \\
\text { no MICROS }\end{array}$ \\
\hline 9 & $\mathrm{XC}$ & C & 0 & 20 & 1 & & & Females \\
\hline 9 & $\mathbf{X O}$ & $\mathbf{C}$ & 0 & 45 & 1 & & & No MICROS \\
\hline 9 & $\mathrm{XX}$ & $\mathbf{C}$ & 0 & 45 & 24 & $1 / w$ & & Females; no MICROS \\
\hline 9 & $\mathrm{X} 1$ & $\mathrm{G}$ & 22.5 & 20 & 1 & & & Females \\
\hline 9 & $\mathbf{X} 2$ & G & 45 & 20 & 1 & & & Females \\
\hline 9 & $\mathrm{X} 3$ & G & 90 & 20 & 1 & & & Females \\
\hline 9 & $X X$ & $\mathrm{~N}$ & 10 & 45 & 24 & $1 / w$ & & Females; no MICROS \\
\hline 9 & $\mathrm{X} 2$ & $\mathrm{~N}$ & 5 & 5 & 1 & & & Females; no MICROS \\
\hline 9 & $\mathrm{X} 3$ & $\mathrm{~N}$ & 10 & 10 & 1 & & & No MICROS \\
\hline 9 & $\mathrm{X} 4$ & $\mathbf{N}$ & 1 & 20 & 1 & & & Females \\
\hline 9 & $\mathrm{X} 5$ & $\mathrm{~N}$ & 2.5 & 20 & 1 & & & Females \\
\hline 9 & $\mathrm{X} 6$ & $\mathrm{~N}$ & 5 & 20 & 1 & & & Females \\
\hline 9 & $\mathrm{X} 7$ & $\mathrm{~N}$ & 10 & 20 & 1 & & & Females \\
\hline 9 & $\mathrm{X8}$ & $\mathrm{N}$ & 20 & 20 & 1 & & & Females \\
\hline 9 & $\mathrm{X} 9$ & $\mathrm{~N}$ & 40 & 20 & 1 & & & Females \\
\hline 10 & Vo & $\mathrm{C}$ & 0 & 45 & 24 & $1 / w$ & & $\begin{array}{l}P . \text { leucopus males; } \\
\text { no MICROS }\end{array}$ \\
\hline 10 & wo & $\mathrm{C}$ & 0 & 20 & 1 & & & $\begin{array}{l}\text { P. leucopus males; } \\
\text { no MICROS }\end{array}$ \\
\hline 10 & $\mathrm{~V} 1$ & G & 90 & 20 & 1 . & & & $\begin{array}{l}\text { P. leucopus males; } \\
\text { no MICROS }\end{array}$ \\
\hline
\end{tabular}




\section{TABLE C.6 (Cont.)}

\begin{tabular}{|c|c|c|c|c|c|c|c|c|}
\hline $\begin{array}{l}\text { Expt. } \\
\text { No. }\end{array}$ & $\begin{array}{l}\text { Treat- } \\
\text { ment } \\
\text { Code }\end{array}$ & $\begin{array}{l}\text { Radia- } \\
\text { tion } \\
\text { Quality }\end{array}$ & $\begin{array}{l}\text { Rads } \\
\text { (total) }\end{array}$ & $\begin{array}{l}\text { Time } \\
(\min )\end{array}$ & $\begin{array}{l}\text { Frac- } \\
\text { tions }\end{array}$ & $\begin{array}{c}\text { Fraction/ } \\
\text { Unit } \\
\text { Time }^{b}\end{array}$ & $\begin{array}{l}\text { No. of } \\
\text { Repeats }\end{array}$ & Comments \\
\hline 10 & V2 & G & 143 & 20 & 1 & & & $\begin{array}{l}\text { P. leucopus males; } \\
\text { no MICROS }\end{array}$ \\
\hline 10 & V3 & G & 206 & 20 & 1 & & & $\begin{array}{l}\text { P. leucopus males; } \\
\text { no MICROS }\end{array}$ \\
\hline 10 & V4 & G & 417 & 20 & 1 & & & $\begin{array}{l}P . \text { leuccpus males; } \\
\text { no MICROS }\end{array}$ \\
\hline 10 & VV & $\mathbf{N}$ & 40 & 45 & 24 & $1 / w$ & & $\begin{array}{l}\text { P. leucopus males; } \\
\text { no MICROS }\end{array}$ \\
\hline 10 & V1 & $\mathrm{N}$ & 20 & 20 & 1 & & & $\begin{array}{l}\text { P. leucopus males; } \\
\text { no MICROS }\end{array}$ \\
\hline 10 & V2 & $\mathrm{N}$ & 40 & 20 & 1 & & & $\begin{array}{l}P . \text { leucopus males; } \\
\text { no MICROS }\end{array}$ \\
\hline 10 & V3 & $\mathrm{N}$ & 80 & 20 & 1 & & & $\begin{array}{l}\text { P. leucopus males; } \\
\text { no MICROS }\end{array}$ \\
\hline 10 & V4 & $\mathrm{N}$ & 160 & 20 & 1 & & & $\begin{array}{l}P . \text { leucopus males; } \\
\text { no MICROS }\end{array}$ \\
\hline 10 & VW & $\mathbf{N}$ & 160 & 45 & 24 & $1 / w$ & & $\begin{array}{l}\text { P. leucopus males; } \\
\text { no MICROS }\end{array}$ \\
\hline 12 & Jo & $\mathrm{C}$ & 0 & & 0 & & & Males; no MICROS \\
\hline 12 & J1 & $\mathrm{N}$ & 240 & 20 & 1 & $1 / w$ & & Males; no MICROS \\
\hline 12 & J2 & $\mathrm{N}$ & 240 & 20 & 2 & $1 / w$ & & Males; no MICROS \\
\hline 12 & $\mathrm{~J} 4$ & $\mathbf{N}$ & 240 & 20 & 4 & $1 / w$ & & Males; no MICROS \\
\hline 12 & J6 & $\mathbf{N}$ & 240 & 20 & 6 & $1 / w$ & & Males; no MICROS \\
\hline 13 & $\mathbf{O A}$ & $\mathrm{C}$ & 0 & 20 & 60 & $1 / w$ & & \\
\hline 13 & $\mathrm{OB}$ & $\mathrm{C}$ & 0 & 20 & 60 & $v_{w}$ & & \\
\hline 13 & OC & $\mathrm{C}$ & 0 & 20 & 60 & $1 / w$ & & \\
\hline 13 & $0 \mathrm{X}$ & $\mathrm{C}$ & 0 & 20 & 60 & $1 / w$ & & \\
\hline 13 & $1 \mathrm{~A}$ & G & 100 & 20 & 60 & $1 / w$ & & \\
\hline 13 & $1 \mathrm{~B}$ & G & 100 & 20 & 60 & $1 / w$ & & \\
\hline 13 & $1 \mathrm{C}$ & $G$ & 100 & 20 & 60 & $1 / w$ & & \\
\hline 13 & $1 \mathrm{X}$ & G & 100 & 20 & 60 & $1 / w$ & & \\
\hline 13 & $2 \mathrm{~A}$ & $\vec{G}$ & 200 & 20 & 60 & $1 / w$ & & \\
\hline 13 & $2 x$ & $\bar{G}$ & 200 & 20 & 60 & $1 / w$ & & \\
\hline 13 & $3 \mathrm{~A}$ & G & 300 & 20 & 60 & $v_{w}$ & & \\
\hline 13 & $3 X$ & $G$ & 300 & 20 & 60 & $1 / w$ & & \\
\hline 13 & $4 \mathrm{~A}$ & G & 450 & 20 & 60 & $1 / w$ & & \\
\hline 13 & $4 X$ & G & 450 & 20 & 60 & $1 / w$ & & \\
\hline 13 & $5 \mathrm{~A}$ & $G$ & 600 & 20 & 60 & $1 / w$ & & \\
\hline 13 & $5 X$ & G & 600 & 20 & 60 & $1 / w$ & & \\
\hline 13 & $1 \mathrm{~A}$ & $\mathrm{~N}$ & 2 & 20 & 60 & $1 / w$ & & \\
\hline 13 & $1 B$ & $\mathrm{~N}$ & 2 & 20 & 60 & $1 / w$ & & \\
\hline 13 & $1 \mathrm{C}$ & $\mathrm{N}$ & 2 & 20 & 60 & $1 / w$ & & \\
\hline 13 & $1 X$ & $\mathrm{~N}$ & 2 & 20 & 60 & $1 / w$ & & \\
\hline 13 & $2 \mathrm{~A}$ & $\mathrm{~N}$ & 7.5 & 20 & 60 & $1 / w$ & & \\
\hline 13 & $2 \mathrm{X}$ & $\mathrm{N}$ & 7.5 & 20 & 60 & $1 / w$ & & \\
\hline 13 & $3 \mathrm{~A}$ & $\mathrm{~N}$ & 13.5 & 20 & 60 & $1 / w$ & & \\
\hline 13 & $3 X$ & $\mathrm{~N}$ & 13.5 & 20 & 60 & $\mathrm{~V} / \mathrm{w}$ & & \\
\hline 13 & $4 \mathrm{~A}$ & $\mathrm{~N}$ & 21 & 20 & 60 & $1 / w$ & & \\
\hline 13 & $4 \mathrm{X}$ & $\mathrm{N}$ & 21 & 20 & 60 & $1 / w$ & & \\
\hline 13 & $5 \mathrm{~A}$ & $\mathrm{~N}$ & 30 & 20 & 60 & $1 / w$ & & \\
\hline 13 & $5 X$ & $\mathrm{~N}$ & 30 & 20 & 60 & $1 / w$ & & \\
\hline 13 & $6 \mathrm{~A}$ & $\mathrm{~N}$ & 40 & 20 & 60 & $1 / w$ & & \\
\hline 13 & $6 \mathrm{X}$ & $\mathrm{N}$ & 40 & 20 & 60 & $1 / w$ & & \\
\hline 14 & $\mathrm{OP}$ & $\mathrm{C}$ & 0 & 20 & 1 & & & WR2721 \\
\hline 14 & OS & $\mathrm{C}$ & 0 & 20 & 1 & & & Saline \\
\hline 14 & Co & $\mathrm{G}$ & 206 & 20 & 1 & & & No injection \\
\hline 14 & $\mathrm{CP}$ & $\mathrm{G}$ & 206 & 20 & 1 & & & WR2721 \\
\hline
\end{tabular}


TABLE C.6 (Cont.)

\begin{tabular}{|c|c|c|c|c|c|c|c|c|}
\hline $\begin{array}{c}\text { Expt. } \\
\text { No. }\end{array}$ & $\begin{array}{l}\text { Treat- } \\
\text { ment } \\
\text { Code }\end{array}$ & $\begin{array}{c}\text { Radia- } \\
\text { tion } \\
\text { Quality }^{\mathbf{a}}\end{array}$ & $\begin{array}{l}\text { Rads } \\
\text { (total) }\end{array}$ & $\begin{array}{l}\text { Time } \\
(\min )\end{array}$ & $\begin{array}{l}\text { Frac- } \\
\text { tions }\end{array}$ & $\begin{array}{c}\text { Fraction } \\
\text { Unit } \\
\text { Time }^{b}\end{array}$ & $\begin{array}{c}\text { No. of } \\
\text { Repeats }\end{array}$ & Comments \\
\hline 14 & DP & G & 417 & 20 & 1 & & & WR2721 \\
\hline 14 & AO & $\mathbf{N}$ & 10 & 20 & 1 & & & No injection \\
\hline 14 & $\mathbf{A P}$ & $\mathbf{N}$ & 10 & 20 & 1 & & & WR2721 \\
\hline 14 & $\mathbf{A R}$ & $\mathbf{N}$ & 10 & 20 & 1 & & & WR151327 \\
\hline 14 & $\mathrm{BP}$ & $\mathbf{N}$ & 40 & 20 & 1 & & & WR2721 \\
\hline 14 & $\mathrm{BR}$ & $\mathrm{N}$ & 40 & 20 & 1 & & & WR151327 \\
\hline
\end{tabular}

a $\mathrm{C}=$ control; $\mathrm{G}=\gamma$ ray; $\mathrm{N}=$ neutron.

b $\mathbf{w}=$ week; $\mathrm{m}=$ month. 


\section{DISTRIBUTION FOR ANL-94/26}

\section{Internal}

ANL Technical Publications Services

D.E. Nadziejka (8)

N. Clodi (2)

B.A. Carnes (100)

\section{External}

U.S. Department of Energy Office of Scientific and Technical Information (12) Manager, U.S. Department of Energy Chicago Field Office ANL-E Libraries (2) ANL-W Library 

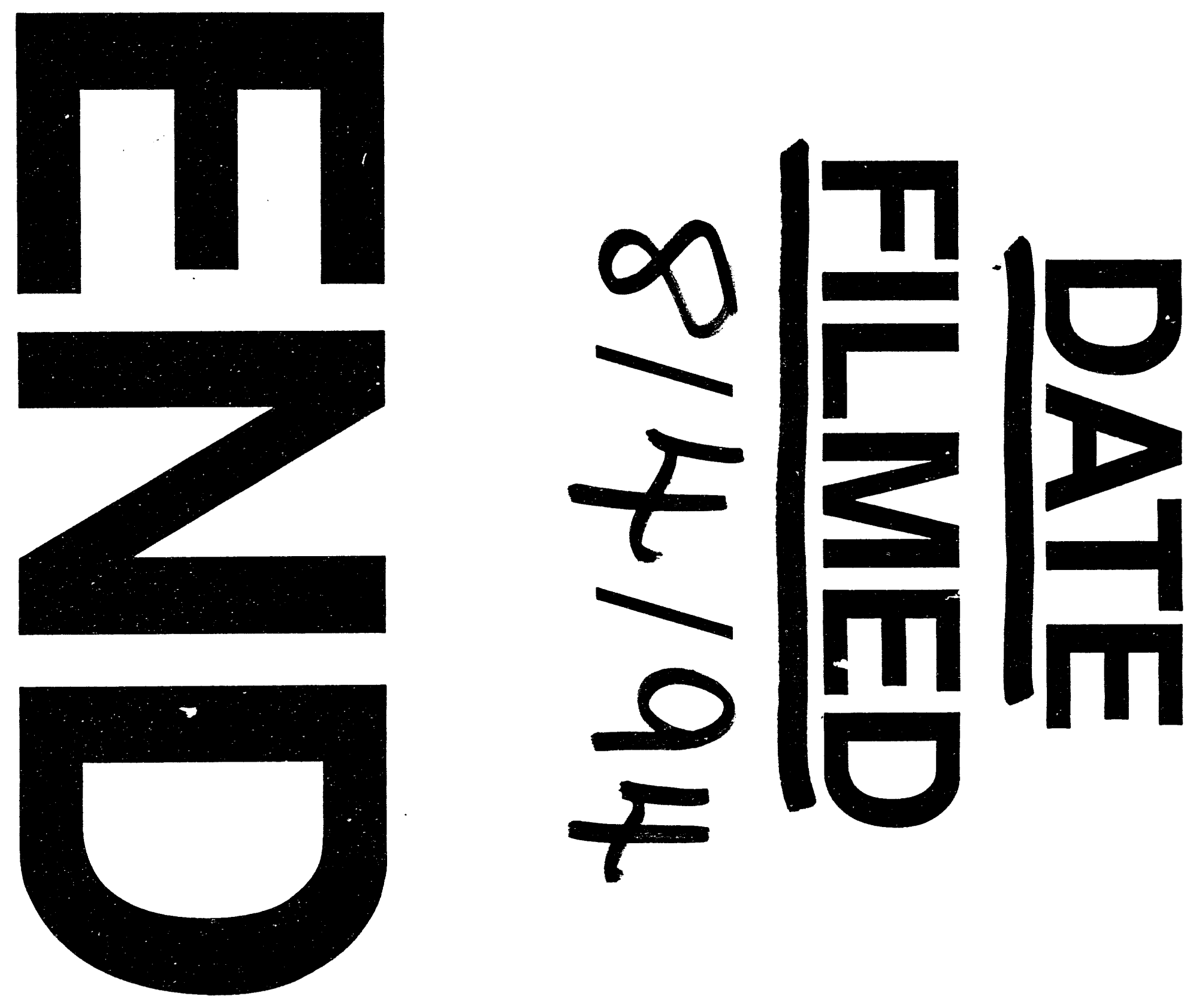


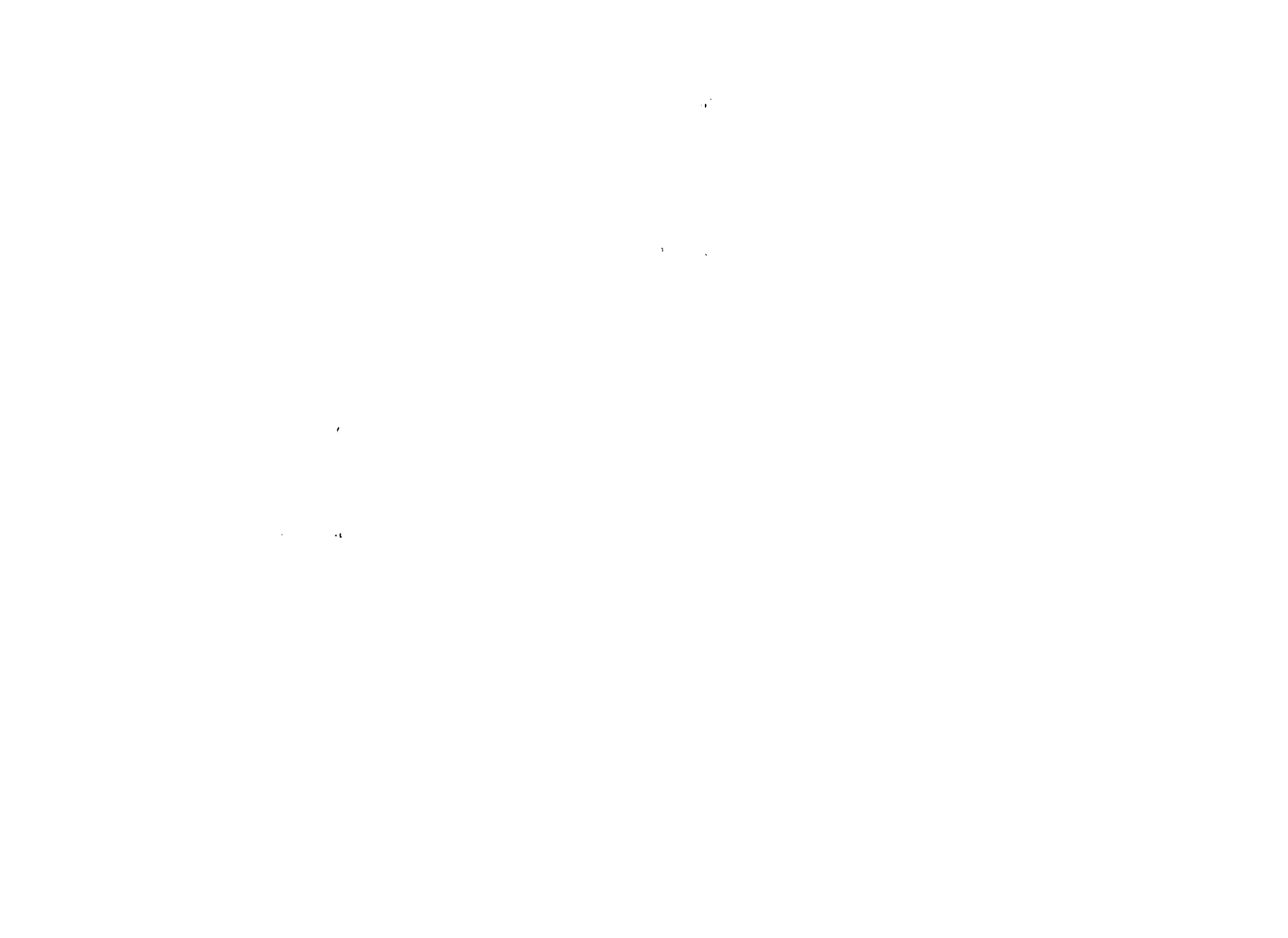

